\title{
Plumularioid hydroids (Cnidaria: Hydrozoa) from off New Caledonia collected during KANACONO and KANADEEP expeditions of the French Tropical Deep-Sea Benthos Program
}

\author{
Horia R. GALEA ${ }^{1, *} \&$ Davide MAGGIONI ${ }^{2}$ \\ ${ }^{1}$ Hydrozoan Research Laboratory, 405 Chemin Les Gatiers, 83170 Tourves, France. \\ ${ }^{2}$ Università degli Studi di Milano-Bicocca, Dipartimento di Scienze dell'Ambiente e della Terra, \\ Piazza della Scienza 1, 20126 Milano, Italy. \\ ${ }^{2}$ Università degli Studi di Milano-Bicocca, Marine and High Education (MaRHE) Center, 12030 Faafu \\ Magoodhoo, Republic of the Maldives. \\ *Corresponding author: horia.galea@gmail.com \\ 2Email: davide.maggioni@unimib.it

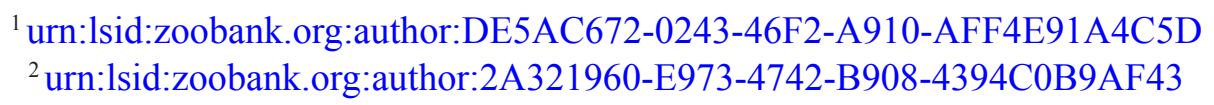

\begin{abstract}
This study reports on 25 species of hydroids occurring in the collections gathered during KANACONO and KANADEEP expeditions carried out in the SE of New Caledonia in 2016, and off the western coast of the island in 2017, respectively. Of these, 19 have not been dealt with in earlier reports on these collections. Two new genera and four new species are described, viz, Actinopluma mirifica Galea gen. et sp. nov., provisionally assigned to the family Kirchenpaueriidae Stechow, 1921, Schizoplumularia helicoidalis sp. nov., belonging to the Plumulariidae McCrady, 1859, and Corhiza patula Galea sp. nov. and Thamnopteros uniserius Galea gen. et sp. nov., both placed in the family Halopterididae Millard, 1962. The gonotheca and the medusoid gonophore of Plumularia contraria Ansín Agís et al., 2014 are described for the first time, allowing a genus transfer to Dentitheca Stechow, 1919, as D. contraria comb. nov. Plumularia conjuncta Billard, 1913, known earlier from a minute portion of colony, is redescribed based on a complete, though infertile, specimen. Similarly, complete specimens corresponding to the hydroid previously referred to as Antennella megatheca Ansín Agís et al., 2009 are documented, allowing a provisional reallocation to Corhiza Millard, 1962 and a description of its so far unknown gonothecae. Fertile material assignable to the poorly-known Monostaechas fisheri Nutting, 1905 allows the recognition of this hydroid as a valid species, distinct from M. quadridens (McCrady, 1859). Most taxa are illustrated to validate the reliability of their identifications. Finally, phylogenetic reconstructions of the families Aglaopheniidae, Plumulariidae, and Halopterididae, based on the 16S rRNA, allowed a first genetic characterization of some of the species dealt with in this work.
\end{abstract}

Keywords. Deep water, Leptothecata, taxonomy, new species.

Galea H.R. \& Maggioni D. 2020. Plumularioid hydroids (Cnidaria: Hydrozoa) from off New Caledonia collected during KANACONO and KANADEEP expeditions of the French Tropical Deep-Sea Benthos Program. European Journal of Taxonomy 708: 1-58. https://doi.org/10.5852/ejt.2020.708 


\section{Introduction}

This is the third report of a developing series of papers dealing with the hydroids collected during the KANACONO (2016) and KANADEEP (2017) expeditions of the French Tropical Deep-Sea Benthos Program.

Earlier reports (Galea \& Schuchert 2019; Galea 2020) dealt with hydroids belonging to various families, viz, Staurothecidae Maronna et al., 2016, Syntheciidae Marktanner-Turneretscher, 1890, Sertulariidae Lamouroux, 1812, Sertularellidae Maronna et al., 2016, Symplectoscyphidae Maronna et al., 2016, Thyroscyphidae Stechow, 1920, Zygophylacidae Quech, 1885 and Aglaopheniidae MarktannerTurneretscher, 1890.

Several lots containing aglaopheniid hydroids were omitted from a previous study (Galea 2020). Thus, the present report focuses again, though very succinctly, on the family Aglaopheniidae, and discusses in detail taxa belonging to the families Kirchenpaueriidae Stechow, 1921, Plumulariidae McCrady, 1859 and Halopterididae Millard, 1962, not studied so far.

\section{Material and methods}

Study methods were described in Galea $(2007,2008)$. Station numbers, as indicated in the text, are preceded by a two-letter prefix referring to the sampling gear used to secure the material, either a beam trawl (CP), a rocky bottom dredge (DR) or a Warrén dredge (DW). The material, fixed and preserved in ethanol, is deposited in the collections of the Muséum national d'histoire naturelle (MNHN) of Paris, France, and catalogue numbers are indicated as MNHN-IK-2015- followed by 3-digit numbers. Fragments, cut off from some specimens with sufficient coenosarc, were used to extract DNA. Comparison material, in the private collection of the author, is designated by HRG- followed by 4-digit numbers.

The total genomic DNA of ethanol-fixed hydrozoans was extracted following a protocol modified from Zietara et al. (2000) or using the Qiagen DNeasy Blood and Tissue kit. Notably, despite several attempts, it was not possible to obtain usable DNA from some of the ethanol-fixed samples (e.g., the holotype of Schizoplumularia helicoidalis sp. nov., MNHN-IK-2015-610) and these specimens could not be included in genetic analyses. When DNA extractions were successful, a portion of the mitochondrial 16S rRNA was amplified using the primers and protocols described in Cunningham \& Buss (1993). All PCR products were checked through electrophoretic runs in 1.5\% agarose gels, purified, and sequenced using ABI 3730xl DNA Analyzer (Applied Biosystems). Geneious ver. 6.1.6 was used to visually check and assemble the obtained sequences, which were then deposited in GenBank (accession numbers: MT655138-MT655156).

Prior to conduct phylogenetic analyses, all available 16S sequences for the families Aglaopheniidae (1065 sequences), Halopterididiae (254 sequences), and Plumulariidae (328 sequences) were downloaded (last accessed 29 June 2020) from GenBank to assemble three family-level separate datasets.

Sequences in each dataset were aligned with MAFFT 7.110 (Katoh \& Standley 2013), using the E-INS-i option. Appropriate evolutionary models were determined using the Akaike Information Criterion with jModelTest 2 (Darriba et al. 2012) and resulted as GTR $+\mathrm{I}+\mathrm{G}$ for all datasets.

Phylogenetic inference analyses were performed using Bayesian inference and maximum likelihood, as described in Maggioni et al. (2020). Subsequently, analyses were re-run on reduced datasets, after removing ambiguously identified species and keeping two sequences per species. All analyses were run on the CIPRES server (Miller et al. 2010). 


\section{Results}

\section{Systematic account}

Class Hydrozoa Owen, 1843

Subclass Hydroidolina Collins, 2000

Order Leptothecata Cornelius, 1992

Family Aglaopheniidae Marktanner-Turneretscher, 1890

Genus Aglaophenia Lamouroux, 1812

Aglaophenia digitulus Vervoort \& Watson, 2003

Figs 1, 2A-H

Aglaophenia digitulus Vervoort \& Watson, 2003: 271, fig. 64a-e.

\section{Material examined}

PACIFIC OCEAN - 1 ca $30 \mathrm{~cm}$ high, sterile colony; off New Caledonia, stn DW4703; $22^{\circ} 46^{\prime} \mathrm{S}$,

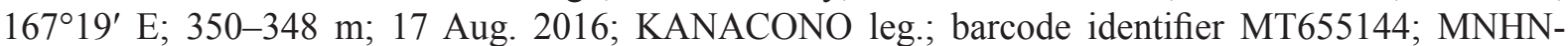
IK-2015-569 • a fully fertile colony ca $31 \mathrm{~cm}$ high; off New Caledonia, stn CP4739; $22^{\circ} 41^{\prime} \mathrm{S}, 167^{\circ} 41^{\prime} \mathrm{E}$; 393-358 m; 22 Aug. 2016; KANACONO leg.; barcode identifier MT655146; MNHN-IK-2015-578 •

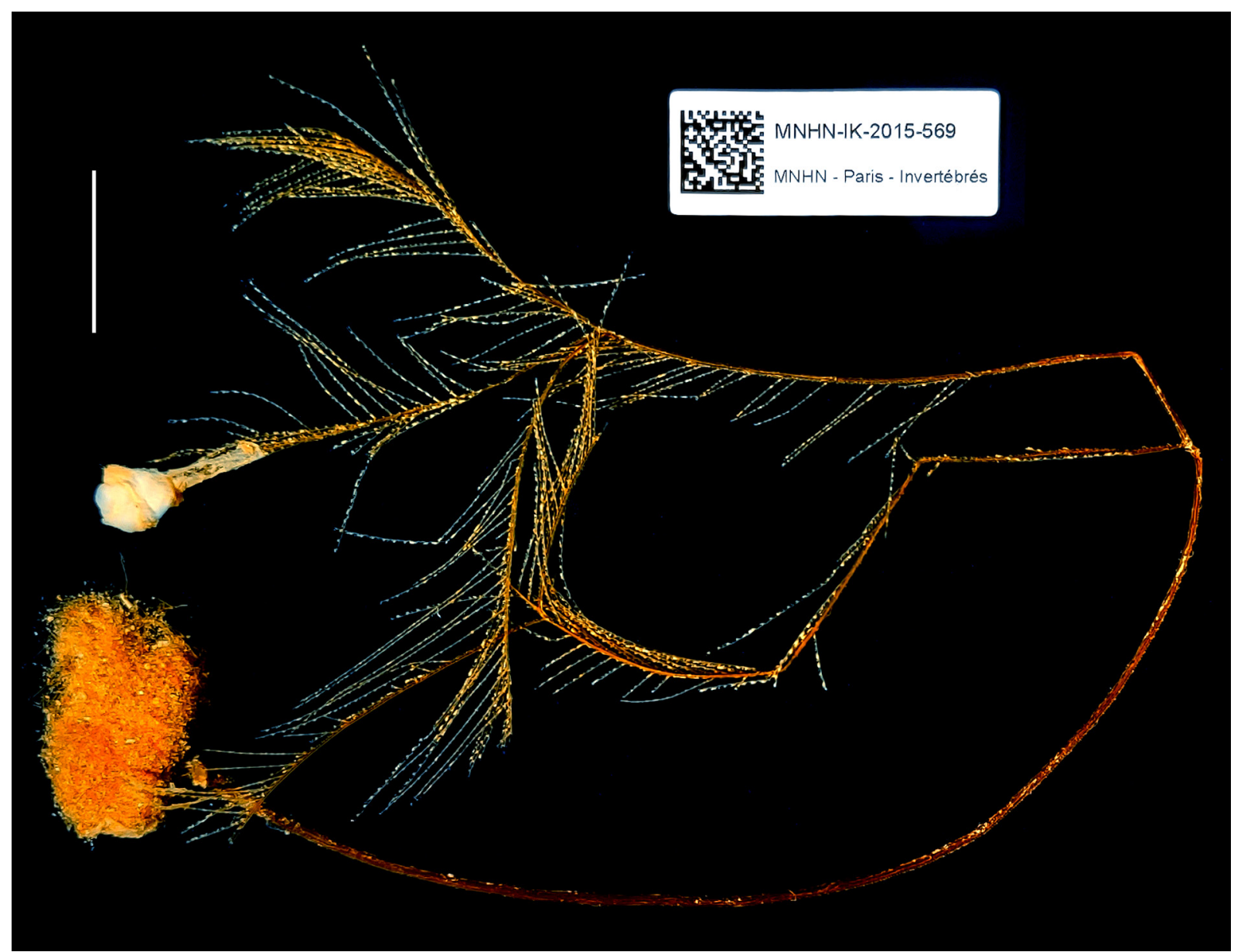

Fig. 1. Aglaophenia digitulus Vervoort \& Watson, 2003, colony from sample MNHN-IK-2015-569. Scale bar: $2 \mathrm{~cm}$. 


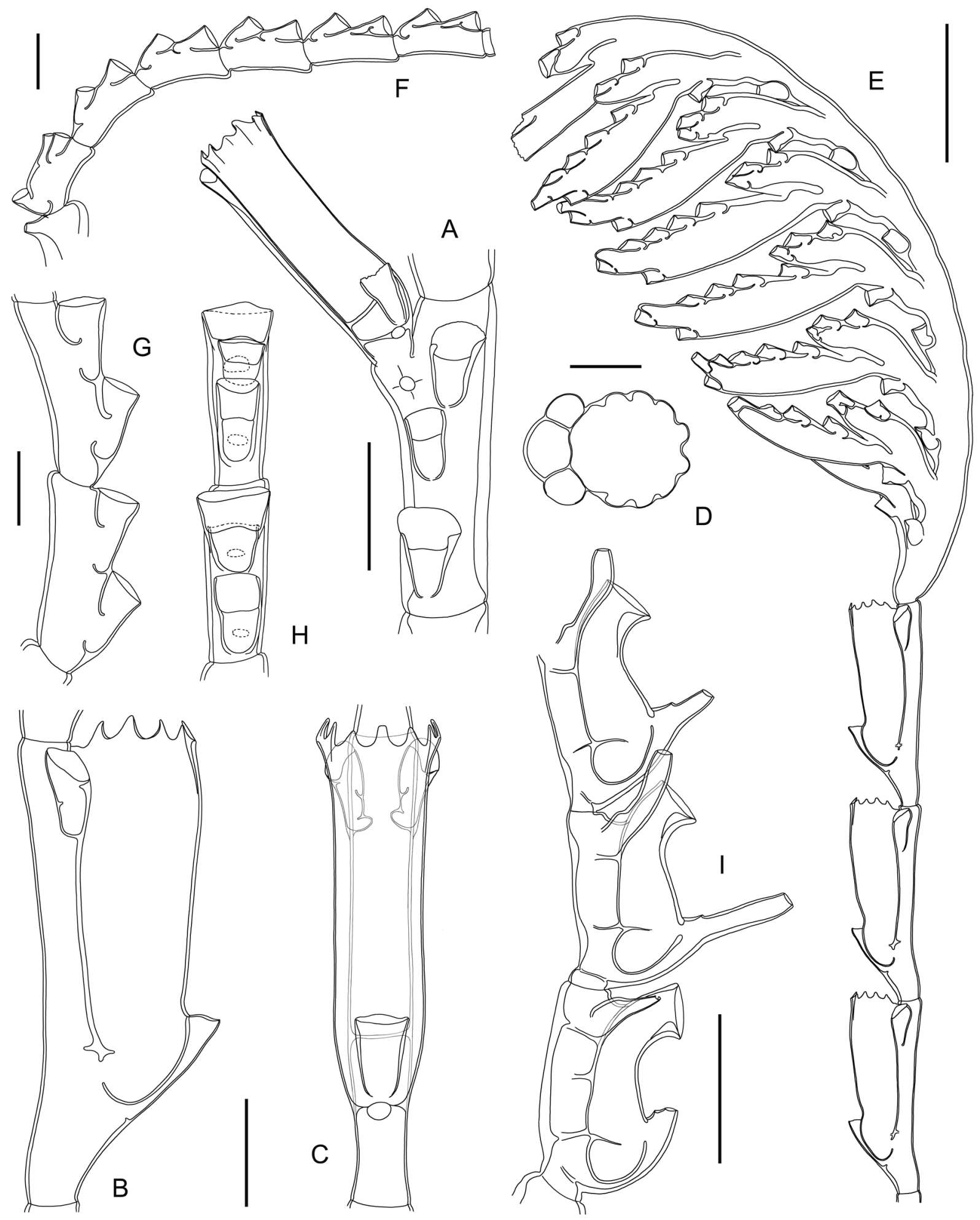

Fig. 2. A-H. Aglaophenia digitulus Vervoort \& Watson, 2003, stem internode from monosiphonic part (A); hydrotheca in lateral (B), frontal (C) and apical (D) views; modified, distal part of a cladium with corbula $(\mathrm{E})$; pseudophylactocarp $(\mathrm{F})$ and details in lateral $(\mathrm{G})$ and frontal $(\mathrm{H})$ aspects; A, E-H from sample MNHN-IK-2015-578; B-D from sample MNHN-IK-2015-569. - I. Taxella gracilicaulis (Jäderholm, 1903), three cormidia from sample MNHN-IK-2015-571. Scale bars: A $=500 \mu \mathrm{m}$; B-C, $\mathrm{F}=300 \mu \mathrm{m} ; \mathrm{D}, \mathrm{G}-\mathrm{I}=200 \mu \mathrm{m} ; \mathrm{E}=1 \mathrm{~mm}$. 
two sterile colonies, 18 and $23 \mathrm{~cm}$ high, the former without hydrorhiza; off New Caledonia, stn CP4676; $22^{\circ} 51^{\prime} \mathrm{S}, 167^{\circ} 30^{\prime} \mathrm{E}$; 383-383 m; 13 Aug. 2016; KANACONO leg.; barcode identifier MT655147; MNHN-IK-2015-579.

\section{Remarks}

The specimens at hand conform strictly to the original description by Vervoort \& Watson (2003). However, no mention was made by these authors as to the occurrence of pseudophylactocarps, as noted in the present specimens (Fig. 2F-H). These ca $5 \mathrm{~mm}$ long, curled structures replace some hydrocladia either on the proximal parts of side branches or on the main stem before it branches; like the cladia, the pseudophylactocarps are borne on the same apophyses, and are composed of a succession of short internodes that possibly represent vestigial hydrothecae, together with their corresponding mesial nematothecae.

\section{Distribution}

Kermandec Islands (Vervoort \& Watson 2003), New Caledonia (present study).

Aglaophenia howensis Briggs, 1918

Aglaophenia howensis - Galea, 2020: figs 1a-b, 2.

\section{Material examined}

PACIFIC OCEAN - five colonies and fragments, $8.5-18 \mathrm{~cm}$ high, largest one bearing gonothecae; off New Caledonia, stn CP4787; 22 ${ }^{\circ} 43^{\prime}$ S, $167^{\circ} 43^{\prime}$ E; 500-533 m; 29 Aug. 2016; KANACONO leg.; MNHN-IK-2015-563 - 1 ca 9 cm high, sterile cormoid; off New Caledonia, stn DW4737; 22 ${ }^{\circ} 45^{\prime}$ S, 167²' E; 387-456 m; 22 Aug. 2016; KANACONO leg.; MNHN-IK-2015-564 • 1 ca 9 cm high, sterile cormoid; off New Caledonia, stn DW4736; 22 ${ }^{\circ} 42^{\prime}$ S, $167^{\circ} 41^{\prime}$ E; 303-308 m; 22 Aug. 2016; KANACONO leg.; MNHN-IK-2015-565.

\section{Remarks}

This species was recently dealt with by Galea (2020).

\section{Distribution}

Scattered records from the Tasman Sea area, up to Norfolk Island in the north; New Caledonia (Galea 2020).

Genus Cladocarpus Allman, 1874

Cladocarpus keiensis Schuchert, 2003

Cladocarpus keiensis - Galea, 2020: 9, figs 1f, 5.

\section{Material examined}

PACIFIC OCEAN • 1 ca $40 \mathrm{~cm}$ high, sterile colony; off New Caledonia, stn CP4779; $23^{\circ} 02^{\prime} \mathrm{S}, 168^{\circ} 17^{\prime} \mathrm{E}$; 270-293 m; 28 Aug. 2016; KANACONO leg.; barcode identifier MT655138; MNHN-IK-2015-547.

\section{Remarks}

For a description and additional notes on this species, see Schuchert (2003) and Galea (2020), respectively, both providing comprehensive illustrations.

\section{Distribution}

Indonesia, New Caledonia (Galea 2020). 
Cladocarpus pennatus Galea, 2020

Cladocarpus pennatus Galea, 2020: 14, figs 6c-e, 8-9.

\section{Material examined}

PACIFIC OCEAN • several $\hat{\partial}$, 9 or sterile colonies, 8-12 cm high; off New Caledonia, stn DW4711; $22^{\circ} 47^{\prime} \mathrm{S}, 167^{\circ} 24^{\prime}$ E; 335-338 m; 18 Aug. 2016; KANACONO leg.; barcode identifier MT655140; MNHN-IK-2015-549 • 2 sterile colonies, ca 12 and $14 \mathrm{~cm}$ high, respectively; off New Caledonia, stn DW4749; 233'ㅇ S, 167²4' E; 457-440 m; 24 Aug. 2016; KANACONO leg.; MNHN-IK-2015-550 • many colonies and fragments, 4-10 cm high, some sterile, others with $\delta^{\lambda}$ or $q$ gonothecae; off New Caledonia, stn DW4714; 22 $2^{\circ} 9^{\prime} \mathrm{S}, 167^{\circ} 25^{\prime} \mathrm{E}$; 394-443 m; 18 Aug. 2016; KANACONO leg.; barcode identifier MT655141; MNHN-IK-2015-551 • 2 sterile colonies, 7 and $11 \mathrm{~cm}$ high; off New Caledonia, stn DW4744; 22 $2^{\circ} 55^{\prime}$ S, $167^{\circ} 37^{\prime}$ E; 310-290 m; 23 Aug. 2016; KANACONO leg.; MNHN-IK-2015-552 • 4 colonies, ca $11 \mathrm{~cm}$ high, of which one is sterile, two bear ${ }^{\lambda}$ and one 9 gonothecae; off New Caledonia, stn CP4676; 22 $2^{\circ} 1^{\prime} \mathrm{S}, 167^{\circ} 30^{\prime}$ E; 383-383 m; 13 Aug. 2016; KANACONO leg.; MNHN-IK-2015-553 • several colonies, $8-15 \mathrm{~cm}$ high, either sterile or with ${ }^{-}$or 9 gonothecae; off New Caledonia, stn DW4743; $22^{\circ} 52^{\prime} \mathrm{S}, 167^{\circ} 34^{\prime} \mathrm{E}$; 380-340 m; 23 Aug. 2016; KANACONO leg.; MNHN-IK-2015-554 • 5 colonies, $8-12 \mathrm{~cm}$ high, one sterile, one bearing $\rho$ and three others $\widehat{\jmath}$ gonothecae; off New Caledonia, stn DW4715; $22^{\circ} 50^{\prime} \mathrm{S}, 1^{\circ} 7^{\circ} 27^{\prime} \mathrm{E}$; 424-424 m; 18 Aug. 2016; KANACONO leg.; barcode identifier MT655142; MNHN-IK-2015-555 1 ca $14 \mathrm{~cm}$ high + colony; off New Caledonia, stn CP4787; 22 $43^{\prime}$ S, $167^{\circ} 43^{\prime}$ E; 500-533 m; 29 Aug. 2016; KANACONO leg.; MNHN-IK-2015-556 • several colonies 4.5-19 cm high, either sterile or with ${ }^{\prime}$ or 9 gonothecae; off New Caledonia, stn DW4742; 22 ${ }^{\circ} 53^{\prime} \mathrm{S}, 167^{\circ} 37^{\prime} \mathrm{E}$; 290 $345 \mathrm{~m}$; 23 Aug. 2016; KANACONO leg.; MNHN-IK-2015-557 • 1 ca $7.5 \mathrm{~cm}$ high, sterile colony; off

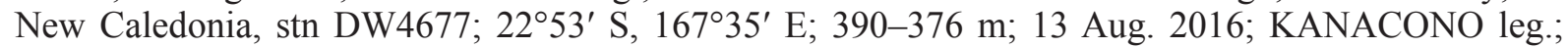
MNHN-IK-2015-558 4 colonies, 6-11 cm high, of which two bear ô gonothecae; off New Caledonia, stn DW4745; 22 ${ }^{\circ} 7^{\prime}$ S, $167^{\circ} 39^{\prime}$ E; 310-403 m; 23 Aug. 2016; KANACONO leg.; MNHN-IK-2015-559• $1 \mathrm{ca} 12.5 \mathrm{~cm}$ high colony with 9 gonothecae; off New Caledonia, stn DW4781; 22 $57^{\prime} \mathrm{S}, 1^{\circ} 67^{\circ} 47^{\prime} \mathrm{E}$; 295-255 m; 29 Aug. 2016; KANACONO leg.; MNHN-IK-2015-560 • many colonies up to $20 \mathrm{~cm}$ high, some bearing + gonothecae; off New Caledonia, stn DW4741; 22 ${ }^{\circ} 52^{\prime} \mathrm{S}, 167^{\circ} 41^{\prime} \mathrm{E}$; 210-210 m; 23 Aug. 2016; KANACONO leg.; MNHN-IK-2015-561.

\section{Remarks}

This species was recently described by Galea (2020).

\section{Distribution}

Known only from off New Caledonia (Galea 2020).

Genus Gymnangium Hincks, 1874

Gymnangium expansum (Jäderholm, 1903)

Gymnangium expansum - Galea, 2020: 19, fig. 10.

\section{Material examined}

PACIFIC OCEAN - 1 ca $17 \mathrm{~cm}$ high, fully fertile colony; off New Caledonia, stn DW4768; $23^{\circ} 25^{\prime} \mathrm{S}, 168^{\circ} 01^{\prime} \mathrm{E}$; 180-210 m; 27 Aug. 2016; KANACONO leg.; barcode identifier MT655148; MNHN-IK-2015-580.

\section{Remarks}

This species was recently dealt with by Galea (2020).

\section{Distribution}

Scattered records from the tropical and subtropical Indian and Pacific oceans, from Zanzibar to New Caledonia (Galea 2020). 
GALEA H.R. \& MAGGIONI D., Plumularioid hydroids from off New Caledonia

Genus Lytocarpia Kirchenpauer, 1872

Lytocarpia pilosa Galea, 2020

Lytocarpia pilosa Galea, 2020: 28, figs 12d-f, 14.

\section{Material examined}

PACIFIC OCEAN -1 fertile colony broken into two pieces: lower part $6 \mathrm{~cm}$ high, upper part $8.5 \mathrm{~cm}$ high; off New Caledonia, stn CP4673; 22 ${ }^{\circ} 47^{\prime} \mathrm{S}, 1^{6} 7^{\circ} 27^{\prime} \mathrm{E}$; 285-244 m; 13 Aug. 2016; KANACONO leg.; MNHN-IK-2015-562 - $1 \mathrm{ca} 20 \mathrm{~cm}$ high, fertile colony; off New Caledonia, stn CP4687; 22 ${ }^{\circ} 29^{\prime}$ S, 167³0' E; 256-268 m; 14 Aug. 2016; KANACONO leg.; MNHN-IK-2015-570.

\section{Remarks}

This species was recently described by Galea (2020).

\section{Distribution}

Known only from off New Caledonia (Galea 2020).

Genus Macrorhynchia Kirchenpauer, 1872

Macrorhynchia phoenicea (Busk, 1852)

Macrorhynchia phoenicea - Galea, 2020: 37, figs 16c-d, 18a.

\section{Material examined}

PACIFIC OCEAN - 1 ca $11.5 \mathrm{~cm}$ high, sterile colony; off New Caledonia, stn DW4741; 22 $52^{\prime} \mathrm{S}$, 16741' E; 210-210 m; 23 Aug. 2016; KANACONO leg.; MNHN-IK-2015-572 • $1 \mathrm{ca} 6 \mathrm{~cm}$ high, fertile colony; off New Caledonia, stn CP4786; 2246' S, 16742' E; 350-469 m; 29 Aug. 2016; KANACONO leg.; MNHN-IK-2015-593.

\section{Remarks}

This species was recently dealt with by Galea (2020).

\section{Distribution}

Widespread in the tropical parts of the Indian and southern Pacific oceans (Di Camillo et al. 2009).

Genus Taxella Allman, 1874

Taxella gracilicaulis (Jäderholm, 1903)

Fig. 2I

Taxella gracilicaulis - Ronowicz et al., 2017: 19, figs 7b, 9.

\section{Material examined}

PACIFIC OCEAN - several colonies, 5.5-20 cm high, some with gonothecae; off New Caledonia,

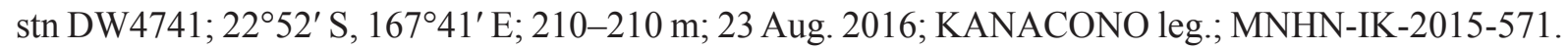

\section{Remarks}

For a synonymy, a recent redescription and taxonomical notes, refer to Ronowicz et al. (2017). Good illustrations are to be found elsewhere: for the general appearance of the colony, see Jäderholm (1903, as Lytocarpus gracilicaulis), and for microscopic details Hirohito (1995, as Halicetta gracilicaulis). Its 
systematic affinities with Taxella eximia (Allman, 1874) are unsettled yet, as revealed by analyses with molecular markers (Ronowicz et al. 2017; Moura et al. 2018), and both may prove conspecific.

\section{Distribution}

South Africa (Millard 1975), Red Sea (Vervoort 1967), Indonesia (Billard 1913), Korea (Rho 1969), Japan (Jäderholm 1903; Hirohito 1995), Australia (Watson 1997).

Family Kirchenpaueriidae Stechow, 1921

Genus Actinopluma Galea gen. nov. urn:lsid:zoobank.org:act:5CD7421D-F5D7-4AE5-8CC7-4C13AAD95F1D

\section{Type species}

Actinopluma mirifica Galea gen. et sp. nov., designated herein (see below).

\section{Diagnosis}

Hydroids with upright, rigid, coplanar colonies with sparingly-branched stem; stem and branches fascicled. Main tube of the stem undivided, but equivalents of internodes with a lateral apophysis and a number of nematothecae above; apophyses alternate, coplanar, each with a mamelon, continued directly into a main hydrocladium; two accessory cladia, projecting outward and slightly upward, are given off laterally from below both sides of the mamelon; main hydrocladium divided into internodes with hydroand nematothecae; accessory cladia shorter and thinner than main counterpart, generally composed of nematothecae-bearing internodes, occasionally with 1-2 intervening hydrothecate internodes distally. Hydrothecae cup-shaped, without associated nematothecae. Gonothecae unknown.

\section{Etymology}

From Ancient Greek ' $\dot{\alpha} \kappa \tau i \varsigma$ ', meaning 'ray', and Latin 'plūma', meaning 'plume', to describe the radiate appearance of this new hydroid genus. The gender is feminine.

\section{Remarks}

Based on morphological grounds alone, the absence of lateral nematothecae flanking the hydrotheca place this genus in the family Kirchenpaueriidae Stechow, 1921. This allocation should be regarded as provisional, pending the collection of additional material suitable for molecular studies, expected to clarify unambiguously its systematic position.

In having hydrocladia provided with two accessory appendages, the colonies of this so far monotypic genus somehow resemble macroscopically Oswaldella Stechow, 1919, but in the latter, the hydrocladia branch dichotomously at the level of the proximalmost internode, the original cladium not extending beyond this internode (Peña Cantero et al. 1997).

Actinopluma mirifica Galea gen. et sp. nov.

urn:lsid:zoobank.org:act:3C5853F3-E9EB-421B-B725-A5B5C3EDAA9B

Figs 3-5; Table 1

\section{Diagnosis}

Colony erect, rigid, coplanar, with sparingly branched stem; stem and branches fascicled. Accessory tubes with a row of nematothecae along their length. Main tube of the stem undivided, but equivalents of internodes with indistinct cladial apophysis and a row of 3 bithalamic nematothecae above; apophyses alternate along the stem, the two rows coplanar; each with a conspicuous conical mamelon with broad, rounded aperture, and a bithalamic nematotheca a short distance below to it; no delimitation between cladium and apophysis; cladia irregularly divided into hydrothecate internodes by transverse nodes; each internode with 1-4 hydrothecae and a number of nematothecae in a row between them; each 
cladium accompanied by 2 comparatively slender, accessory cladia given off from below each side of the basal mamelon; accessory cladia generally composed of successive nematothecate internodes of varied length (nodes transverse); occasionally internodes with 1-2 comparatively smaller hydrothecae intervene distally. Gonothecae unknown.

\section{Etymology}

From Latin 'mirifificus, - $a$, -um', meaning 'marvelous', to qualify the existence of such a peculiar, uncommon hydroid species.

\section{Material examined}

\section{Holotype}

PACIFIC OCEAN - 1 ca $14.5 \mathrm{~cm}$ high, sterile colony; off New Caledonia, stn CP4956; 23 $13^{\prime} \mathrm{S}$, 159³5’ E; 295-295 m; 6 Sep. 2017; KANADEEP leg.; MNHN-IK-2015-612.

\section{Paratype}

PACIFIC OCEAN - $1 \mathrm{ca} 11 \mathrm{~cm}$ high, sterile colony; off New Caledonia, stn DW4953; $24^{\circ} 10^{\prime} \mathrm{S}$, 15941’ E; 320-270 m; 5 Sep. 2017; KANADEEP leg.; MNHN-IK-2015-613.

\section{Description}

Colony erect, ca $14.5 \mathrm{~cm}$ high, rigid, coplanar, arising from rhizoid stolon anchoring it in marine sediment; stem with 2 unbranched side branches, all coplanar and fascicled; accessory tubes with longitudinal row of nematothecae. Monosiphonic parts of stem and branches undivided, but equivalents of internodes with cladial apophysis and 3 nematothecae above, on same side as apophysis; apophyses alternate along stem, two rows coplanar; apophysis with quite distant, conspicuous conical mamelon on upper side, with rounded aperture on summit, and proximal, bithalamic nematotheca; no delimitation between apophysis and cladium; two accessory cladia are given off at acute angles from the lateral sides of apophysis, insertion sites below the mamelon; all three cladia unbranched, pointing out- and upwards, pair of accessory cladia forming comparatively more acute angle with stem than with their main counterpart. Main cladium relatively thick, up to $7 \mathrm{~mm}$ long, irregularly divided into hydrothecate internodes by means of transverse nodes; each internode with 1-4 hydrothecae and a number of nematothecae in row between them; accessory cladia, up to $3.5 \mathrm{~mm}$ long, comparatively thinner than their main counterpart, comprising generally a succession of nematothecate internodes (nodes transverse) of varied length, each bearing 1-8 alternate nematothecae, slightly displaced laterally with respect to longitudinal axis of internode; more distal parts of longest accessory cladia with 1 , occasionally 2 , intervening hydrothecate internodes. Hydrothecae shallow, fully adnate adaxially to their corresponding internodes, abaxial wall with thickened perisarc; conspicuous perisarc plug at junction between adaxial wall with basis; belt of desmocytes close to basis; no nematothecae directly associated to hydrotheca. Hydranths missing, only remains of coenosarc present. Gonothecae absent.

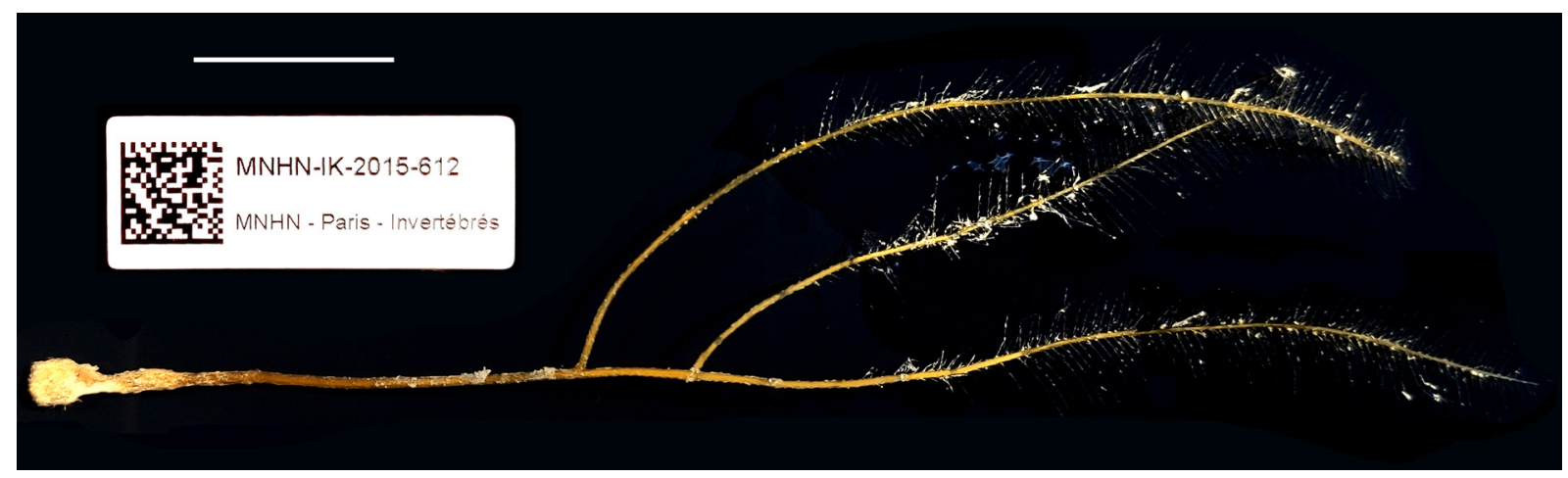

Fig. 3. Actinopluma mirifica Galea gen. et sp. nov., holotype colony, MNHN-IK-2015-612. Scale bar: $2 \mathrm{~cm}$. 


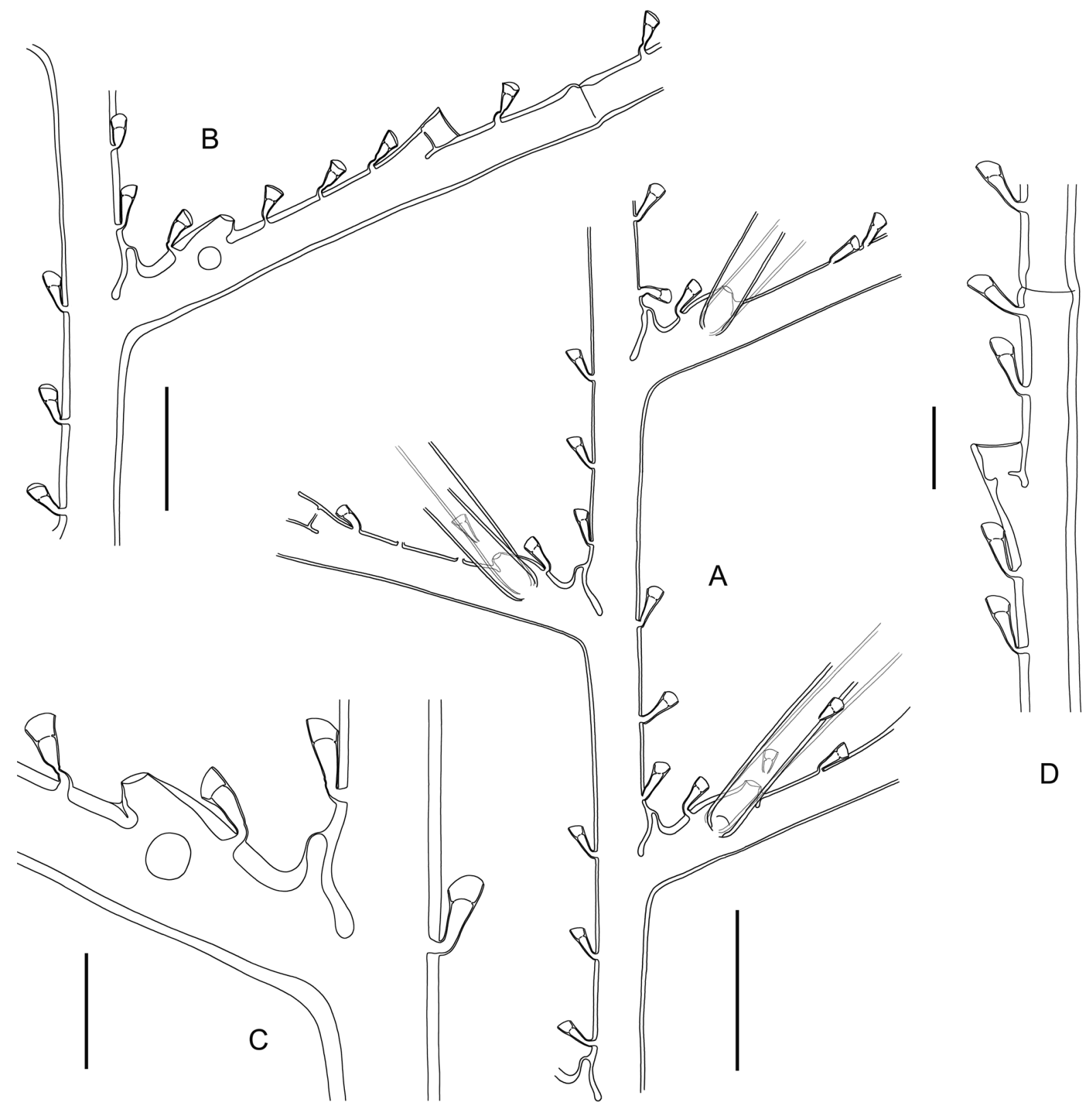

Fig. 4. Actinopluma mirifica Galea gen. et sp. nov., distalmost, monosiphonic portion of stem with three successive cladial apophyses (A); portion of monosiphonic stem with proximalmost part of a cladium (B); detail of the axil (C); portion of main cladium with hydro- and nematothecae (D); all from holotype MNHN-IK-2015-612. Scale bars: A $=300 \mu \mathrm{m}$; $\mathrm{B}=200 \mu \mathrm{m}$; C-D $=100 \mu \mathrm{m}$.

Fig. 5 (opposite page). Actinopluma mirifica Galea gen. et sp. nov., main cladium with couple of accessory counterparts (A); proximal portion of another main cladium (B), accessory cladia not shown; middle portion of a cladium with aberrant branching $(\mathrm{C})$; accessory cladium with nematothecate internodes and intervening hydrothecate internode (D); all from holotype MNHN-IK-2015-612. Scale bar: $300 \mu \mathrm{m}$. 

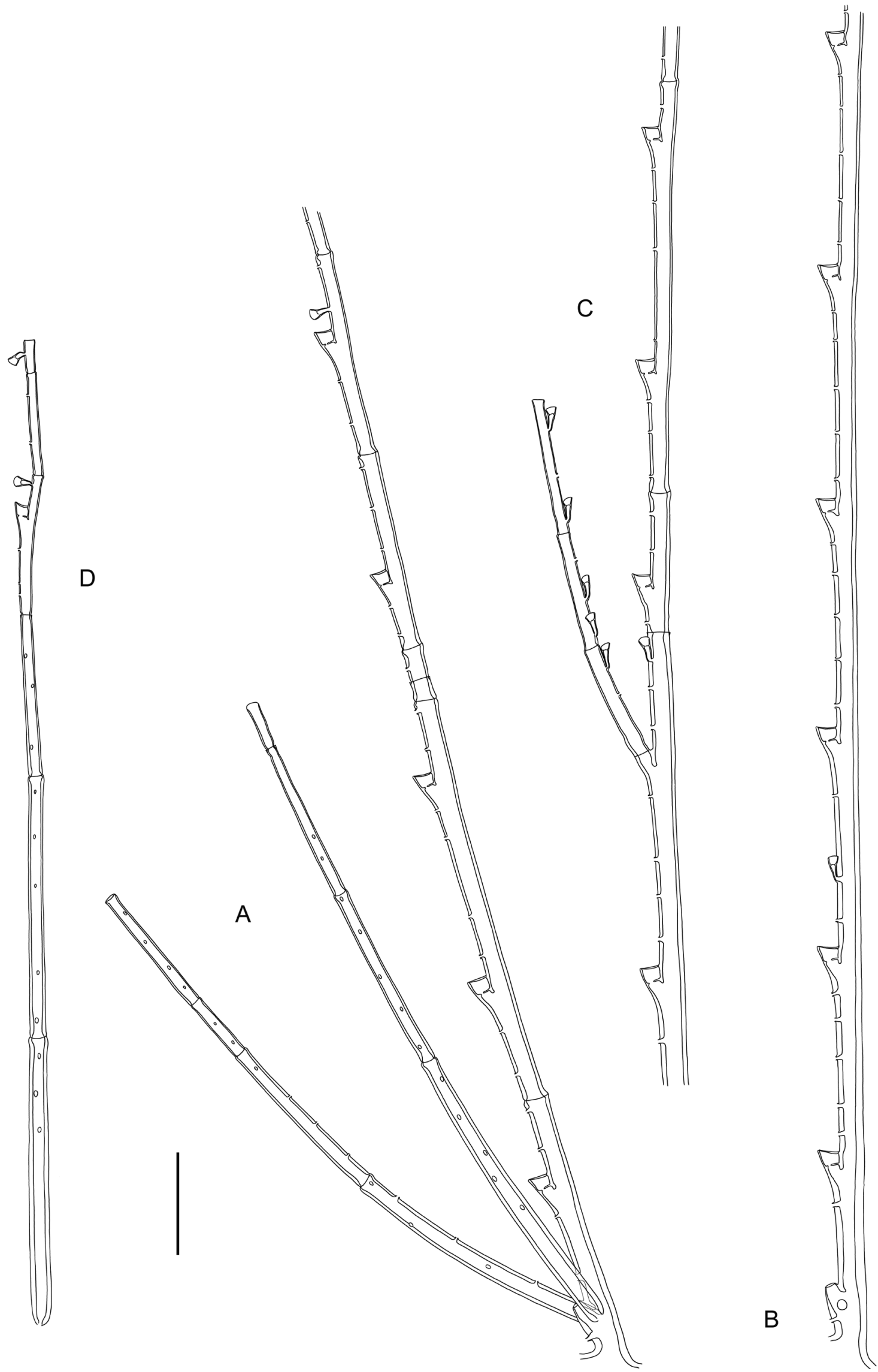
Table 1. Measurements of Actinopluma mirifica Galea gen. et sp. nov., in $\mu \mathrm{m}$.

\begin{tabular}{lc}
\hline & MNHN-IK-2015-612 \\
\hline Caulus & \\
- distance between 2 successive cladial apophyses & $400-470$ \\
- diameter & $95-100$ \\
Main cladia & \\
- distance between 2 successive hydrothecae & $600-755$ \\
- diameter & $45-65$ \\
Accessory cladia & \\
- diameter & $35-40$ \\
Hydrotheca & \\
- abaxial wall, length & $40-50$ \\
- adaxial wall, length & $30-35$ \\
- base, width & $35-40$ \\
- diameter at rim & $45-50$ \\
Nematothecae & \\
- length & $70-75$ \\
- diameter at rim & $25-30$ \\
- mamelon, diameter at aperture & ca 20 \\
\hline
\end{tabular}

\section{Remarks}

As noted above, the segmentation of the cladia is very irregular. When only one hydrotheca is to be found on an internode, there is a number of nematothecae below and above it, respectively: $2-1,2-3,3-1$, $3-2,4-1,4-2,6-1$. When two hydrothecae are confined to an internode, the number of nematothecae below the proximal hydrotheca, between the two hydrothecae, and above the second hydrotheca, could be as follows: $2-5-2,3-4-1,3-5-1,3-5-2,4-4-1,4-5-1$. In the case of internodes bearing three hydrothecae, the number of nematothecae below the first hydrotheca, between the first and second, the second and third hydrotheca, and above the third hydrotheca, could be: 3-5-5-1 and 3-5-5-2. When four hydrothecae are confined to an internode, the number of nematothecae below the first hydrotheca, between the first and second, second and third, third and fourth, and above the fourth hydrotheca, is generally $3-5-5-5-1$.

In the colony from MNHN-IK-2015-613, an additional accessory hydrocladium is given off from one side of the first cladial hydrotheca.

\section{Distribution}

Only known from its type locality, Coral Sea off New Caledonia (present study).

Family Plumulariidae McCrady, 1859

Genus Dentitheca Stechow, 1919

Dentitheca contraria (Ansín Agís et al., 2014) comb. nov.

Fig. 6A-B

Plumularia contraria Ansín Agís et al., 2014: 800, figs 6-7.

\section{Material examined}

PACIFIC OCEAN - $1 \mathrm{ca} 21 \mathrm{~cm}$ high, sterile colony, devoid of its hydrorhiza; off New Caledonia, stn DW4742; 225' S, 167³7' E; 290-345 m; 23 Aug. 2016; KANACONO leg.; barcode identifier MT655149; MNHN-IK-2015-582 - 1 ca 14 cm high, sterile colony without hydrorhiza; off New

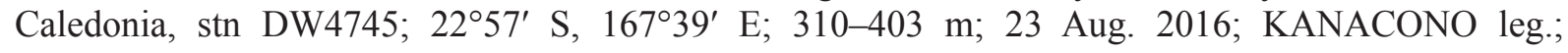


MNHN-IK-2015-583 - 1 ca $20 \mathrm{~cm}$ high, sterile colony; off New Caledonia, stn DW4741; 22 ${ }^{\circ} 52^{\prime}$ S, 167 $41^{\prime}$ E; 210-210 m; 23 Aug. 2016; KANACONO leg.; barcode identifier MT655150; MNHN-IK-2015-584 - a fully fertile colony of ca $19 \mathrm{~cm}$ in height; off New Caledonia, stn DW4744; 22 $2^{\circ} 5^{\prime}$ S, 167 $37^{\prime}$ E; 310-290 m; 23 Aug. 2016; KANACONO leg.; barcode identifier MT655151; MNHN-IK-2015-585 - a $8.5 \mathrm{~cm}$ high, sterile colony; off New Caledonia, stn DW4743; $22^{\circ} 52^{\prime} \mathrm{S}$, 167³4' E; 380-340 m; 23 Aug. 2016; KANACONO leg.; MNHN-IK-2015-592.

\section{Additional material}

BALI SEA -3 sterile colonies of D. elongata, $8-11 \mathrm{~cm}$ high; Indonesia, NE Bali, near Amed, Japanese shipwreck; 8²1'50.29" S, 11542'1.61" E; 5-15 m; 4 Oct. 2010; HRG-1236.

CELEBES SEA • $1 \mathrm{ca} 9 \mathrm{~cm}$ high, fully-fertile colony fragment of Dentitheca elongata (Billard, 1913); Indonesia, Derawan Archipelago, off Sangalaki Island; 205'21" N, 118 24'04" E; 20 m; 23 Apr. 2010; HRG-0132.

\section{Remarks}

For a comprehensive account on the trophosome of this species, refer to Ansín Agís et al. (2014).

Gonothecae were not documented in the original account, but the material MNHN-IK-2015-585 is a fertile colony. Its gonothecae are borne on the side branches in the axil formed by the cladial apophyses with their corresponding internodes; they are broadly piriform, with a truncate distal end that bears a wide, circular aperture closed by a filmy perisarc, possibly becoming a deciduous operculum that is lost upon the release of the gonophores. The latter are undoubtedly medusoids, as suggested by the presence of an apical belt of small, spherical, refringent corpuscles. Two or three large oocytes, occupying the whole subumbrellar cavity, are clearly discernible inside each gonophore (Fig. 6B).

The elongated hydrothecae, whose lateral walls produce two arched lobes flanking their apertures, the characteristic shape of the gonotheca, and the production of medusoid gonophores, suggest that this species is better assignable to the genus Dentitheca Stechow, 1919.

For the same reasons as those listed above, additionally supported by molecular evidence (Moura et al. 2018), Plumularia elongata Billard, 1913 is equally assigned to Dentitheca, as D. elongata comb. nov. As noted by Ansín Agís et al. (2014), this species shows certain similarities with D. contraria comb. nov., notably the shape of its hydrothecae. However, Billard's species forms planar colonies, while those of $D$. contraria comb. nov. have spirally-arranged cladia-bearing branches; additionally, the cladial internodes of the latter continue for a longer distance above the hydrotheca, and are provided there with an additional nematotheca, otherwise absent in D. elongata (compare Fig. 6A and Fig. 6C).

Piriform gonothecae, very similar to those of $D$. contraria comb. nov., some of them reportedly containing a medusoid gonophore, are known for instance in D. alata (Bale, 1888) (Watson 1997: fig. 7e; probable medusoid), D. asymmetrica (Bale, 1914) (Bale 1914: 30; medusoid), D. bidentata (Jäderholm, 1920) (Migotto \& Marques 1999: figs 1e, 3b-d, 4; medusoid), D. dendritica (Nutting, 1900) (Galea et al. 2012: figs 1c-m, 2a-g; medusoid), D. elongata (Billard, 1913) (Di Camillo et al. 2010: figs 2e, 3d, as D. habereri), D. habereri (Stechow, 1909) (Inaba 1892: fig. 9, as Plumularia sp.; Stechow 1913: fig. 60; probably medusoid), and $D$. hertwigi (Stechow, 1907) (Stechow 1913: fig. T ${ }^{1}$; Hirohito 1995: fig. 88d-e; probably medusoid).

\section{Distribution}

Scattered records form off New Caledonia (Ansín Agís et al. 2014; present study). 
Dentitheca habereri (Stechow, 1909)

Fig. 6D

Plumularia habereri Stechow, 1909: 77, pl. 6 fig. 4.

Plumularia habereri var. attenuata Billard, 1913: 42, fig. 34.

Plumularia habereri var. mucronata Billard, 1913: 46, fig. 40, pl. 2 fig. 24.

Dentitheca habereri - Stechow 1920: 33; 1923a: 18; 1923b: 227. — Yamada 1959: 80. — Hirohito

1969: 25; 1974: 66; 1995: 259, fig 87a-c. — Kirkendale \& Calder 2003: 167.

Dentitheca dendritica - Nutting 1927: 224 [non Dentitheca dendritica (Nutting, 1900)].

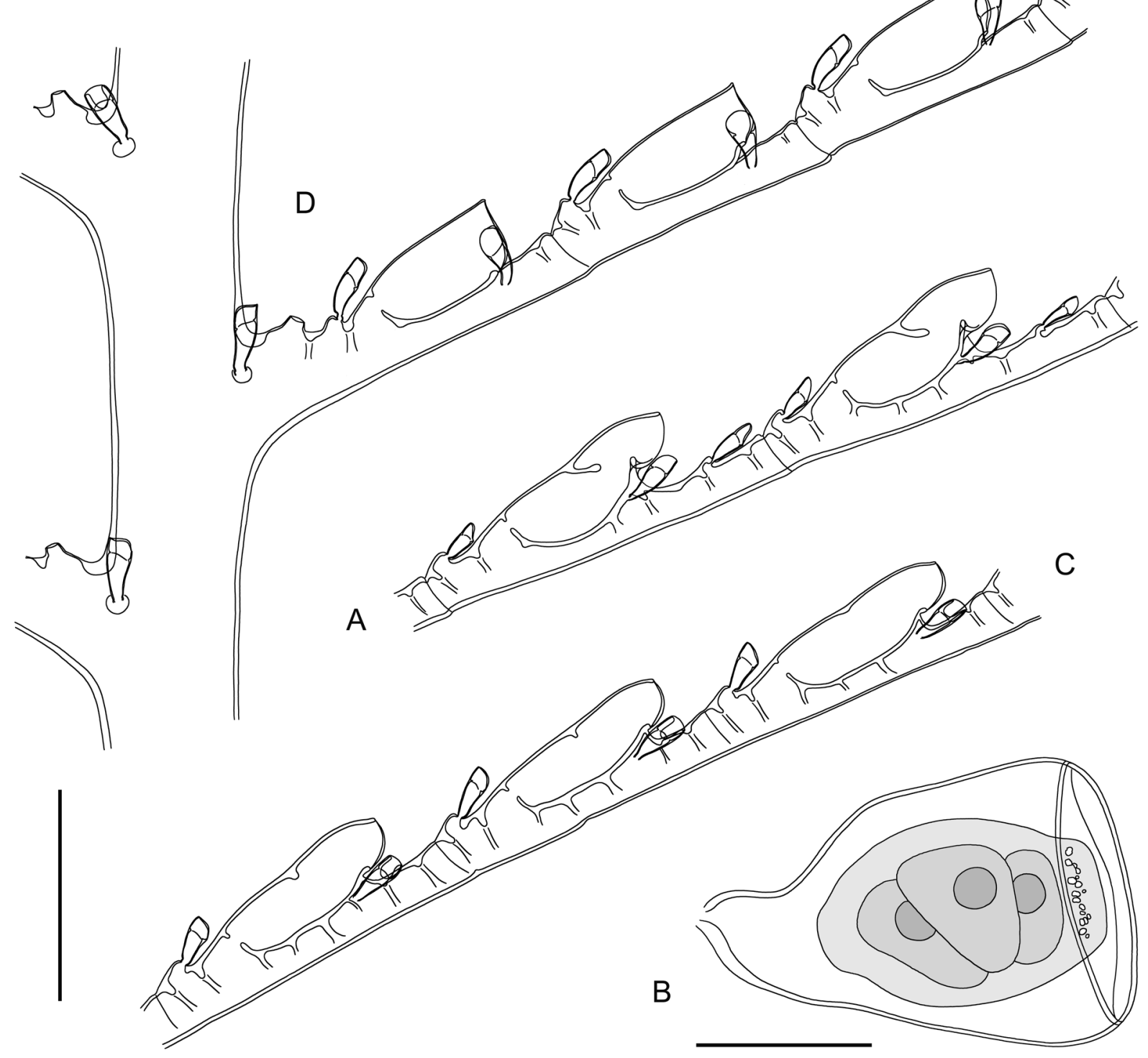

Fig. 6. A-B. Dentitheca contraria (Ansín Agís et al., 2014), portion of cladium (A) from sample MNHNIK-2015-582, and comparison with its counterpart of Dentitheca elongata (Billard, 1913), sample HRG1236 (C); gonotheca with female medusoid (B), from sample MNHN-IK-2015-585. — D. Dentitheca habereri (Stechow, 1909), portion of monosiphonic stem with three cladial apophyses and proximalmost part of a cladium, from sample MNHN-IK-2015-573. Scale bars: A, C-D = $300 \mu \mathrm{m} ; \mathrm{B}=200 \mu \mathrm{m}$. 
Plumularia habereri - Bedot 1921a: 27. — Stechow 1913: 91, figs 59-60. — Ryland \& Gibbons 1991: 532, fig. 5. - Ruthensteiner et al. 2008: 20. — Ansín Agís et al. 2014: 806, figs 9-13. — Tseng et al. 2014: 3-5. - Schuchert 2015: 349, fig. 22.

Plumularia habereri var. attenuata - Bedot 1921a: 27.

Plumularia habereri attenuata - Van Praët 1979: 923.

Plumularia habereri var. mucronata - Bedot 1921a: 27.

Plumularia sp. - Inaba 1892: 350, figs 8-10.

non Plumularia habereri - van Gemerden-Hoogeveen 1965: 60, figs 34-36 [= Dentitheca dendritica (Nutting, 1900)]. - Schuchert 2003: 211, fig. 60 [= Dentitheca elongata (Billard, 1913)].

non Dentitheca habereri - Di Camillo et al. 2010: 4, figs 2-3 [= Dentitheca elongata (Billard, 1913)]. non Plumularia habereri var. elongata Billard, 1913: 44, figs 25-27 [= Dentitheca elongata (Billard, 1913)].

non Plumularia habereri var. mediolineata Billard, 1913: 45, fig. 39 [= Dentitheca elongata (Billard, 1913)].

non Plumularia habereri var. subarmata Billard, 1913: 45, fig. 38 [= Dentitheca elongata (Billard, 1913)].

\section{Material examined}

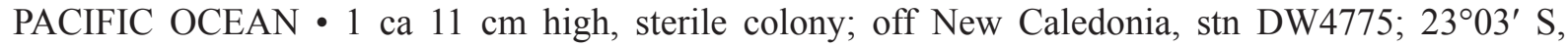
168 $17^{\prime}$ E; 140-277 m; 28 Aug. 2016; KANACONO leg.; barcode identifier MT655145; MNHN-IK-2015-573 1 ca $10.5 \mathrm{~cm}$ high, sterile colony; off New Caledonia, stn DW4743; 2252' S, 167³4' E; 380-340 m; 23 Aug. 2016; KANACONO leg.; MNHN-IK-2015-574 • 1 ca 16 cm high, sterile colony; off New Caledonia, stn DW4741; 22 ${ }^{\circ} 52^{\prime}$ S, 16741' E; 210-210 m; 23 Aug. 2016; KANACONO leg.; MNHN-IK-2015-575 3 sterile colonies, 16, 18 and $35 \mathrm{~cm}$ high; off New Caledonia, stn DW4727; $22^{\circ} 41^{\prime} \mathrm{S}, 167^{\circ} 02^{\prime} \mathrm{E}$; 120-129 m; 20 Aug. 2016; KANACONO leg.; MNHN-IK-2015-577 • a $5.5 \mathrm{~cm}$

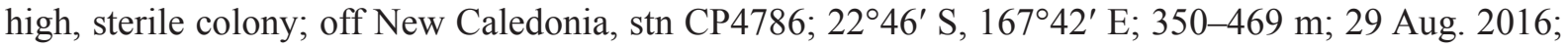
KANACONO leg.; MNHN-IK-2015-591.

\section{Remarks}

A recent, comprehensive account is given by Ansín Agís et al. (2014). Despite their opinion, this species is here reassigned to Dentitheca on the account of the emarginated hydrothecal rim on the adaxial side, creating two latero-posterior, triangular lobes, and the morphology of its gonothecae, as noted above under D. contraria comb. nov.

The Philippines record by Nutting (1927, as Plumularia dendritica), very likely belongs to the present species. Despite Nutting' statement that his material agrees "very exactly with the original descriptions and figures, and a comparison with the type specimens in the museum of the State University of Iowa confirms this view", it is believed that this author was mistaken by some obvious similarities between the hydrothecae of these two species. Indeed, upon a close examination, it appears that the hydrothecal rim of $D$. dendritica has a pair of distinct, lateral cusps before the adaxial emargination, while the adaxial wall of $D$. habereri produces comparatively less marked cusps (compare Galea (2010: fig. 7d-e) with Fig. 6D herein). It is very unlikely that a common species of the tropical western Atlantic occurs in the tropical western Pacific as well, and no subsequent records of $D$. dendritica have been reported from this area.

\section{Distribution}

Indonesia (Billard 1913), Japan (Hirohito 1995), Taiwan (Tseng et al. 2014), Philippines (Nutting 1927, as Plumularia dendritica; Ansín Agís et al. 2014, as P. habereri), Coral sea off New Caledonia (Ansín Agís et al. 2014; present study); Fiji (Ryland \& Gibbons 1991), Guam (Kirkendale \& Calder 2003). 
Genus Plumularia Lamarck, 1816

Plumularia conjuncta Billard, 1913

Figs 7, 8A-F; Table 2

Plumularia insignis var. conjuncta Billard, 1913: 49, figs 42-43 (non Plumularia insignis Allman, 1883: 21, pl. 2 figs 1-4).

Plumularia insignis var. conjuncta - Bedot 1921a: 28.

Plumularia insignis conjuncta - Van Praët 1979: 925.

Plumularia conjuncta - Ansín Agís et al. 2016: 83, fig. 15.

\section{Material examined}

PACIFIC OCEAN $11 \mathrm{ca} 30 \mathrm{~cm}$ high, sterile colony devoid of hydrorhiza; off New Caledonia, stn CP5019; $21^{\circ} 09^{\prime} \mathrm{S}, 159^{\circ} 11^{\prime}$ E; 400-640 m; 20 Sep. 2017; KANADEEP leg.; MNHN-IK-2015-590.

\section{Description}

Colony ca $30 \mathrm{~cm}$ high, detached from its substrate immediately above origin from hydrorhiza; flaccid, delicate, composed of lightly fascicled, slender, exceedingly elongate stem, composed of a few auxiliary tubes surrounding main tube that gives rise regularly to spirally-arranged, monosiphonic, up to $2 \mathrm{~cm}$ long hydrocladia-bearing branches, $0.35-0.55 \mathrm{~mm}$ distant from one another; main stem neither divided into internodes nor with internal partitions of perisarc, with row of frontal nematothecae, and short, inconspicuous apophyses supporting lateral branches. The latter arch graciously outwards and nearly horizontally; division into internodes inconspicuous, though incomplete transverse septa delimit segments composed of 1-2 apophyses for hydrocladia; nematotheca a certain distance above each apophysis on opposite side of internode; each internode with dense, annular, internal perisarcal ridges; apophyses alternate, shifted on to lower side of branches, resulting in cladia facing downwards and forming acute angle between two rows; mamelon and pair of nematothecae on each side of axil. Cladia sinusoid, up to $2.5 \mathrm{~mm}$ long, heteromerously divided into internodes by means of transverse nodes; proximally, 1-2 short internodes, first one athecate, second always bearing nematotheca; remainder of cladium composed of sequence of up to 3 hydrothecate internodes alternating with short, ahydrothecate internodes provided with proximally-placed nematotheca on their upper side; all internodes with two incomplete internal ridges near both ends; hydrothecate internode about thrice length of their ahydrothecate counterparts, with centrally-placed, deep, tubular, wholly adnate hydrotheca and its three associated nematothecae: one mesial, far below hydrothecal base, borne on small protuberance, and pair of laterals, not situated at same level, borne on indistinct apophyses; hydrothecal rim entire, circular in apical view, slightly scooped when seen in lateral view, aperture tilted abaxially; all nematothecae bithalamic, conical, with high basal chamber and relatively shallow upper chamber, whose rim is slightly lowered on adaxial side. Gonothecae unknown.

\section{Remarks}

Considered as a variety of Plumularia insignis Allman, 1883 by Billard (1913), it was raised to species by Ansín Agís et al. (2016) upon the reexamination of Allman's hydroid. Plumularia conjucta was exclusively known earlier from its holo- (a $5 \mathrm{~mm}$ long fragment) and schizoholotype (a $1.5 \mathrm{~mm}$ long fragment).

\section{Distribution}

Sulu Sea (Billard 1913), Coral Sea off New Caledonia (present study). 


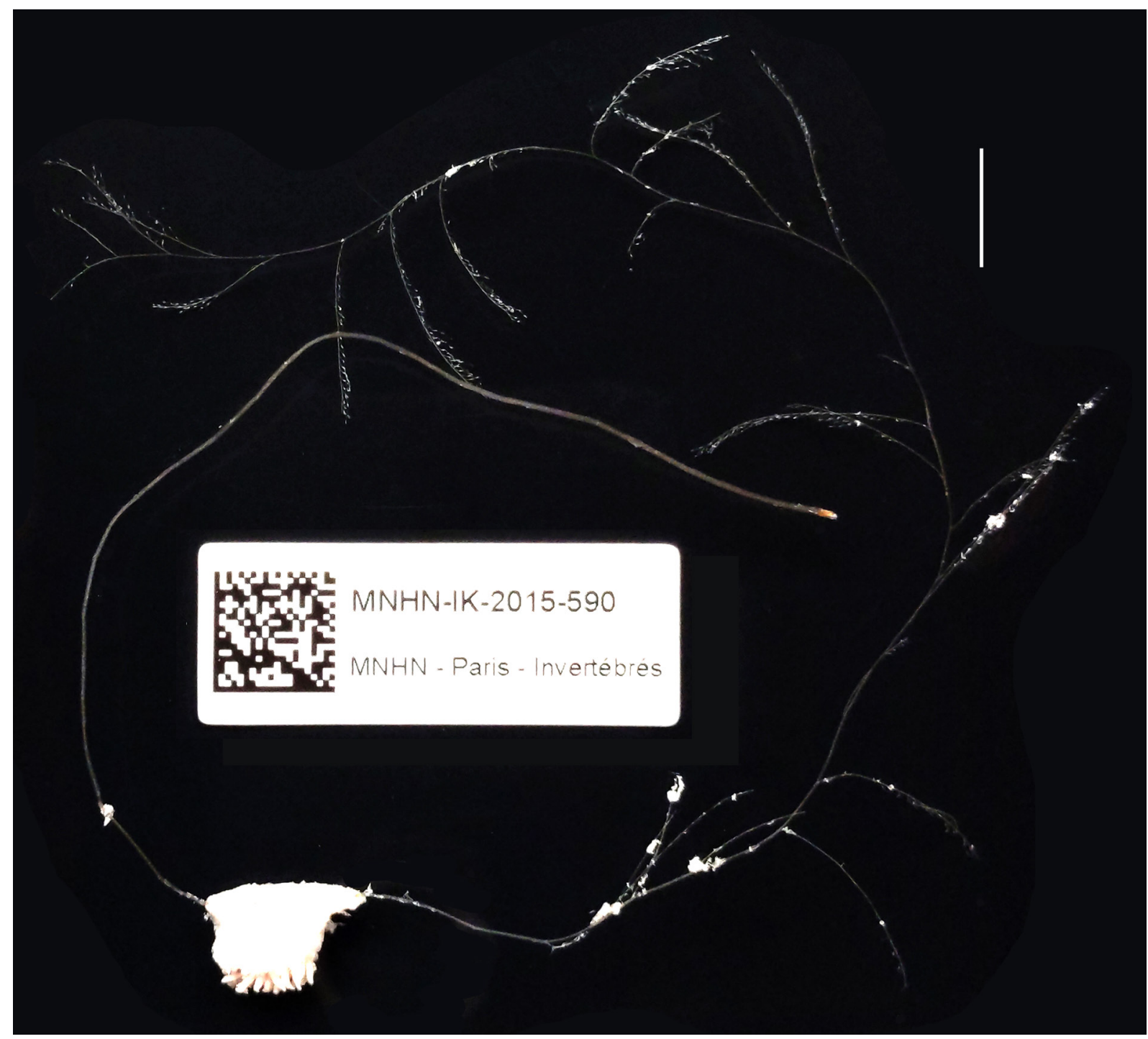

Fig. 7. Plumularia conjuncta Billard, 1919, colony, MNHN-IK-2015-590. Scale bar: $2 \mathrm{~cm}$.

Plumularia setacea Linnaeus, 1758

Fig. 8G

Plumularia setacea - Schuchert 2013: 117, figs 2a-b, 4-6. — Ansín Agís et al. 2014: 824, fig. 22.

\section{Material examined}

PACIFIC OCEAN $• 2$ cormoids, ca $3.5 \mathrm{~cm}$ high, one of them with 9 gonothecae; off New Caledonia, stn DW4670; 225ㅇ' S, 167²4' E; 680-612 m; 12 Aug. 2016; KANACONO leg.; MNHN-IK-2015-594.

\section{Distribution}

Nearly cosmopolitan (Schuchert 2013), except for Arctic and Antarctic waters. According to Schuchert (2014), the taxon could be regarded as either a multitude of cryptic, geographically delimited lineages, or as a species with an extensive population subdivision. 


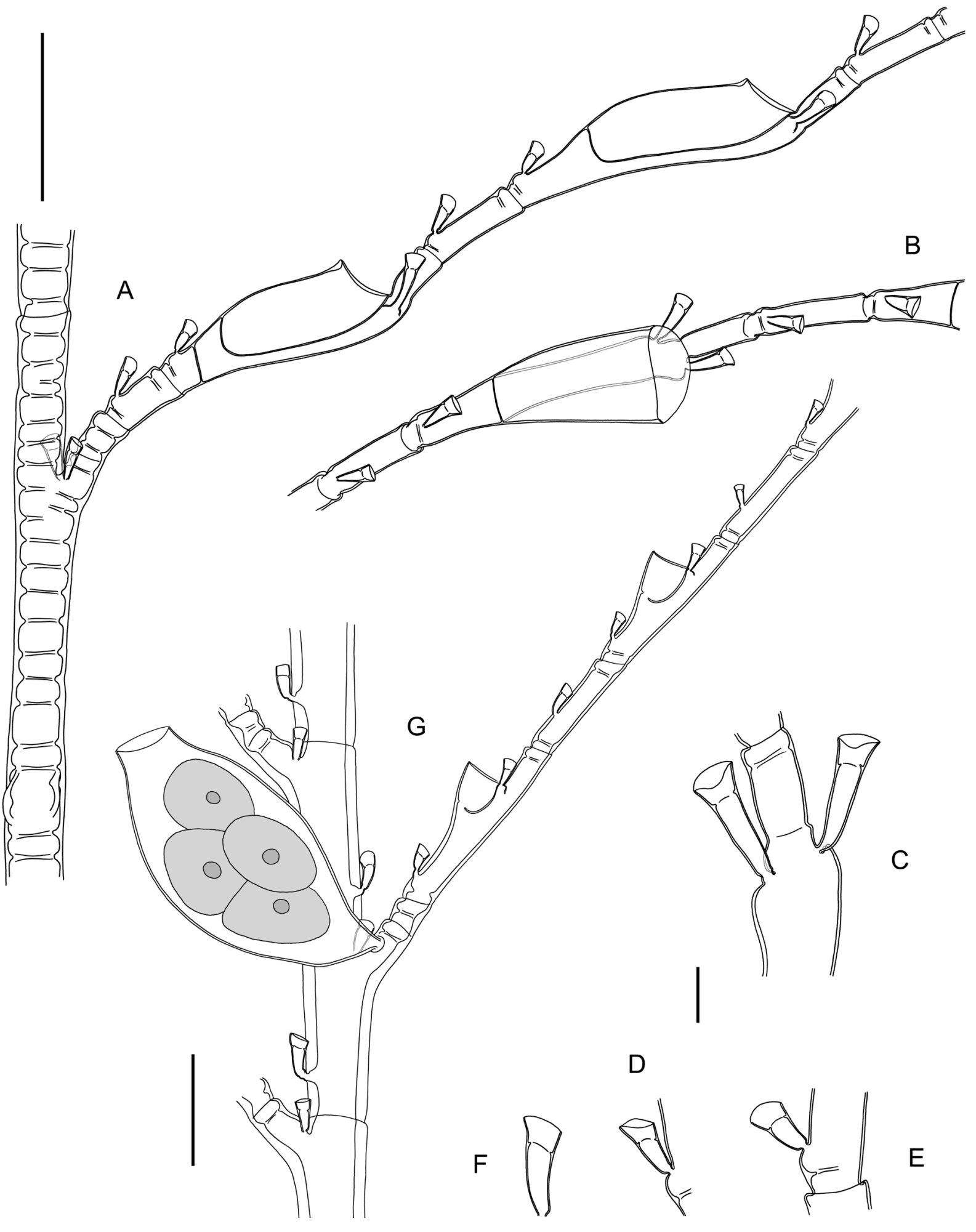

Fig. 8. A-F. Plumularia conjuncta Billard, 1919, portion of branch with proximalmost part of a cladium seen laterally (A); portion of cladium in frontal view (B); insertion of lateral nematothecae, seen frontally (C); nematothecae: mesial (D), from cladial intersegment (E) and from axil of cladium (F); all from sample MNHN-IK-2015-590. - G. Plumularia setacea (Linnaeus, 1758), portion of stem, proximal part of a cladium and female gonotheca, from sample MNHN-IK-2015-594. Scale bars: A-B, G = 300 $\mu \mathrm{m} ; \mathrm{C}-\mathrm{F}=50 \mu \mathrm{m}$. 
Table 2. Measurements of Plumularia conjuncta Billard, 1913, in $\mu \mathrm{m}$.

\begin{tabular}{lccc}
\hline & Present study & Billard (1913) & Ansín Agís et al. (2016) \\
\hline Branches & & & - \\
- distance between cladia & $550-635$ & - & - \\
- diameter at node & $85-115$ & - & - \\
Cladia & & & - \\
- $1^{\text {st }}$ (athecate) internode (if present), length & $85-95$ & - & $150-160$ \\
- - $^{\text {or }}$ 2 $^{\text {nd }}$ (nematothecate) internode, length & $100-135$ & $135-175$ & $146-160$ \\
- ahydrothecate internodes, length & $140-215$ & - & - \\
- nematothecae, length & $65-75$ & - & - \\
- nematothecae, diameter at rim & $30-35$ & $510-610$ & $530-600$ \\
- hydrothecate internodes, length & $550-685$ & $55-70$ & $50-70$ \\
- diameter at node & $40-60$ & & \\
Hydrotheca & $225-280$ & $215-270$ & $210-250$ \\
- abaxial wall, length & $315-330$ & - & $240-280$ \\
- adaxial wall, length & $115-130$ & $95-110$ & $105-110$ \\
- diameter at rim & $70-75$ & - & $70-80$ \\
- mesial nematotheca, length & $30-35$ & - & $30-40$ \\
- mesial nematotheca, diameter at rim & $100-105$ & - & $85-90$ \\
- lateral nematotheca, length & $35-40$ & - & $30-40$ \\
- lateral nematotheca, diameter at rim & & &
\end{tabular}

Genus Schizoplumularia Ansín Agís et al., 2016

Schizoplumularia elegans Ansín Agís et al., 2016

Figs 9A, 10A

Schizoplumularia elegans Ansín Agís et al., 2016: 67, figs 6-9.

\section{Material examined}

PACIFIC OCEAN -6 sterile colonies, 10-18 cm high; off New Caledonia, stn DW4703; 22 ${ }^{\circ} 46^{\prime} \mathrm{S}$, $167^{\circ} 19^{\prime}$ E; 350-348 m; 17 Aug. 2016; KANACONO leg.; barcode identifier MT655139; MNHNIK-2015-548 1 ca 9 cm high, sterile colony; off New Caledonia, stn DW4714; 22 $49^{\prime} \mathrm{S}, 1^{\circ} 7^{\circ} 25^{\prime} \mathrm{E}$; 394-443 m; 18 Aug. 2016; KANACONO leg.; MNHN-IK-2015-566 • 1 ca 13 cm high, sterile colony; off New Caledonia, stn CP4657; 22042' S, 167¹4' E, 270-282 m; 10 Aug. 2016; KANACONO leg.; barcode identifier MT655143; MNHN-IK-2015-567 • 2 sterile colonies, 5.5 and $10 \mathrm{~cm}$ high, respectively; off New Caledonia, stn DW4949; 240ㄱ' S, 159 41' E; 280-300 m; 5 Sep. 2017; KANADEEP leg.; MNHN-IK-2015-568 - 1 sterile colony, ca $6 \mathrm{~cm}$ high upper part; off New Caledonia, stn CP4704; $22^{\circ} 46^{\prime}$ S, $167^{\circ} 19^{\prime}$ E; 365-356 m; 17 Aug. 2016; KANACONO leg.; MNHN-IK-2015-581.

\section{Remarks}

For a description of this species, refer to Ansín Agís et al. (2016).

\section{Distribution}

Scattered records from off New Caledonia (Ansín Agís et al. 2016; present study).

Schizoplumularia helicoidalis sp. nov. urn:1sid:zoobank.org:act:902D24C0-DC53-4610-A3D0-80EBC01A9B09

Figs 9B, 10B-K; Table 3

Schizoplumularia elegans Ansín Agís et al., 2016 (pro parte): 68, 72, figs 6a, 8 [non S. elegans Ansín Agís et al. 2016 (pro parte): 67, figs 6b-e, 7, (?) 9]. 


\section{Diagnosis}

Schizoplumularia with slender, flaccid, geniculate stem, lightly fascicled proximally, then composed of only two adjacent tubes for most of its length; tubes with scattered nematothecae along their length; at each geniculation, one tube, while diverging as a cladia-bearing branch, gives rise to an auxiliary
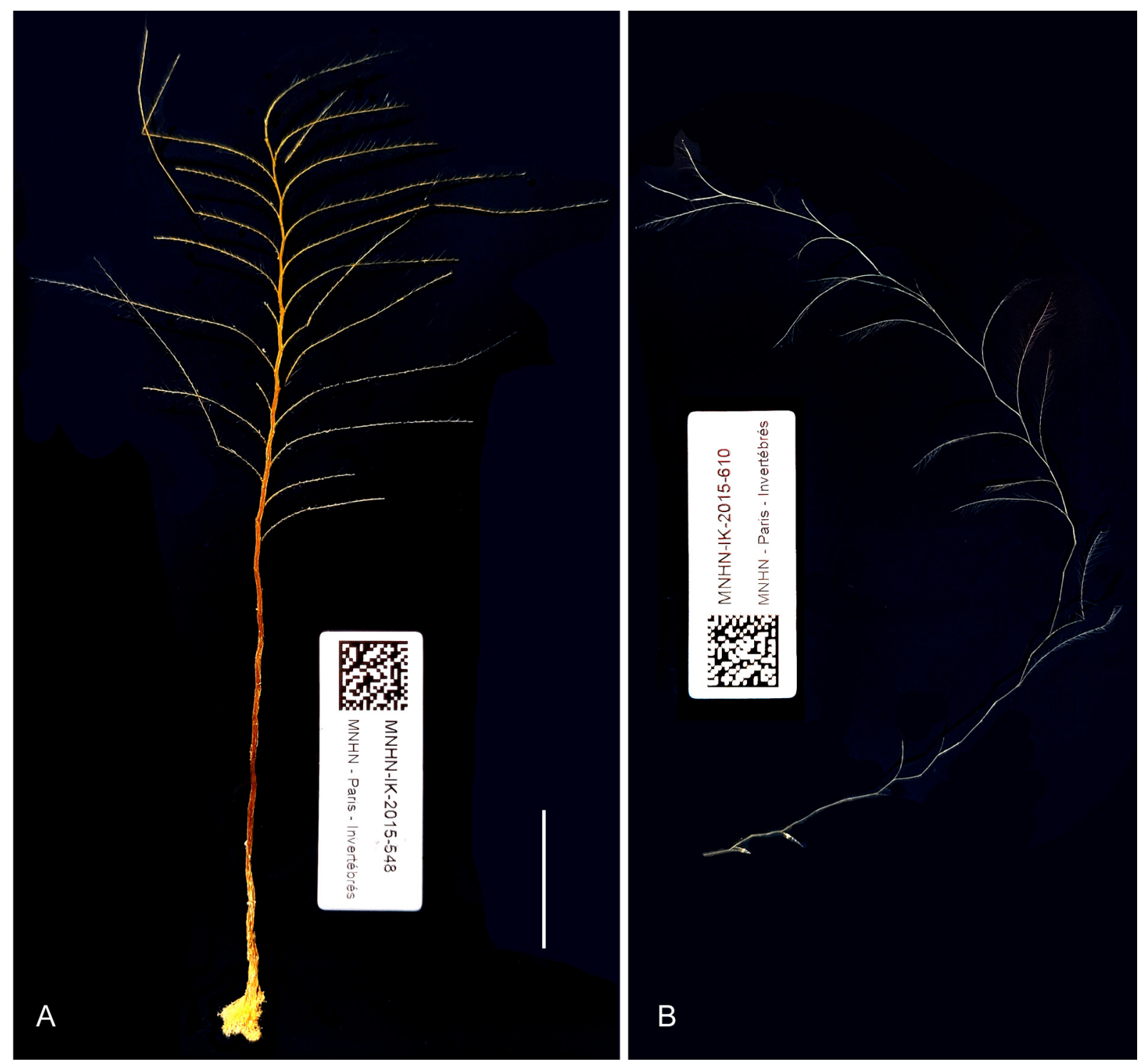

Fig. 9. A. Schizoplumularia elegans Ansín Agís et al., 2016, colony from sample MNHN-IK-2015-548. - B. Schizoplumularia helicoidalis sp. nov., holotype colony, MNHN-IK-2015-610. Scale bar: $2 \mathrm{~cm}$.

Fig. 10 (opposite page). A. Schizoplumularia elegans Ansín Agís et al., 2016, monosiphonic portion of a branch with proximal part of a cladium, from sample MNHN-IK-2015-548. - B-K. Schizoplumularia helicoidalis sp. nov., portion of stem showing fate of component tubes (B); portion of branch with five successive cladial apophyses and proximal part of a cladium $(\mathrm{C})$; portions of cladia from material other than the holotype (D-E); detail of cladial apophysis (F); cladial internode with hydrotheca and its associated nematothecae $(\mathrm{G})$; nematothecae of stem $(\mathrm{H})$ and of cladial intersegment in adaxial (I) and lateral (J) views; gonotheca from material not belonging to the type (K); B-C, F-J from the holotype, MNHN-IK-2015-610; D-E, K from sample MNHN-IK-2015-596. Scale bars: A, C-E = $300 \mu \mathrm{m}$; B = $1 \mathrm{~mm} ; \mathrm{F}-\mathrm{K}=100 \mu \mathrm{m}$. 


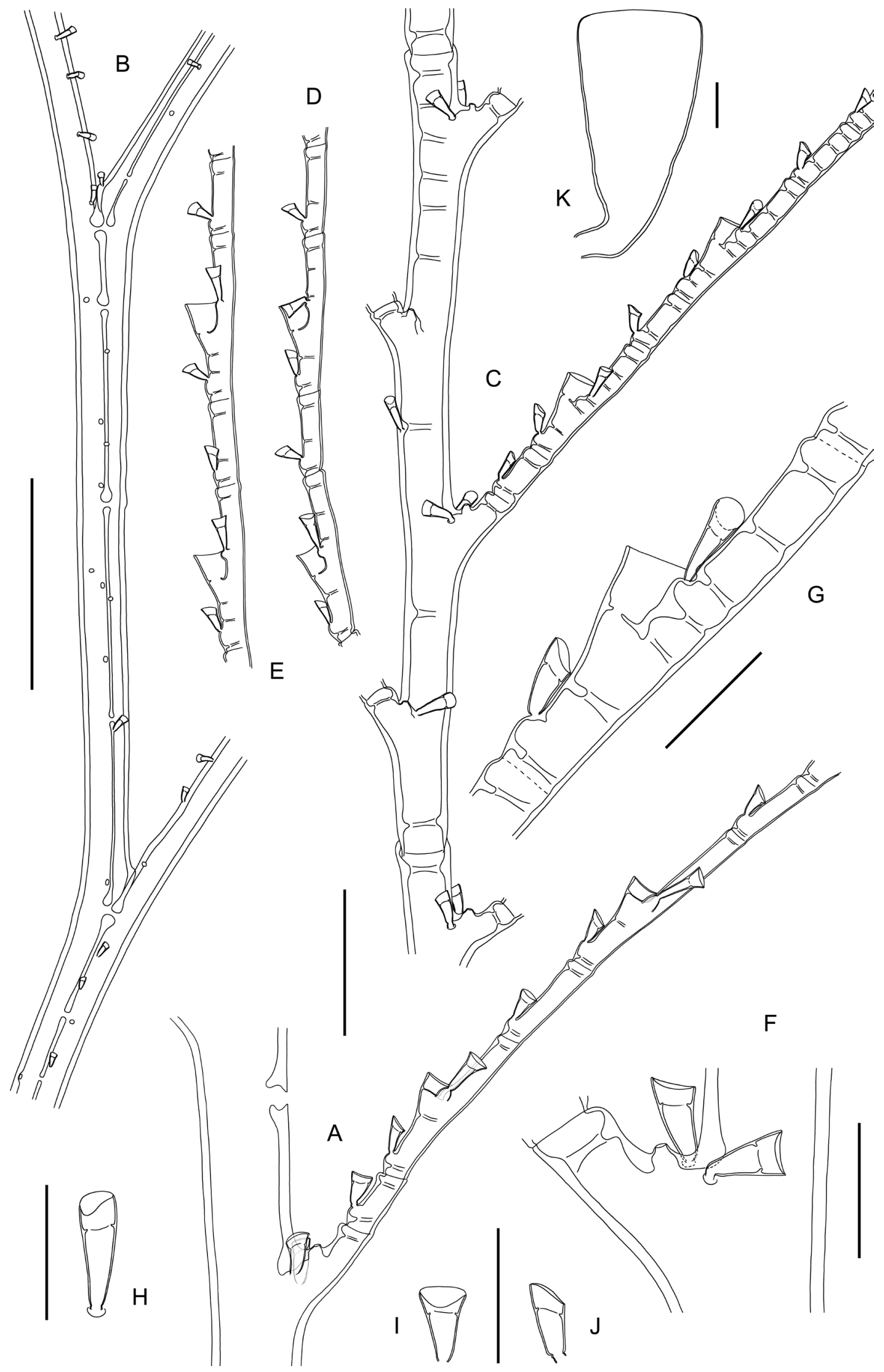


tube running upwards along the second tube, a situation that is reversed throughout the stem; branches undivided, but each equivalent of internode with a latero-distal cladial apophysis (the latter with a mamelon and 2 axillar nematothecae) and 1-2 nematothecae on side opposite the apophysis; apophyses shifted on to the upper side of the branch; cladia heteromerously segmented into short, ahydrothecate internodes with 1 nematotheca alternating with comparatively longer hydrothecate internodes bearing a small, cup-shaped hydrotheca and its 3 associated nematothecae.

\section{Etymology}

From Greek ' $\dot{\varepsilon} \lambda l \kappa o \varepsilon l \delta \eta^{\prime} \varsigma$ ', meaning 'in the form of a helix', to describe the arrangement of the cladiabearing branches along the stem.

\section{Material examined}

\section{Holotype}

PACIFIC OCEAN • a $15.5 \mathrm{~cm}$ high, sterile colony without hydrorhiza; off New Caledonia, stn DW4711; 224ㄱ' S, 167²4' E; 335-338 m; 18 Aug. 2016; KANACONO leg.; MNHN-IK-2015-610.

\section{Additional material}

PACIFIC OCEAN $-1 \mathrm{ca} 6 \mathrm{~cm}$ high, sterile colony, and the top part (ca $2 \mathrm{~cm}$ high) of a colony with immature gonothecae; off New Caledonia, stn DW4762; $23^{\circ} 16^{\prime} \mathrm{S}, 168^{\circ} 06^{\prime} \mathrm{E}$; 810-805 m; 26 Aug. 2016; KANACONO leg.; barcode identifier MT655152; MNHN-IK-2015-596.

\section{Description}

A $15.5 \mathrm{~cm}$ high colony of very delicate and flaccid appearance, detached from its hydrorhiza; stem slender, composed proximally of bundle of few tubes running parallel to each other and communicating, at intervals, through common holes in the perisarc; nematothecae scattered along their length; more distally, remainder of stem composed of only two contiguous tubes forming alternately-placed geniculations at intervals of $3.5-5.5 \mathrm{~mm}$; at each geniculation, one of tubes diverges from stem at acute angle and transforms itself into cladia-bearing branch; it also gives rise simultaneously, at level of axil thus formed with its henceforth single counterpart, to another tube running upward along that counterpart, so as to ensure the obligatory presence of two adjacent tubes composing stem; at next geniculation, there is a reversal of roles played by couple of tubes: that newly-added at previous geniculation continues unaffected (skips one geniculation), while its counterpart detaches distally from stem as cladia-bearing branch; stem tubes with two parallel rows of alternately-placed nematothecae; between successive geniculations, stem acquires slight torsion, so that its cladia-bearing branches are arranged in helicoidal manner along it. Stem, branches and cladia very slender; perisarc straw colored. Cladia-bearing branches up to $2 \mathrm{~cm}$ long, unsegmented, but each equivalent of internode with distallyplaced cladial apophysis and 1-2 nematothecae on side opposite to apophysis (up to 6 nematothecae in two closely-set whorls found on proximalmost 'internode'); apophyses alternate, not coplanar, but forming wide angle between two rows; axil with conical mamelon provided with rounded aperture on summit, and two nematothecae, one on each side. Cladia up to $2.5 \mathrm{~mm}$ long, heteromerously segmented by means of transverse nodes into alternating ahydrothecate and hydrothecate internodes; proximalmost internode ahydrothecate, slightly shorter than its subsequent counterparts, with proximal nematotheca on its upper side; ahydrothecate internodes with generally two (occasionally up to four) internal, incomplete perisarc ridges near both ends, and proximal nematotheca placed frontally; hydrothecate internodes, up to 6 per cladium, comparatively longer than their ahydrothecate counterparts, with almost centrally-placed hydrotheca and its three associated nematothecae: a mesial one and pair of laterals; up to eight internal incomplete perisarcal ridges per hydrothecate internode. Nematothecae of colony all alike: trumpet-shaped, bithalamic, lower chamber tall, upper chamber shallow, wall of the latter lowered on adaxial side. Gonothecae in axils of cladia-bearing branches; immature in material at hand; broadly 
Table 3. Measurements of Schizoplumularia helicoidalis sp. nov., in $\mu \mathrm{m}$.

\begin{tabular}{lcc}
\hline & $\begin{array}{c}\text { Present study, } \\
\text { MNHN-IK-2015-610 }\end{array}$ & $\begin{array}{c}\text { Ansín Agís et al. (2016), } \\
\text { SMIB 4, stn DW53, as } \\
\text { S. elegans (pro parte) }\end{array}$ \\
\hline Branches & $510-660$ & - \\
- distance between successive cladia & $120-130$ & - \\
- diameter & $80-90$ & - \\
- cladial apophyses, length & & \\
Cladia & $115-140$ & $130-170$ \\
- 1t internode, length & $165-180$ & $150-190$ \\
- ahydrothecate internodes, length & $60-65$ & - \\
- nematotheca, length & ca 30 & - \\
- nematotheca, diameter at rim & $335-365$ & $330-360$ \\
- hydrothecate internodes, length & $45-50$ & $35-50$ \\
- diameter at node & & \\
Hydrotheca & $45-55$ & $50-60$ \\
- abaxial wall, length & $55-60$ & $50-65$ \\
- adaxial wall, length & $55-60$ & $60-65$ \\
- diameter at rim & $60-65$ & $50-60$ \\
- mesial nematotheca, length & ca 30 & $30-35$ \\
- mesial nematotheca, diameter at rim & ca 15 & - \\
- lateral nematothecae, apophysis length & ca 75 & $70-80$ \\
- lateral nematothecae, length & ca 30 & $30-35$ \\
- lateral nematothecae, diameter at rim & & \\
\hline
\end{tabular}

piriform, tapering gradually below into an indistinct, laterally curved pedicel; distal end truncate, not fully formed.

\section{Remarks}

The present material is, with little doubt, conspecific with part of that originally assigned to S. elegans by Ansín Agís et al. (2016), as for instance the colony from SMIB 4, stn DW53 that displays a "spirallybuilt" appearance (see their fig. 6a) and "larger hydrothecae" (see their fig. 8c-d). Although these authors acknowledged that "the remaining characters are similar to the other examined colonies" of S. elegans, they refrained from separating it specifically.

However, when compared to all available specimens of $S$. elegans occurring in the present collections, the colony from sample MNHN-IK-2015-610 is comparatively more slender and decidedly lax, and, most importantly, displays a spiral arrangement of the hydrocladia-bearing branches around the stem; the latter is lightly fascicled for the proximal $2.5 \mathrm{~cm}$ of its length, while the remainder $(13 \mathrm{~cm}$ high) is composed of only two contiguous tubes. In S. elegans, the stems are fairly fascicled for nearly their whole length, with only the very tips of the colonies being monosiphonic, and their cladia-bearing branches of both rows are strictly coplanar (compare Fig. 9A and Fig. 9B).

The material MNHN-IK-2015-596, besides displaying shorter stem internodes (and consequently more closely-set cladia-bearing branches) compared to the holotype, has similar cladia (Fig. 10D-E). Due to the scarcity of the available specimens of $S$. helicoidalis sp. nov., its intraspecific variability could not be assessed properly. In order to avoid any possible identification error, these specimens are not selected as a paratype, despite one of them being provided with (immature) gonothecae.

\section{Distribution}

Known only from off New Caledonia (Ansín Agís et al. 2016; present study). 
Family Halopterididae Millard, 1962

Genus Antennella Allman, 1877

Antennella aff. varians (Billard, 1911)

Figs 11A, 12A-C, 13A-B; Table 4

Plumularia varians Billard, 1911: LXII, fig. 2.

Plumularia varians - Van Praët 1979: 930, fig. 72.

Antennella varians - Billard 1913: 11, fig. 4, pl. 1 figs 5, 8. — Bedot 1917: 116, 124; 1921a: 5. -

Hirohito 1969: 24, fig. 17; 1983: 59; 1995: 238, fig. 79d-g. - Schuchert 1997 (pro parte): 32,

figs 10, 11e-g. - Di Camillo et al. 2008: 1592, 1595. — Ansín Agís et al. 2009: 36, fig. 1.

Antenella varians - Ritchie 1913: 7. - Hirohito 1969: 24, fig. 17 (incorrect subsequent spelling).

non Antennella varians - Rees \& Vervoort 1987: 117, fig. 23c-d. — Schuchert 1997 (pro parte): 35, fig. 11a-d [= Antennella balei (Billard, 1911)].

\section{Material examined}

PACIFIC OCEAN 11 sterile colony, ca $10 \mathrm{~cm}$ high; off New Caledonia, stn CP4985; $20^{\circ} 49^{\prime} \mathrm{S}, 160^{\circ} 57^{\prime} \mathrm{E}$; 480-540 m; 10 Sep. 2017; KANADEEP leg.; MNHN-IK-2015-603.

\section{Additional material}

BALI SEA 1 sterile colony of Antennella balei (Billard, 1911), with stems up to $5 \mathrm{~cm}$ high; Indonesia, Bali Island; $8^{\circ} 21^{\prime} \mathrm{S}, 115^{\circ} 42^{\prime} \mathrm{E}$; $18.5 \mathrm{~m}$; 30 Jan. 2017; HRG-1337.

CELEBES SEA $\bullet 1$ sterile colony of true $A$. varians (Billard, 1911), with stems up to $3 \mathrm{~cm}$ high; Indonesia, Siladen Island; ${ }^{\circ} 37^{\prime} 35.1^{\prime \prime} \mathrm{N}, 124^{\circ} 48^{\prime} 7.4^{\prime \prime} \mathrm{E}$; 30-50 m; Jan. 2003; HRG-1584 • 1 fertile (monoecious) colony of A. balei (Billard, 1911), with stems up to $5.5 \mathrm{~cm}$ high; Indonesia, Derawan Archipelago, off Sangalaki Island; $2^{\circ} 05^{\prime} 21^{\prime \prime} \mathrm{N}, 118^{\circ} 24^{\prime} 04^{\prime \prime}$ E; 20 m; 23 Apr. 2010; HRG-0132.

FLORES SEA 1 fertile (monoecious) colony of A. balei (Billard, 1911), with stems up to $6 \mathrm{~cm}$ high; Indonesia, Alor Archipelago, Ternate Island, off Biatabang; 8¹3'26" S, 124²1'53" E; 15 m; 21 Oct. 2010; HRG-0546.

\section{Description}

Colony upright, ca $10 \mathrm{~cm}$ high, arising from elongated (2-3 cm high) mass of interlacing hydrorhizal fibers anchoring it in sediment, giving rise from its upper part to bundle of individual hydrocladia, all pointing upwards. Cladia up to $6 \mathrm{~cm}$ high, composed proximally of up to $1.5 \mathrm{~cm}$ long ahydrothecate part with two closely-set, parallel rows of frontal nematothecae, placed mostly alternately, occasionally in opposite pairs; ahydrothecate part ending in deeply-incised, oblique node, separated from remainder of cladium through prosegment, the latter also ending distally in oblique node; prosegment with hydrotheca and its five associated nematothecae (a mesial one and two pairs of laterals), as well as four additional nematothecae imperceptibly displaced laterally, left and right, along longitudinal axis of internode. Remainder of hydrocladium undivided, but equivalents of internodes with hydrotheca, its four associated nematothecae (two pairs of laterals), as well as row of 2-4 nematothecae above (commonly 3, but proximal 'internodes' with 4 of these, and distal 'internodes' with only 2). Hydrotheca cup-shaped, fully adnate, abaxial wall straight for most of its length, slightly curved inwardly at aperture; rim smooth, aperture circular, facing upwards. All nematothecae bithalamic and movable; mesial nematotheca indistinguishable morphologically from its counterparts situated proximally in row, all with slightly scooped rim of upper chamber; lateral nematothecae in pairs, first pair borne on tips of 
moderately-developed apophyses, second pair seated near bases of same apophyses; first pair greatly surpassing hydrothecal rim, with tall basal chamber, upper chamber shallow, conical, with rim entire; second pair comparatively shorter, wall of upper chamber scooped on adaxial side. Gonothecae absent.

\section{Remarks}

There is little doubt that the present material is conspecific with that described and illustrated earlier by Ansín Agís et al. (2009). Both display a single row of nematothecae between successive hydrothecae (except for the proximalmost internodes), and this represents a deviation from the current concept of A. varians (Billard, 1911), in which the nematothecae are arranged in two parallel rows, even though their distribution in pairs is not always met with (Billard 1913; present study). Additionally, a comparison of the material at hand with true specimens of $A$. varians from Indonesia (sample HRG-1584) reveals a series of discrete differences, such as the shape of the hydrotheca (compare Fig. 12B-C and 12D-E, respectively) and the size of the anterior pair of lateral nematothecae (compare Fig. 13B and 13C). Their morphometrical differences are summarized in Table 4. For these reasons, the New Caledonian material is provisionally assigned to the hydroid of Billard (1911), pending a more comprehensive morphological study based on a relevant number of colonies, as well as genetic data.

Billard (1913) distinguished his A. varians from A. balei (Billard, 1911) on the following accounts: 1) the proximal part of the stems always bears a prosegment in the former, but never in the latter; its occurrence was documented by a number of authors (e.g., Billard 1913: fig. 4a; Hirohito 1995: fig. 79d;
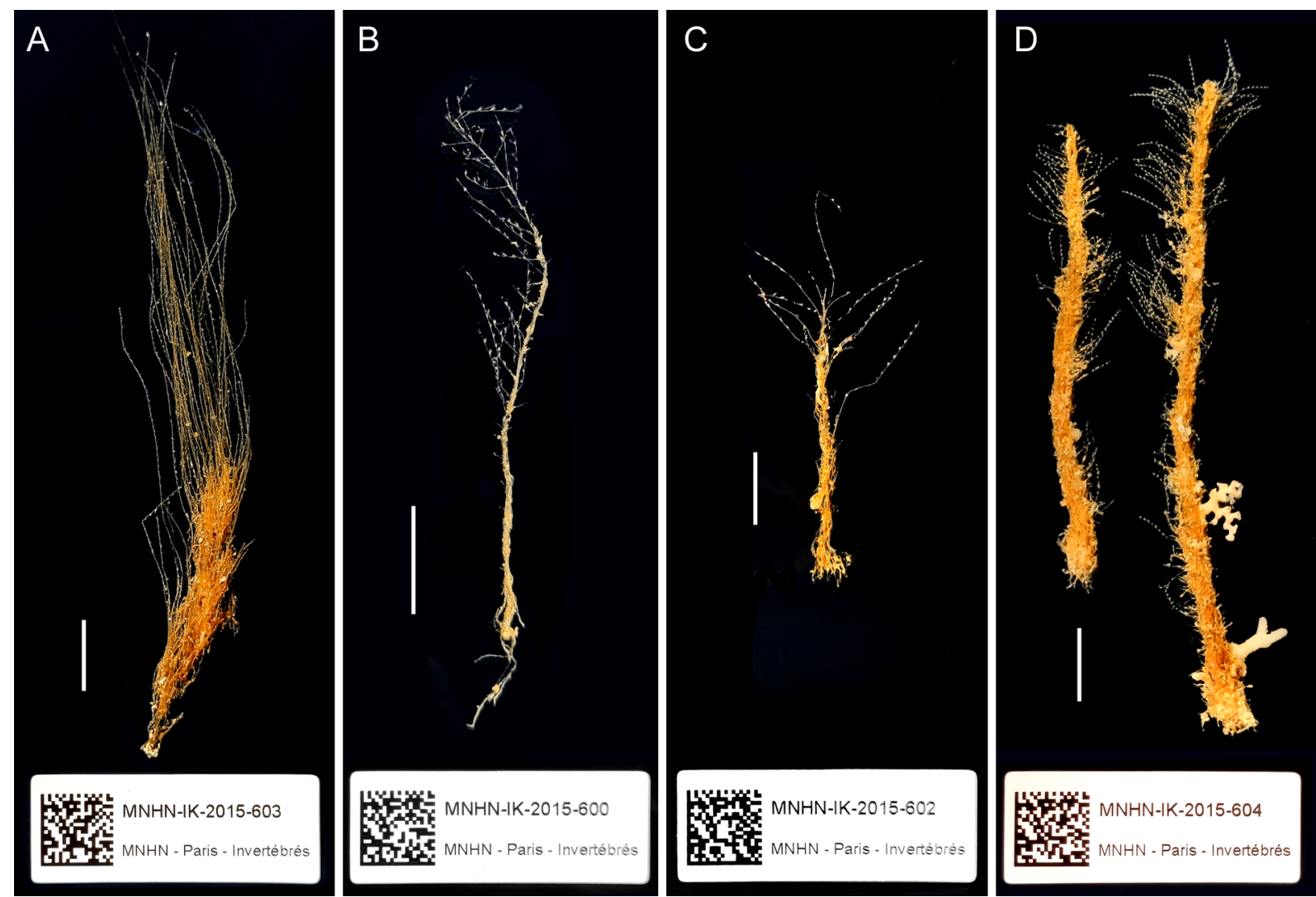

Fig. 11. A. Antennella aff. varians (Billard, 1911), colony, MNHN-IK-2015-603. - B. Corhiza megatheca (Ansín Agís et al., 2009), colony, MNHN-IK-2015-600. - C. Corhiza patula Galea sp. nov., holotype colony, MNHN-IK-2015-602. - D. Corhiza pauciarmata Ansín Agís et al., 2009, colony, MNHN-IK-2015-604. Scale bars: $1 \mathrm{~cm}$. 
Table 4. Measurements of Antennella aff. varians (Billard, 1911) vs true A. varians and A. balei (Billard, 1911), in $\mu \mathrm{m}$. "Di Camillo, pers. comm.

\begin{tabular}{|c|c|c|c|c|}
\hline & \multicolumn{2}{|c|}{ Antennella aff. varians (Billard, 1911) } & \multirow{2}{*}{$\begin{array}{c}\text { Antennella varians } \\
\text { (Billard, 1911) } \\
\\
\text { Present study, } \\
\text { HRG-1584 }\end{array}$} & \multirow{2}{*}{$\begin{array}{c}\begin{array}{c}\text { Antennella balei } \\
\text { (Billard, 1911) }\end{array} \\
\\
\text { Present study, } \\
\text { HRG-0546 }\end{array}$} \\
\hline & $\begin{array}{l}\text { Present study, } \\
\text { MNHN- } \\
\text { IK-2012-603 }\end{array}$ & $\begin{array}{c}\text { Ansín Agís } \\
\text { et al. (2009), } \\
\text { MUSORSTOM 5, } \\
\text { stn DC388 }\end{array}$ & & \\
\hline \multicolumn{5}{|l|}{ Internodes } \\
\hline - prosegment, length & $1270-1315$ & - & $815-1110$ & absent \\
\hline $\begin{array}{l}\text { - distance between } \\
\text { successive } \\
\text { hydrothecae }\end{array}$ & $810-865$ & $780-1300$ & $645-760$ & $460-520$ \\
\hline - diameter at node & $150-175$ & $140-210$ & $90-155$ & $155-190$ \\
\hline \multicolumn{5}{|l|}{ Hydrotheca } \\
\hline - abaxial wall, length & $325-365$ & $300-370$ & $300-360$ & $275-290$ \\
\hline - diameter at rim & $205-215$ & $180-250$ & $250-265$ & $175-190$ \\
\hline \multicolumn{5}{|l|}{ Nematothecae } \\
\hline $\begin{array}{l}\text { - lateral, } 1^{\text {st }} \text { pair, } \\
\text { apophysis length }\end{array}$ & $115-130$ & - & ca 60 & $160-170$ \\
\hline $\begin{array}{l}\text { - lateral, } 1^{\text {st }} \text { pair, } \\
\text { length }\end{array}$ & $200-225$ & $210-230$ & $135-165$ & ca 50 \\
\hline $\begin{array}{l}\text { - lateral, } 1^{\text {st }} \text { pair, } \\
\text { maximum width }\end{array}$ & $60-65$ & $55-60$ & $40-45$ & $60-65$ \\
\hline $\begin{array}{l}\text { - lateral, } 2^{\text {nd }} \text { pair, } \\
\text { length }\end{array}$ & $110-125$ & $110-130$ & $85-90$ & ca 50 \\
\hline $\begin{array}{l}\text { - lateral, } 2^{\text {nd }} \text { pair, } \\
\text { diameter at rim }\end{array}$ & ca 55 & $50-55$ & $40-45$ & $65-70$ \\
\hline $\begin{array}{l}\text { - of intersegment, } \\
\text { length }\end{array}$ & $110-125$ & $110-130$ & $100-105$ & $90-95$ \\
\hline $\begin{array}{l}\text { - of intersegment, } \\
\text { diameter at rim }\end{array}$ & ca 55 & $50-60$ & $45-55$ & ca 70 \\
\hline \multicolumn{5}{|l|}{ Male gonotheca } \\
\hline - length w/o pedicel & - & $540-600$ & ${ }^{*} 600-630$ & $405-485$ \\
\hline - maximum width & - & $230-310$ & ${ }^{*} 195-220$ & $220-260$ \\
\hline - diameter at aperture & - & - & *ca 75 & $55-70$ \\
\hline \multicolumn{5}{|l|}{ Female gonotheca } \\
\hline - length w/o pedicel & - & $850-900$ & "550-600 & $595-695$ \\
\hline - maximum width & - & $370-440$ & *275-330 & $325-350$ \\
\hline - diameter at aperture & - & - & ${ }^{*} 170-190$ & $190-210$ \\
\hline
\end{tabular}

Fig. 12 (opposite page). A-C. Antennella aff. varians (Billard, 1911) from sample MNHN-IK-2015-603, proximal part of cladium showing prosegment (A), and comparison with counterpart of A. balei (Billard, 1911) (F); hydrotheca in frontal view (B) compared to hydrothecae of true A. varians (D) and A. balei (G); hydrotheca in lateral view (C) compared to hydrothecae of true A. varians (E) and A. balei from various samples (H-J). A-C from sample MNHN-IK-2015-603; D-E from sample HRG-1584; F-H from sample HRG-1337; I from sample HRG-0546; J from sample HRG-0132; Scale bars: A, F = 1 mm; B-E, G-J $=200 \mu \mathrm{m}$. 


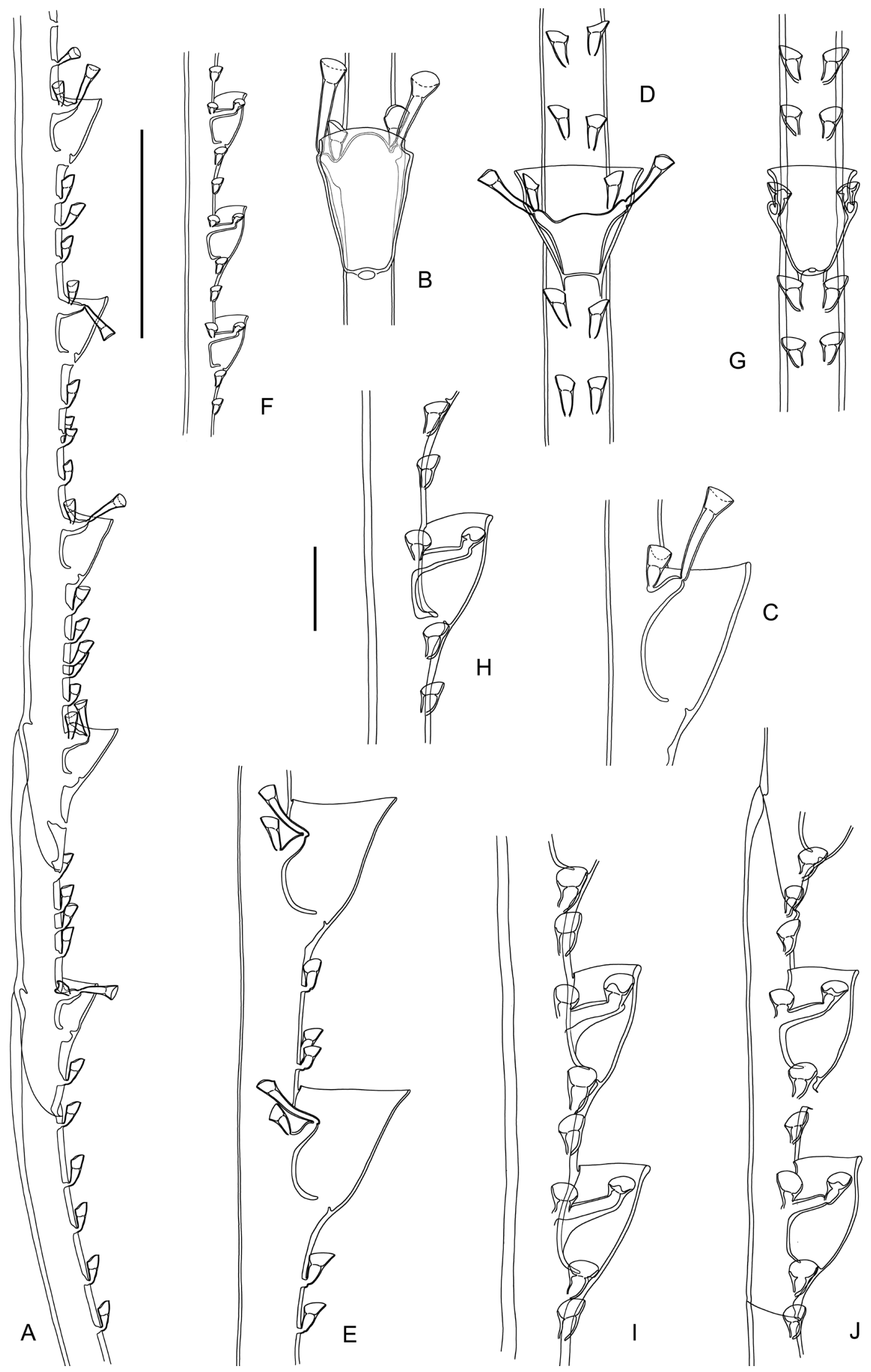


present study);2) the frontal pair of lateral nematothecae is borne on moderately-developed apophyses, unlike in $A$. balei where these apophyses are comparatively longer, stubby, and fused to the hydrothecal wall; 3) the anterior pair of lateral nematothecae is trumpet-shaped instead of being short and conical, and possesses wide apertures.

In spite of the opinion of Schuchert (1997), A. balei is here kept distinct from A.varians. Indeed, the examination of several samples from three distant localities in Indonesia reveals a uniformity of morphological characters: 1) although deeply-incised, strongly oblique nodes occur here and there along the stems, delimiting internodes with numerous hydrothecae, a prosegment is lacking in all specimens; 2) the proximal part of each stem $( \pm 1 \mathrm{~cm}$ long) bears a varied number of hydrothecae until the first strongly oblique node occurs; in some specimens, this portion could be segmented by slightly oblique nodes into internode bearing irregularly $1,2,3$, etc. hydrothecae; these nodes, although distinct, are neither that deeply-incised, nor that strongly oblique as the scarce nodes that occasionally divide the caulus above; 3 ) there is no single mesial nematotheca, even in the internodes immediately above a deeply-incised, strongly-oblique node; 4) there are generally 2 pairs (occasionally 3 proximally) of nematothecae in two parallel rows above each hydrotheca, the members of each pair being always situated at the same level; 5) a deeply-incised, strongly-oblique node generally passes through two consecutive pairs of stem nematothecae, one being confined to the internode below, the other to the internode above; 6) all nematothecae have a hypertrophied perisarc; the first pair of laterals is borne on long, horizontal apophyses fused to the lateral walls of the hydrotheca; the second pair is sessile, and the nematothecae have a size comparable to their anterior counterparts; the wall of the upper chamber of the anterior nematothecae is sinusoid on the adaxial side.

Antennella biarmata Nutting, 1927 is very likely a junior synonym of $A$. balei, judging from the shape and size of the apophysis supporting the lateral nematothecae, and additional characters mentioned in the original account.

The material assigned by Rees \& Vervoort (1987) to A. varians could not be allocated with certainty to either $A$. varians or $A$. balei, due to an unusual segmentation of the stems and some characters displayed by the nematothecae.

\section{Distribution}

Indonesia (Billard 1913; Di Camillo et al. 2008), Japan (Hirohito 1995), New Caledonia (Ansín Agís et al. 2009; present study).

Genus Corhiza Millard, 1962

Corhiza megatheca (Ansín Agís et al., 2009)

Figs $11 \mathrm{~B}, 13 \mathrm{H}-\mathrm{J}$; Table 5

Antennella megatheca Ansín Agís et al., 2009: 39, fig. 3.

\section{Material examined}

PACIFIC OCEAN 11 sterile colony, ca $7 \mathrm{~cm}$ high; off New Caledonia, stn DW4725; $22^{\circ} 41^{\prime} \mathrm{S}, 167^{\circ} 05^{\prime} \mathrm{E}$; 240-256 m; 20 Aug. 2016; KANACONO leg.; MNHN-IK-2015-595 • 1 ca 5 cm high, fertile colony;

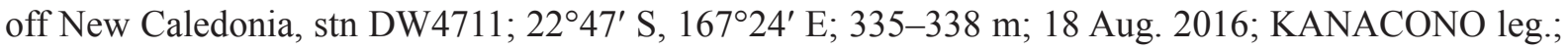
MNHN-IK-2015-600.

\section{Description}

Relatively flaccid, upright colonies, reaching as much as $7 \mathrm{~cm}$ in height, arising from rhizoid stolon securing the whole into sediment. Stem fascicled for most of its length, becoming monosiphonic 
distally; accessory tubes tortuous, anastomosing, devoid of nematothecae; main tube almost straight, unsegmented, athecate, giving rise at more or less regular intervals to short hydrocladial apophyses springing in all directions around stem; occasionally two apophyses are given off at the same level; apophyses ending in straight nodes distally. Cladia up to $1.1 \mathrm{~cm} \mathrm{long}$, heteromerously segmented by alternating straight and oblique nodes; first segment relatively short, delimited by straight nodes at both ends, with distally-placed nematotheca at its upper side; remainder of hydrocladium with regular structure, composed of alternating ahydro- and hydrothecate internodes. Ahydrothecate internodes comparatively longer than their hydrothecate counterparts, with proximal node transverse and distal node oblique; first internode exceedingly long, with 4-6 frontal nematothecae in row, subsequent ones shorter and provided with 2 frontal nematothecae, length of internodes decreasing distally, so that only 1 nematotheca is to be found on them. Hydrothecate internodes with proximal node oblique and distal node transverse, with one hydrotheca and its three associated nematothecae: a mesial one, not reaching the hydrothecal base, and pair of relatively short laterals, borne on moderately-long apophyses, together reaching half-length the adnate wall of hydrotheca. Hydrothecae very deep, tubular, somehow flared at margin, rim circular, entire. Gonothecae borne on cladia, given off singly from lateral side of hydrothecate internode, between hydrothecal basis and mesial nematotheca; pedicel of two short, quadrangular, athecate segments; gonotheca large, piriform, thin-walled, tapering basally and provided there with 3 nematothecae; aperture apical, ovoid, provided with watch-glass-shaped operculum. All nematothecae bithalamic, conical, upper chamber shorter than basal one, with rim scooped on both aband adaxial sides, distinctly more on the latter.

\section{Remarks}

There is little doubt that the present materials belong to the same species as that described by Ansín Agís et al. (2009) under the basionym Antennella megatheca. The morphology of their trophosomes, as well as their measurements (see Table 5), agree well. It is likely that these authors had only tips of colonies, not exceeding $13 \mathrm{~mm}$ in length, that were provided with a limited number of cladia. This prompted them to consider the distal, monosiphonic parts of the main stems as representing potential stolons.

No fertile specimens were reported so far, but the colony from sample MNHN-IK-2015-600 bears gonothecae.

Corhiza megatheca is unique among its congeners in that its cladia, instead of being given off from the component tubes of the stem, arise from a single, main tube, while all other counterparts have a strictly accessory function. This particular condition raises the question of the generic limitation in Corhiza Millard, 1962. At least morphologically speaking, the genus appears to be polyphyletic, with several species not meeting the original scope defined by Millard (1962: 275), viz, "fascicled stem composed of a number of interwoven and intercommunicating tubes of equal diameter and importance. Hydrocladia arising from the component tubes in a completely irregular fashion, not rebranching". Indeed, C. sociabilis Millard, 1980 is a branched species with a pinnate appearance, in which three types of component tubes have been identified: 1) one to several axial tubes, each branched or unbranched; tubes bearing alternate cladia; 2) companion tubes, provided with hydrothecae, that accompany each branch; 3) peripheral tubes carrying nematothecae only (Millard 1980). Another species, formerly known as C. valdiviae (Stechow, 1923) (Millard 1975) is shown to belong to the new genus, Thamnopteros Galea gen. nov. (see below).

For the time being, it is preferred to leave provisionally the present species in Corhiza, until additional data at both specific and generic levels become available.

\section{Distribution}

Known only from off New Caledonia (Ansín Agís et al. 2009; present study). 

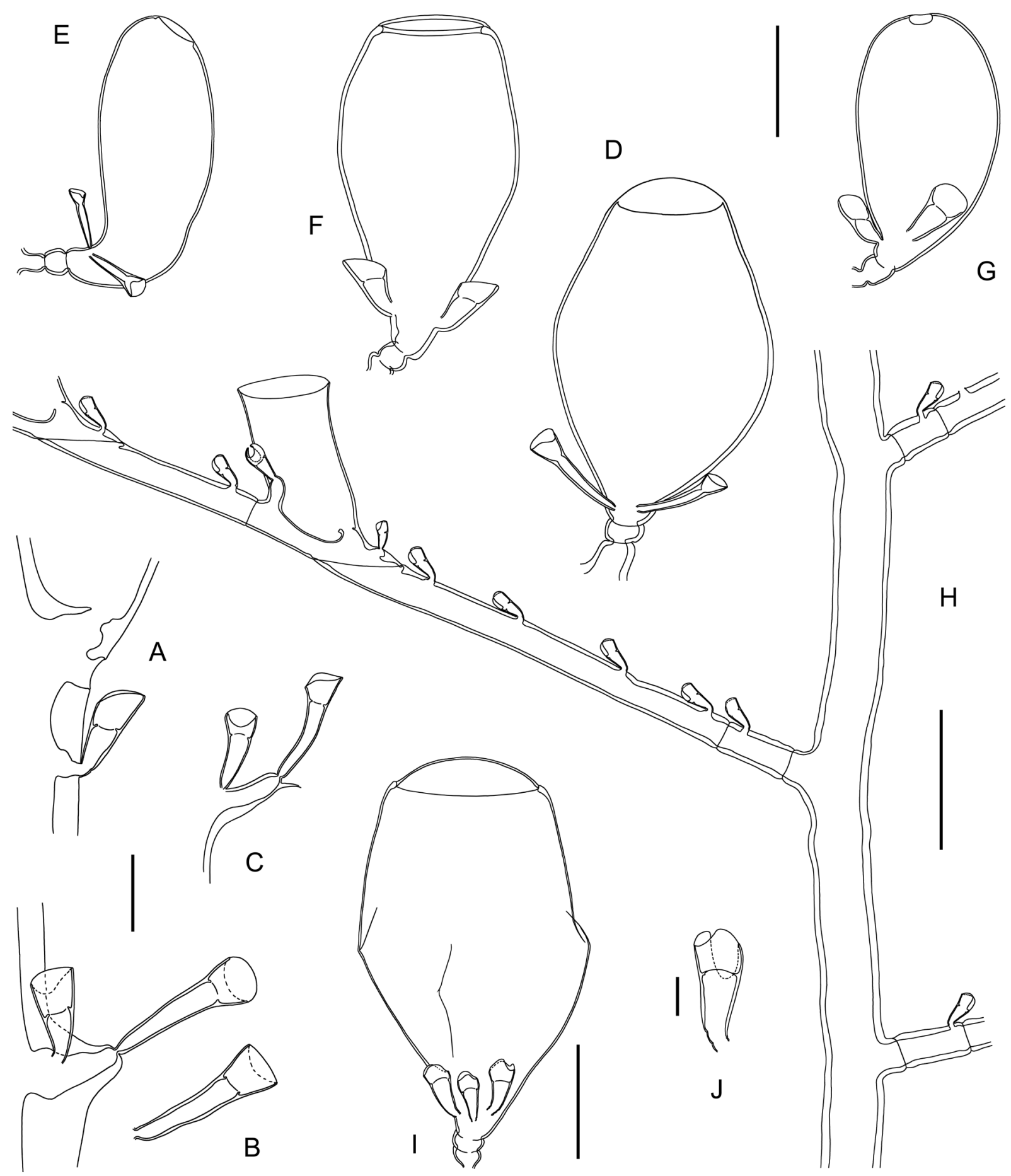

Fig. 13. A-B. Antennella aff. varians (Billard, 1911), cauline nematotheca (A); lateral nematothecae (B) compared to those of the true $A$. varians (C); female (D) and male (E) gonothecae of true A. varians compared to their counterparts from A. balei (F-G, respectively). D-E from sample HRG-1584; F-G from sample HRG-0546. - H-J. Corhiza megatheca (Ansín Agís et al., 2009), distal, monosiphonic portion of stem with three successive cladial apophyses and proximal part of a cladium $(\mathrm{H})$, from sample MNHN-IK-2015-595; gonotheca (I) and detail of one of its basal nematothecae (J), from sample MNHN-IK-2015-600. Scale bars: A-C $=100 \mu \mathrm{m} ; \mathrm{D}-\mathrm{G}=200 \mu \mathrm{m} ; \mathrm{H}=500 \mu \mathrm{m} ; \mathrm{I}=300 \mu \mathrm{m} ; \mathrm{J}=50 \mu \mathrm{m}$. 
Table 5. Measurements of Corhiza megatheca (Ansín Agís et al., 2009), in $\mu \mathrm{m}$.

\begin{tabular}{|c|c|c|c|}
\hline & $\begin{array}{l}\text { Present study, } \\
\text { MNHN-IK-2015-600 }\end{array}$ & $\begin{array}{c}\text { Ansín Agís et al. } \\
\text { (2009), BIOCAL } \\
\text { stn DW38 }\end{array}$ & $\begin{array}{l}\text { Ansín Agís et al. } \\
\text { (2009), BIOCAL } \\
\text { stn DW41 }\end{array}$ \\
\hline \multicolumn{4}{|l|}{ Internodes } \\
\hline - $1^{\text {st }}$ ahydrothecate & $175-335$ & - & - \\
\hline - regular ahydrothecate & $420-785$ & $590-700$ & $560-790$ \\
\hline - hydrothecate & $500-540$ & $450-590$ & $470-600$ \\
\hline \multicolumn{4}{|l|}{ Hydrotheca } \\
\hline - free adaxial wall, length & $435-490$ & $330-410$ & $370-470$ \\
\hline - adnate adaxial wall, length & $300-400$ & - & - \\
\hline - abaxial wall, length & $570-685$ & $370-610$ & $500-690$ \\
\hline - diameter at rim & $320-380$ & $260-320$ & $310-360$ \\
\hline \multicolumn{4}{|l|}{ Gonotheca } \\
\hline - length, without pedicel & ca 1000 & - & - \\
\hline - maximum width & ca 600 & - & - \\
\hline - diameter at aperture & ca 370 & - & - \\
\hline
\end{tabular}

Corhiza patula Galea sp. nov.

urn:1sid:zoobank.org:act:FDCDC082-2435-4268-8808-C5B7D74D7BEB

Figs 11C, 14A-D; Table 6

\section{Diagnosis}

Stem composed of many loosely-aggregated tubes arising from root-like hydrorhiza; individual cladia arising distally, in all directions, from some of the component tubes; proximal parts of cladia with a row of frontal, bithalamic nematothecae; distal node oblique, followed by a regular succession of alternating hydrothecate and ahydrothecate internodes delimited by a heteromerous segmentation; ahydrothecate internodes short, with a frontal nematotheca proximally; hydrothecate internodes equally short, with a very deep, cylindrical hydrotheca with strongly flared margin, and its 3 associated nematothecae: one mesial, and a pair of lateral; mesial nematotheca with wall of upper chamber lowered adaxially; lateral nematothecae borne on short apophyses, upper chamber globular, with deeply emarginated wall on adaxial side. Gonothecae unknown.

\section{Etymology}

From Latin 'pātǔlus, $-a$, -um', meaning 'provided with a wide aperture', to illustrate the shape of its hydrothecae.

\section{Material examined}

Holotype

PACIFIC OCEAN $\bullet 1$ sterile colony, ca 5 cm high; off New Caledonia, stn DW4746; 22 $59^{\prime}$ S, $167^{\circ} 43^{\prime}$ E; 508-494 m; 23 Aug. 2016; KANACONO leg.; MNHN-IK-2015-602.

\section{Description}

Colony upright, ca $5 \mathrm{~cm}$ high, arising from dense, root-like hydrorhiza, composed of numerous branching, anastomosing tubes that converge, then loosely aggregate above substrate to form ca $3 \mathrm{~cm}$ high, fascicled stem; all tubes have equivalent roles; division into internodes absent; perisarc thick, smooth to slightly wrinkled. Some of component tubes of stem modified distally to become cladia; these detach from 
Table 6. Measurements of Corhiza patula Galea sp. nov., in $\mu \mathrm{m}$.

\begin{tabular}{lc}
\hline & MNHN-IK-2015-602 \\
\hline Internodes & \\
- ahydrothecate, length & $550-760$ \\
- hydrothecate, length & $580-650$ \\
- diameter at node & $100-140$ \\
Hydrotheca & \\
- free adaxial wall, length & $355-385$ \\
- adnate adaxial wall, length & $440-485$ \\
- abaxial wall, length & $695-810$ \\
- diameter at rim & $420-475$ \\
Nematothecae & \\
- mesial, length & $120-140$ \\
- mesial, diameter at rim & $90-115$ \\
- lateral, apophysis length & $75-90$ \\
- lateral, length & $150-170$ \\
- lateral, width of upper chamber & ca 45 \\
- of intersegment, length & $120-190$ \\
- of intersegment, diameter at rim & $60-105$ \\
\hline
\end{tabular}

stem at acute angle, pointing upwards, in all directions around it. Cladia up to $2 \mathrm{~cm}$ long, composed of free, ahydrothecate proximal part with smooth perisarc, occasionally with either signs of breakage followed by subsequent regeneration, or divided by transverse nodes into succession of internodes of varied length, distally bearing row of nematothecae; last internode with oblique node distally; remainder of cladium heteromerously segmented into hydrothecate and ahydrothecate internodes by means of alternating transverse and oblique nodes; most often, transverse node only slightly indicated, especially dorsally; oblique nodes generally well-marked, though here and there they may be totally absent. Hydrothecate internodes short, with proximally oblique and distally transverse nodes, a hydrotheca and its three associated nematothecae: one mesial and pair of laterals; hydrotheca thin-walled, deep, tubular, half adnate, flaring distinctly at aperture; mesial nematotheca not reaching hydrothecal base, upper chamber with rim lowered on adaxial side; lateral nematothecae borne on short apophyses, whole structure far from reaching hydrothecal margin; upper chamber globular, with rim distinctly scooped on adaxial side. Ahydrothecate internodes with proximal node transverse and distal node oblique, of nearly same length as their hydrothecate counterparts; proximally frontal, conical nematotheca with rim of upper chamber lowered on adaxial side. Gonothecae absent.

Fig. 14 (opposite page). A-D. Corhiza patula Galea sp. nov., from holotype MNHN-IK-2015-602, proximal portion of cladium (A); nematothecae: mesial (B), lateral (C), and from ahydrothecate internode (D). - E-J. Corhiza pauciarmata Ansín Agís et al., 2009, from sample MNHN-IK-2015-604, portion of cladium (E); nematothecae: mesial (F), lateral $(\mathrm{G})$ and from ahydrothecate internode in lateral $(\mathrm{H})$ and adaxial (I) aspects; cnidome (J). - K. Halopteris campanula (Busk, 1852), portion of cladium from sample MNHN-IK-2015-597. - L-M. Halopteris infundibulum Vervoort, 1966, cladial hydrotheca in lateral (L) and frontal (M) aspects, both from sample MNHN-IK-2015-608. - N-P. Halopteris peculiaris Billard, 1913, proximal portion of cladium seen laterally $(\mathrm{N})$; single $(\mathrm{O})$ or paired $(\mathrm{P})$ lateral nematothecae associated to cauline hydrothecae; all from sample MNHN-IK-2015-609. Scale bars: A, $\mathrm{E}=500 \mu \mathrm{m} ; \mathrm{B}-\mathrm{D}, \mathrm{F}-\mathrm{I}, \mathrm{O}-\mathrm{P}=100 \mu \mathrm{m} ; \mathrm{J}=10 \mu \mathrm{m} ; \mathrm{K}-\mathrm{N}=300 \mu \mathrm{m}$. 


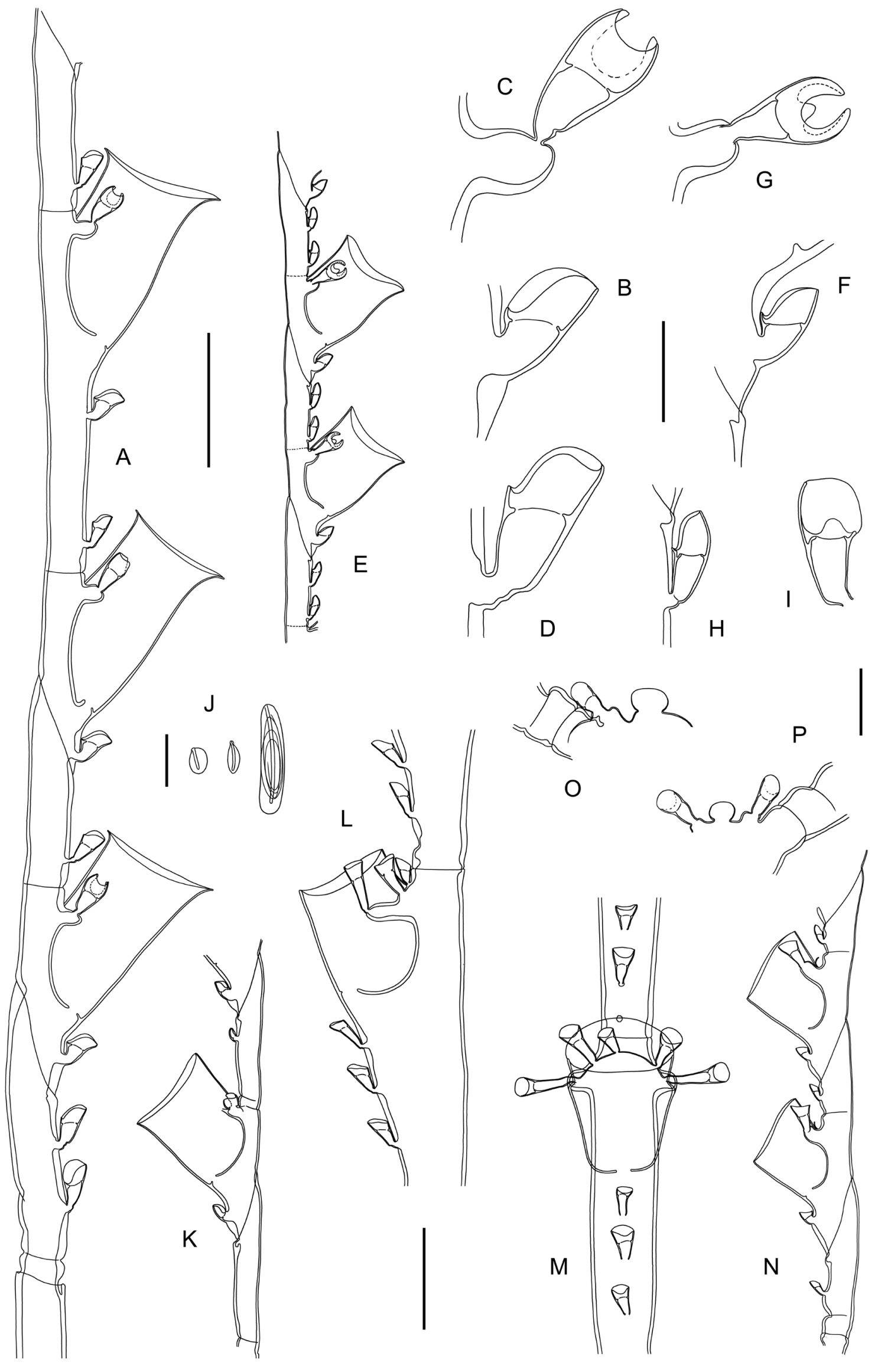




\section{Remarks}

Corhiza patula Galea sp. nov. is unique among its congeners through the distinctive shape and size of its hydrothecae. Only the hydrothecae of C. megatheca, if this species proves congeneric, approach their morphology, but they are slightly smaller and not distinctly flared at rim. Unlike in the new species, it has been shown above that the cladia of $C$. megatheca are given off exclusively from a single tube of the fascicled stem. The third species occurring in the study area, C. pauciarmata Ansín Agís et al., 2009 (see below), has comparatively shorter hydrothecae (compare Fig. 14A and 14E).

Other congeners are immediately distinguished from C. patula Galea sp. nov. through the following features: 1) the hydrothecae of C. bellicosa Millard, 1962 are adnate for most of their length (Millard 1962); 2) two pairs of lateral nematothecae occur in C. pannosa Millard, 1962 (original account), C. scotiae (Ritchie, 1907) (Vervoort \& Watson 2003), C. sociabilis Millard, 1980 (original account) and C. splendens Vervoort \& Watson, 2003 (original account); 3) an axillar nematotheca is found behind the hydrothecae of C. complexa (Nutting, 1905) (Schuchert 1997).

\section{Distribution}

Known only from off New Caledonia (present study).

Corhiza pauciarmata Ansín Agís et al., 2009

Figs 11D, 14E-J; Table 7

Corhiza pauciarmata Ansín Agís et al., 2009: 56, fig. 11.

\section{Material examined}

PACIFIC OCEAN $\cdot 2$ sterile colonies, 6 and $9 \mathrm{~cm}$ high, respectively, with only remains of hydrorhiza; off New Caledonia, stn DW4741; 22 ${ }^{\circ} 52^{\prime}$ S, 167²1' E; 210-210 m; 23 Aug. 2016; KANACONO leg.; barcode identifier MT655153; MNHN-IK-2015-604.

\section{Description}

Colonies upright, up to $9 \mathrm{~cm}$ high, with strongly fascicled stems, ca $4 \mathrm{~mm}$ thick basally, most probably arising from rhizoid stolons. Cladia numerous, up to $1.2 \mathrm{~cm}$ long, given off irregularly from component tubes of stem; transverse constriction short distance above origin; proximal part ahydrothecate, with few occasional transverse nodes or signs of breakage and subsequent regeneration, with row of frontal nematothecae, distally ending in oblique node; remainder of stem heteromerously segmented, with alternating thecate and ahydrothecate internodes, both short. Thecate internodes, up to 12 per cladium, barely accommodating a hydrotheca and its 3 associated nematothecae: a mesial one and pair of laterals; mesial nematotheca immovable, with rim of upper chamber lowered adaxially; lateral nematothecae borne on short apophyses, with globular upper chamber whose abaxial wall is deeply scooped, adopting marked sinusoid shape adaxially. Athecate internodes with two frontal nematothecae in row; upper chamber with rim distinctly emarginated on adaxial side, often sinusoid. Gonothecae absent. Cnidome composed of three types of heteronemes: 1) seed-shaped, $(4.8-5.1) \times(3.1-3.3) \mu \mathrm{m} ; 2)$ banana-shaped, $(6.4-6.6) \times(2.5-2.6) \mu \mathrm{m} ; 3)$ elongated-ovoid, $(20.9-23.1) \times(4.6-5.1) \mu \mathrm{m}$.

\section{Remarks}

Although the ahydrothecate internodes of cladia are comparatively shorter, no other differences could be noted with the specimens described and illustrated by Ansín Agís et al. (2009).

\section{Distribution}

Scattered records from off New Caledonia (Ansín Agís et al. 2009; present study). 
Table 7. Measurements of Corhiza pauciarmata Ansín Agís et al., 2009, in $\mu \mathrm{m}$.

\begin{tabular}{lcc}
\hline & $\begin{array}{c}\text { Present study, } \\
\text { MNHN-IK-2015-604 }\end{array}$ & $\begin{array}{c}\text { Ansín Agís } \text { et al. (2009), } \\
\text { SMIB 4 stn DW55 }\end{array}$ \\
\hline Internodes & & \\
- ahydrothecate, length & $335-355$ & $450-700$ \\
- hydrothecate, length & $300-320$ & $370-420$ \\
- diameter at node & $80-90$ & $60-90$ \\
Hydrotheca & & \\
- free adaxial wall, length & $205-215$ & $240-270$ \\
- adnate adaxial wall, length & $205-215$ & - \\
- abaxial wall, length & $315-350$ & $310-370$ \\
- diameter at rim & $270-295$ & $260-310$ \\
Nematothecae & & \\
- mesial, length & $90-95$ & $70-80$ \\
- mesial, diameter at rim & ca 60 & $35-40$ \\
- lateral, apophysis length & $55-60$ & - \\
- lateral, length & $125-140$ & $110-130$ \\
- lateral, width of upper chamber & $65-70$ & $60-70$ \\
- of intersegment, length & $90-100$ & $60-90$ \\
- of intersegment, diameter at rim & $40-45$ & $30-35$ \\
\hline
\end{tabular}

Genus Halopteris Allman, 1877

Halopteris campanula (Busk, 1852)

Figs $14 \mathrm{~K}, 15 \mathrm{~A}-\mathrm{B}$

Halopteris campanula - Ansín Agís et al., 2009: 43, figs 5-6.

\section{Material examined}

PACIFIC OCEAN - 1 profuse, fertile colony with stems up to $4.5 \mathrm{~cm}$ high; off New Caledonia, stn DW4780; 22 ${ }^{\circ} 59^{\prime}$ S, $167^{\circ} 48^{\prime}$ E; 295-238 m; 29 Aug. 2016; KANACONO leg.; MNHN-IK-2015-597 • 3 fully fertile colonies, with stems up to $4 \mathrm{~cm}$ high; off New Caledonia, stn DW4781; $22^{\circ} 57^{\prime} \mathrm{S}, 167^{\circ} 47^{\prime} \mathrm{E}$; 295-255 m; 29 Aug. 2016; KANACONO leg.; MNHN-IK-2015-598 • 1 sterile colony, 3 cm high; off

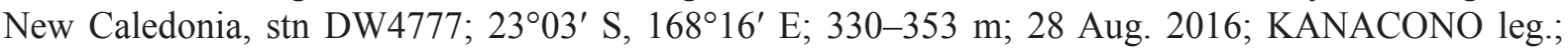
MNHN-IK-2015-599 1 profuse, fully fertile colony with stems up to $4.5 \mathrm{~cm}$ high; off New Caledonia,

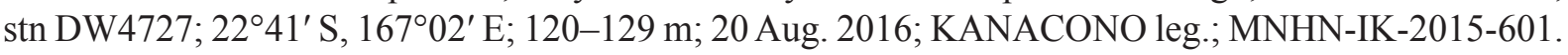

\section{Remarks}

For synonymies and descriptions, see Rees \& Vervoort (1987), Schuchert (1997) and Ansín Agís et al. (2009). The present material agrees with that dealt with extensively by the latter authors.

\section{Distribution}

Scattered records from the Red Sea, the Gulf of Aden, Indonesia, Australia, Japan, and New Caledonia (Ansín Agís et al. 2009).

Halopteris infundibulum Vervoort, 1966

Figs 14L-M, 15C

Halopteris infundibulum Vervoort, 1966: 133, fig. 36. 
Halopteris infundibulum - Schuchert 1997: 121, fig. 44. — Vervoort \& Watson 2003: 359, fig. 87c-j. Ansín Agís et al. 2009: 51, fig. 8.

\section{Material examined}

PACIFIC OCEAN $\cdot 2$ stems, both ca $8 \mathrm{~cm}$ high, 1 bearing a (damaged) gonotheca; off New Caledonia, stn DW5026; 2022' S, 158 40’ E; 360-410 m; 21 Sep. 2016; KANADEEP leg.; MNHN-IK-2015-608.

\section{Description}

Stems upright and quite rigid, simple, monosiphonic, ca $8 \mathrm{~cm}$ high, arising from reticulate hydrorhiza; composed of long $(5-6 \mathrm{~cm})$ proximal part devoid of hydrothecae and hydrocladia, and comparatively shorter $(2-3 \mathrm{~cm})$ distal part bearing hydrothecae and hydrocladia. Proximal part with few closely-set transverse nodes immediately above origin from stolon, as well as few, irregular, more distant ones above; nematothecae in two closely-set, longitudinal rows, only in distal part of this portion of stem; nematothecae alternate along most length of nematothecate part of stem, distalmost ones being gradually arranged in subopposite to opposite pairs. Upper part of stem starting with two consecutive prosegments delimited at both ends by deeply-incised, very oblique nodes, each comprising a proximally-placed, quite damaged hydrotheca, 11 nematothecae, and cladial apophysis arising only from side of second hydrotheca; nematothecae: one mesial, two pairs of laterals, as well as 3 opposite pairs above hydrotheca, in two closely-set, longitudinal rows. Remainder of stem slightly geniculate, with faintly-marked to almost imperceptible segmentation through slightly oblique nodes; each internode with hydrotheca proximally, short cladial apophysis laterally, and at least 9 nematothecae: one mesial, two pairs of laterals and 2 pairs above hydrotheca; presence of axillar nematotheca could not be checked properly, for cladial apophyses being shifted on to anterior part of stem, forming acute angle between two rows. Cladia up to $5 \mathrm{~mm}$
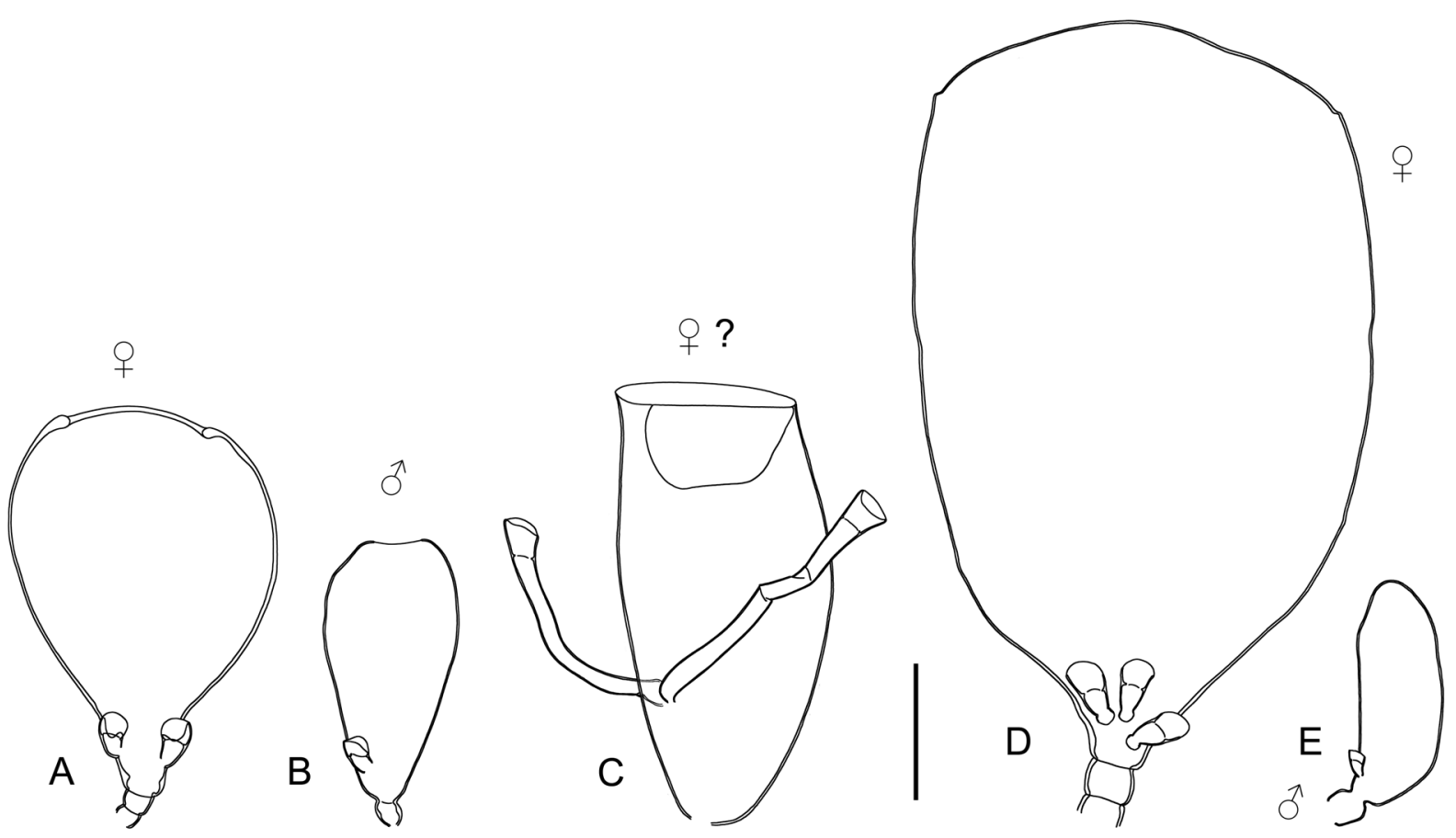

Fig. 15. A-B. Halopteris campanula (Busk, 1852), female (A) and male (B) gonothecae from samples MNHN-IK-2015-598 and MNHN-IK-2015-597, respectively. - C. Halopteris infundibulum Vervoort, 1966, possible female gonotheca, from sample MNHN-IK-2015-608. - D-E. Halopteris peculiaris Billard, 1913, female (D) and male (E) gonothecae, both from sample MNHN-IK-2015-609. Scale bar: $300 \mu \mathrm{m}$. 
long, bearing up to 11 hydrothecate internodes; proximally short, almost indistinct, athecate internode, with proximal node straight and distal node oblique; nodes on remainder of cladium generally indistinct but, when present, transverse, immediately above each hydrotheca; each internode with hydrotheca, flanked by double pair of nematothecae, as well as 3-4 additional nematothecae above; anterior pair of laterals borne on conspicuous apophyses, thecae projecting above hydrothecal rim; posterior pair sessile, at base of apophyses supporting anterior pair; proximalmost nematotheca among those situated between consecutive hydrothecae always situated behind adaxial wall of proximal hydrotheca, either decidedly in axil or certain distance above. All nematothecae conical, bithalamic, wall of upper chamber slightly lowered on adaxial side. Hydrotheca tubular, rather deep, $2 / 3^{\text {rd }}$ adnate, abaxial wall straight or nearly so, aperture circular, forming an angle of ca $40^{\circ}$ with internode. Single gonotheca arising laterally from below basis of cladial hydrotheca; urn-shaped, slightly flattened, tapering abruptly basally, distally truncate, and there provided with ovoid, deciduous, filmy flap; two exceedingly long nematothecae inserted at above $1 / 3^{\text {rd }}$ of its length.

\section{Remarks}

The present material agrees generally well with the type (Vervoort 1966; Schuchert 1997) and specimens examined by Vervoort \& Watson (2003) and Ansín Agís et al. (2009), although it shows a number of differences: 1) it bears 2 opposite pairs of nematothecae above the cauline hydrothecae, while the occurrence of only two nematothecae in a row has been documented previously; 2) there are 3-4 nematothecae, instead of only two as documented earlier, between two successive cladial hydrothecae, of which the proximalmost can be either decidedly axillar or situated a short distance above the axil; 3) the gonotheca is urn-shaped and not piriform, as described by Vervoort \& Watson (2003), and bears 2 exceedingly long nematothecae.

I can see little reason to separate specifically the present material from that described earlier, as the species is still poorly-known, and the intraspecific variation insufficiently documented. The gonotheca in my material could belong to the opposite sex with respect to that described earlier by Vervoort \& Watson (2003); as to the length of the nematothecae it carries, this could likely not be used as a valid taxonomic criterion at this stage, given that, in this hydroid, at least the lateral nematothecae display a "very variable" length (Vervoort \& Watson 2003).

\section{Distribution}

Tasman Sea (Vervoort 1966), New Zealand (Vervoort \& Watson 2003), New Caledonia (Ansín Agís et al. 2009; present study).

Halopteris peculiaris Billard, 1913

Figs $14 \mathrm{~N}-\mathrm{P}, 15 \mathrm{D}-\mathrm{E}$

Halopteris peculiaris - Schuchert 1997: 84, figs 29-30.

\section{Material examined}

PACIFIC OCEAN 1 colony composed of a few fertile stems, up to $6 \mathrm{~cm}$ high; off New Caledonia, stn DW4774; 2301' S, $168^{\circ} 19^{\prime}$ E; 100-90 m; 28 Aug. 2016; KANACONO leg.; MNHN-IK-2015-609.

\section{Remarks}

For synonymy and a description, refer to Schuchert (1997).

In the present material, the lateral nematothecae associated to the cauline hydrothecae on the side opposite to the cladial apophyses are often absent (Fig. 14O); in only rare instances, a pair is formed (Fig. 14P). The cladia display a regular structure: they begin with a short, quadrangular, athecate segment, followed 
by an ahydrothecate internode bearing a superior nematotheca and ending distally in an oblique node; afterwards, the segmentation is heteromerous, with up to 8 hydrothecate internode alternating with ahydrothecate counterparts (Fig. 14N); the latter are short, delimited proximally by a transverse node and distally by an oblique node, and bear a frontal nematotheca; the hydrothecate internodes are slightly longer, are delimited proximally by an oblique node and distally by a transverse one, and bear distally a hydrotheca and its 4 associated nematothecae: a mesial, a pair of laterals, and a scale-shaped axillar one. There is an important sexual dimorphism of the gonothecae: the female, given off from below the cauline hydrothecae, are large, ovoid and bear proximally 3 nematothecae (Fig. 15D); the male gonothecae, borne on cladia, are comparatively minute, and bear a single basal gonotheca (Fig. 15E).

\section{Distribution}

North Ubian Island, Philippines (Billard 1913), Lizard Island, Australia (Schuchert 1997), South Africa [Millard 1975, as Halopteris glutinosa (Lamouroux, 1816)].

Genus Monostaechas Allman, 1877

Monostaechas fisheri Nutting, 1905

Figs 16A, 17A-I, 18; Table 8

Monosteachas fisheri Nutting, 1905: 952, pl. 5 fig. 3, pl. 12 fig. 8.

Monostaechas fisheri-Bedot 1921a: 6. — Stechow 1925: 252, 253. — Vervoort 1968: 64. — Migotto 1996: 50-51. — Schuchert 1997: 127, fig. 46.

Monostaechas quadridens - Ansín Agís et al. 2009: 53, fig. 9. — ? Park 2010 (pro parte): 134, fig. 75a. — Watson 2011: 18, fig. 9 [non Monostaechas quadridens (McCrady, 1859)].

Monostaechas sp. - Ansín Agís et al. 2009: 54, fig. 10.

non Monostaechas fisheri - Bedot 1921b: 9. - Vannucci 1949: 252, pl. 3 figs 51-54; 1950: 90, pl. 1 fig. 6; 1951: 106, 108, 112, 114. — Von Schenck 1965: 909, figs 3d, 9 [all= Monostaechas quadridens (McCrady, 1859)].

non Monostaechas fisheri var. simplex Billard, 1913: 16, fig. 7, pl. 1 fig. 10 [= Monostaechas quadridens (McCrady, 1859)].

non Monostaechas fisheri var. simplex - Van Praët 1979: 914, fig. 7, pl. 1 fig. 10 [= Monostaechas quadridens (McCrady, 1859)].

\section{Material examined}

PACIFIC OCEAN -1 small colony with stems up to $1.5 \mathrm{~cm}$ high, some bearing simultaneously $\widehat{\delta}$ and + gonothecae; off New Caledonia, stn DW4768; $23^{\circ} 25^{\prime} \mathrm{S}, 168^{\circ} 01^{\prime} \mathrm{E}$; $180-210 \mathrm{~m}$; 27 Aug. 2016; KANACONO leg.; MNHN-IK-2015-606 5 stems up to $2 \mathrm{~cm}$ high, some with $q$ gonothecae; off New Caledonia, stn CP4688; 2229' S, 167³1' E, 278-353 m; 14 Aug. 2016; KANACONO leg.; MNHN-IK-2015-607.

\section{Additional material}

PACIFIC OCEAN - variety with shallow hydrothecae and long lateral nematothecae: 1 fertile colony, with stems up to $3 \mathrm{~cm}$ high; off New Caledonia, stn DW4725; $22^{\circ} 41^{\prime} \mathrm{S}, 167^{\circ} 05^{\prime} \mathrm{E} ; 240-256 \mathrm{~m} ; 20$ Aug. 2016; KANACONO leg.; MNHN-IK-2015-605.

\section{Comparative material}

CARIBBEAN SEA - 1 profuse, fertile colony of Monostaechas quadridens McCrady, 1859, on Sargassum sp.; France, Martinique, Anses d'Arlet; $14^{\circ} 29^{\prime}$ N, 61 $61^{\circ} 5^{\prime}$ W; 6-10 m; 29 Jan. 2012; HRG-0853. 


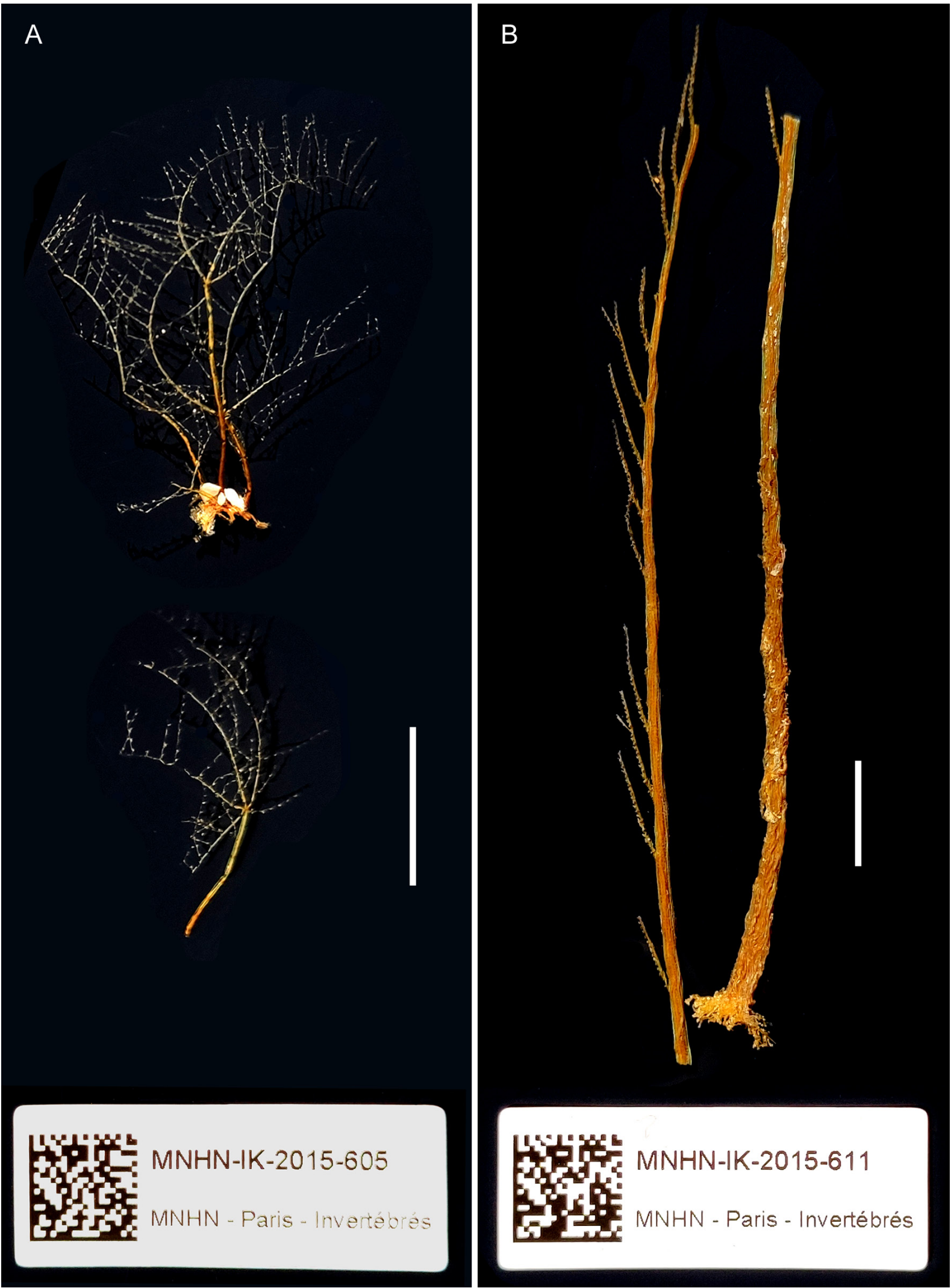

Fig. 16. A. Monostaechas fisheri Nutting, 1905, two colonies from sample MNHN-IK-2015-605. B. Thamnopteros uniserius Galea gen. et sp. nov., holotype colony, MNHN-IK-2015-611. Scale bars: $1 \mathrm{~cm}$. 
Table 8. Measurements of Monostaechas fisheri Nutting, 1905, in $\mu \mathrm{m}$.

\begin{tabular}{|c|c|c|c|c|c|}
\hline & \multicolumn{3}{|c|}{ Nominal species } & \multicolumn{2}{|c|}{ Variety } \\
\hline & $\begin{array}{l}\text { Present study, } \\
\text { MNHN- } \\
\text { IK-2015-606 } \\
\text { and -607 ( }) \\
\end{array}$ & $\begin{array}{c}\text { Ansín Agís } \\
\text { et al. (2009), } \\
\text { MUSORSTOM } \\
\text { 3, stn CP131 } \\
\end{array}$ & $\begin{array}{l}\text { Watson (2011), } \\
\text { as } \\
\text { M. quadridens }\end{array}$ & $\begin{array}{l}\text { Present } \\
\text { study, } \\
\text { MNHN- } \\
\text { IK-2015-605 }\end{array}$ & $\begin{array}{c}\text { Ansín Agís } \\
\text { et al. (2009), } \\
\text { SMIB 4, stn } \\
\text { DW55 } \\
\end{array}$ \\
\hline \multicolumn{6}{|l|}{ Stem } \\
\hline - internode length & $1080-1375$ & $1070-1750$ & $1800-2500$ & $775-1215$ & $650-830$ \\
\hline - diameter at node & $120-210$ & $100-130$ & $136-224$ & $125-195$ & $120-190$ \\
\hline - nematothecae, length & ca 115 & - & $140-160$ & - & - \\
\hline - nematothecae, diameter at rim & ca 45 & - & & - & - \\
\hline - cladial apophysis, length & $280-320$ & - & & - & - \\
\hline $\begin{array}{l}\text { - apophysis for secondary stem, } \\
\text { length }\end{array}$ & ca 125 & - & $88-120$ & - & - \\
\hline \multicolumn{6}{|l|}{ Cladia } \\
\hline - ahydrothecate internode, length & $250-500$ & $370-550$ & $240-360$ & $215-315$ & $270-350$ \\
\hline - nematotheca, length & $80-95$ & $60-80$ & - & - & $80-90$ \\
\hline - nematotheca, diameter at rim & $45-50$ & $30-40$ & - & - & $30-35$ \\
\hline - hydrothecate internode, length & $350-485$ & $460-500$ & $264-336$ & $285-370$ & $380-490$ \\
\hline - diameter at node & $80-120$ & $60-100$ & $80-96$ & - & $50-100$ \\
\hline \multicolumn{6}{|l|}{ Hydrotheca } \\
\hline - abaxial wall, length & $240-350$ & $240-270$ & $273-320$ & $155-180$ & $160-220$ \\
\hline - free adaxial wall, length & $185-225$ & $150-160$ & $128-160$ & $115-125$ & $110-140$ \\
\hline - adnate adaxial wall, length & $235-250$ & - & - & $165-185$ & - \\
\hline - diameter at rim & $275-300$ & $220-300$ & $256-280$ & $205-225$ & $210-230$ \\
\hline \multirow{2}{*}{$\begin{array}{l}\text { - mesial nematotheca, length } \\
\text { - mesial nematotheca, diameter } \\
\text { at rim }\end{array}$} & $70-90$ & $60-70$ & $88-100$ & - & ca 80 \\
\hline & $60-70$ & ca 50 & - & - & $40-50$ \\
\hline - lateral nematotheca, length & $125-150$ & $70-90$ & $100-120$ & $135-160$ & $120-160$ \\
\hline $\begin{array}{l}\text { - lateral nematotheca, diameter } \\
\text { at rim }\end{array}$ & $60-80$ & $45-60$ & - & $45-55$ & $45-50$ \\
\hline $\begin{array}{l}\text { - lateral nematotheca, apophysis } \\
\text { length }\end{array}$ & $120-140$ & - & - & $95-110$ & - \\
\hline \multirow{2}{*}{$\begin{array}{l}\text { - axillar nematotheca, length } \\
\text { - axillar nematotheca, diameter } \\
\text { at rim }\end{array}$} & $70-80$ & - & $58-80$ & - & - \\
\hline & $40-45$ & - & - & - & - \\
\hline \multicolumn{6}{|l|}{ Female gonotheca } \\
\hline - length w/o pedicel & $1170-1250$ & $490-620$ & $900-1160$ & ca 945 & - \\
\hline - maximum width & $505-650$ & $300-400$ & $520-600$ & ca 625 & - \\
\hline - diameter at aperture & $330-390$ & - & - & ca 385 & - \\
\hline - nematotheca, length & $125-140$ & - & - & - & - \\
\hline - nematotheca, diameter at rim & $70-75$ & - & - & - & - \\
\hline \multicolumn{6}{|l|}{ Male gonotheca } \\
\hline - length w/o pedicel & $435-580\left(^{*}\right)$ & $450-470$ & $360-400$ & ca 400 & - \\
\hline - maximum width & $215-255\left(^{*}\right)$ & $200-260$ & $216-224$ & ca 175 & - \\
\hline - diameter at aperture & $45-65\left(^{*}\right)$ & - & - & - & - \\
\hline - nematotheca, length & $135-145\left(^{*}\right)$ & - & - & - & - \\
\hline - nematotheca, diameter at rim & ca $65\left(^{*}\right)$ & - & - & - & - \\
\hline
\end{tabular}

Fig. 17 (opposite page).A-B. Monostaechas fisheri Nutting, 1905, stem internode with proximal portion of cladium bearing a female gonotheca, from sample MNHN-IK-2015-607 (A); male gonotheca from sample MNHN-IK-2015-606 (B). - C-I. Monostaechas fisheri Nutting, 1905, morphotype with shallower hydrothecae and longer lateral nematothecae: stem internode with proximal portion of cladium (C); lateral and axillar nematothecae from one side of a hydrotheca, seen laterally (D); axillar nematotheca occurring either singly (E) or in pairs (F), and detail of a theca seen from its adaxial side (G); male (H) and female (I) gonothecae; all from sample MNHN-IK-2015-605. — J. Monostaechas quadridens (McCrady, 1859), stem internode with proximal portion of cladium bearing a female gonotheca, from sample HRG-0853, for comparison. Scale bars: A-C, H-J $=300 \mu \mathrm{m} ; \mathrm{D}-\mathrm{G}=100 \mu \mathrm{m}$. 


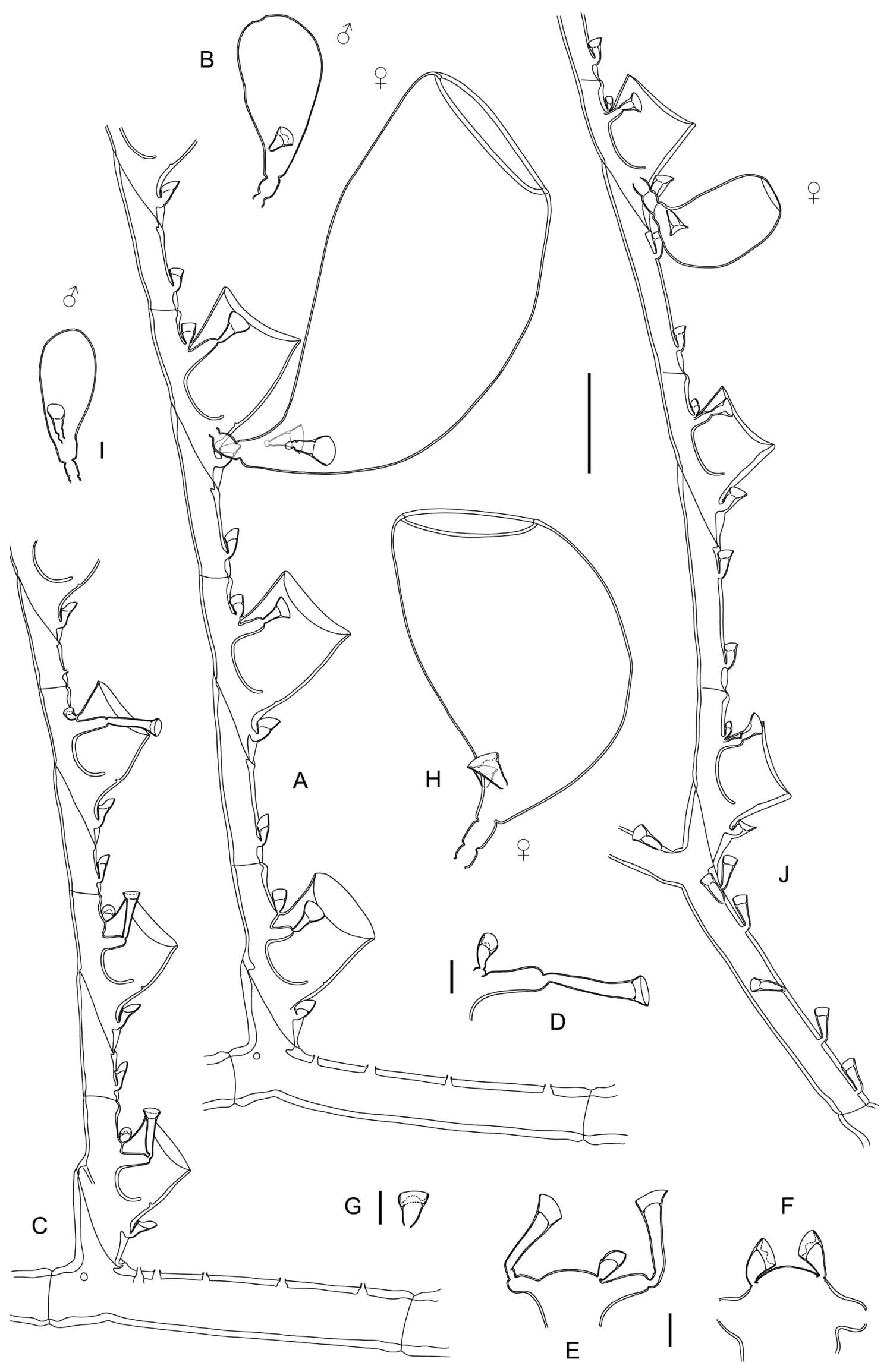




\section{Description}

Colonies upright, up to $2 \mathrm{~cm}$ high, coplanar, rigid, with thick, brown perisarc, arising from creeping, branching, slightly flattened hydrorhiza. Stem monosiphonic; proximal part straight, irregularly divided into few internodes of varied length by means of transverse nodes; distalmost nodes with two parallel, closely-set rows of frontal nematothecae; remainder of stem divided into regular internodes by transverse nodes; each internode moderately long, straight, bearing one or two lateral apophyses and 4-6 frontal nematothecae in two closely-set rows; apophyses subterminal on internodes; when two of these are present on same internode, either opposite or subopposite; two types of apophyses: first type very short, ending in straight node and bearing secondary stem, and second type comparatively longer, ending in oblique node and bearing cladium; first regular thecate stem internode with either pair of dissimilar apophyses, one bearing secondary stem, the other a cladium, or with pair of apophyses supporting two secondary stem; in the latter case, following internode may bear two dissimilar apophyses; remainder of stem internodes with single apophyses supporting cladia only, distal part of stem assuming scorpioid shape, typical of genus. Secondary stems, like main stem, divided into regular internodes, each bearing nematothecae and upwardly-directed apophysis supporting cladium; consequently, all their cladia point upwards with respect to colony, and their hydrothecae all facing towards main stem. All cladia borne directly on main stem have their hydrothecae facing downwards in proximal part of colony and, as stem curves away in scorpioid manner, hydrothecal apertures of more distal cladia increasingly facing outwards or even upwards, depending of length of distal part of stem and number of cladia it bears. Cladia up to $8 \mathrm{~mm}$ long, heteromerously divided into hydrothecate and ahydrothecate internodes; up to 10 hydrothecate internodes per cladium, relatively short, each with proximal node oblique and distal node transverse, bearing hydrotheca in middle and its complement of nematothecae: one mesial, a pair of laterals, as well as axillar one on one side of hydrotheca; hydrotheca deep, tubular, half adnate, free adaxial wall and abaxial wall nearly straight, aperture circular, rim smooth; all nematothecae movable and bithalamic; laterals conical, borne on conspicuous apophyses, whole set reaching hydrothecal rim; upper chamber of lateral nematothecae lowered on adaxial side, and there with sinusoid margin. Cladial ahydrothecate internodes of varied length, with proximal node straight and distal node oblique, each bearing frontal nematotheca proximally. Stems either mono- or dioecious; gonothecae sexually dimorphic, borne exclusively on cladia by means of 2-segmented pedicel, given off laterally between base of hydrotheca and its mesial nematotheca; female gonothecae large, piriform, slightly flattened laterally, distally truncate and there with broad, thickened, ovoid aperture, proximally with 2-3 nematothecae; male gonothecae, comparatively smaller, ovoid, circular in transverse section, distally with small, rounded aperture, proximally with a nematotheca.

\section{Remarks}

The illustrations and measurements provided by Ansín Agís et al. (2009) leave little doubt that their material is conspecific with that dealt with herein. Although they identified it as M. quadridens (McCrady, 1859), it could be demonstrated that they are specifically distinct. Indeed, Caribbean specimens (Galea 2010), corresponding strictly to earlier descriptions of McCrady's species, are more delicate in appearance and build exclusively scorpioid sympodia, while the present material is composed of comparatively stronger colonies with distinct, upright, straight main stems (Fig. 17J).

Monostaechas fisheri is still a poorly-known, seldomly-recorded species. Speculations on its affinities with M. quadridens often provided inconclusive or cautious opinions (e.g., Stechow 1925; Vervoort 1968; Migotto 1996; Schuchert 1997), although some authors pleaded for a definitive inclusion in its synonymy (e.g., Leloup 1937; Watson 2011).

Schuchert (1997) reexamined the type of M. fisheri and provided a comprehensive description and illustrations of it. It is mainly characterized by the presence of a definite, straight main stem, a peculiar mode of branching, with secondary stems arising singly or forming opposite pairs with a cladium (see 
also Nutting 1905: pl. 5 fig. 3). No such branching pattern is known to occur in M. quadridens, although the existence of dichotomously-branched colonies (e.g., Allman 1877: pl. 22 figs 1-5, as M. dichotoma; Nutting 1900: pl. 13 fig. 1; Vervoort 1968; Hirohito 1974: fig. 16d; Calder 1983; Hirohito 1995: fig. 84b) is not uncommon, while the occurrence of aberrant secondary stems (Hirohito 1995: fig. 84a) is a rare, peculiar condition.

Unlike the present material from New Caledonia, the cladial ahydrothecate internodes of the type material of $M$. fisheri possess two nematothecae instead of only one, although no other differences could be noted between them. It is thus assumed that the present material is, with little doubt, conspecific with M. fisheri. Supporting this hypothesis, Watson (2011, as M. quadridens) noted the presence of 1-2 nematothecae in her specimens, with distinct stems that could probably be assignable as well to Nutting's (1905) hydroid. Their color in life was "dark purplish grey", thus different from the paleyellow colonies of M. quadridens from the Caribbean collected by Galea (2010). Although Watson argued that her Australian material was indistinguishable from a colony of M. quadridens from Sapelo Island, GA, USA, no information, notably on the condition of the stem, was provided to support her statement.

Only male gonothecae, bearing a single basal nematotheca, have been documented in M. fisheri (Schuchert 1997). The present material also possesses female gonothecae, of a much larger size compared to those of $M$. quadridens, and bearing 2-3 basal nematothecae, further supporting the specific separation between these species. Similar gonothecae were reported upon by Watson (2011: fig. 9e).

Specimens in material MNHN-IK-2015-605 show a more complex branching pattern of the main stem, with an increasing number of ramifications per site, and the formation of up to third order stems. Some examples of branching are illustrated in Fig. 18. This appears to be a variety of the nominal species, distinguished by its proportionally smaller and shallower hydrothecae and longest (trumpet-shaped) lateral nematothecae, the other morphological characters, including the shape and size of gonothecae of both sexes, being similar to those of the nominal species.
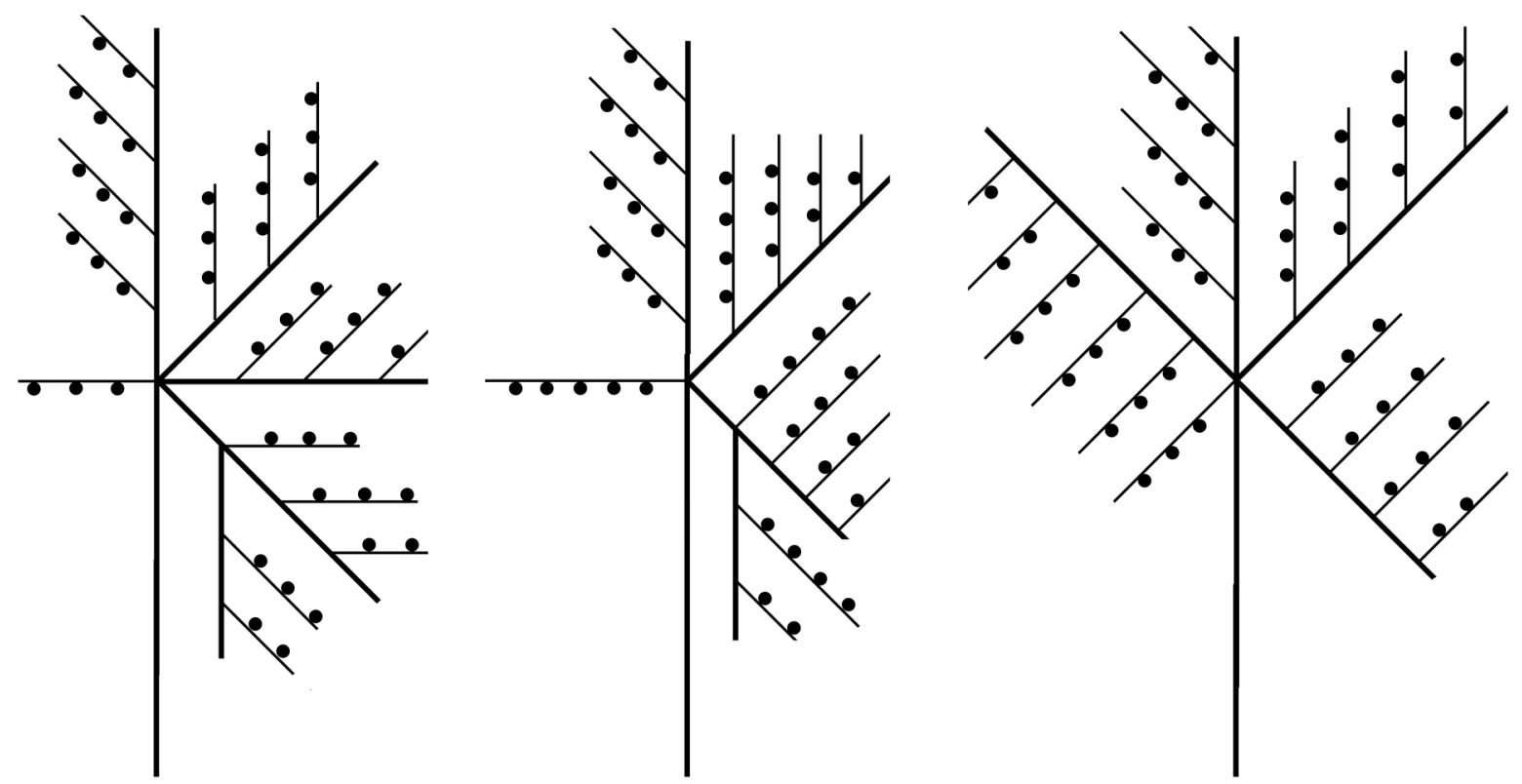

Fig. 18. Monostaechas fisheri Nutting, 1905, morphotype with shallower hydrothecae and longer lateral nematothecae: patterns of branching. Slender lines represent cladia, thicker lines show primary, secondary or tertiary stems; dots correspond to the hydrothecae. 
A series of records attributed to $M$. fisheri are, most probably, based on misidentifications. Indeed, the Cape Verde material studied by Bedot (1921b) is said to exhibit all characters of $M$. fisheri var. simplex Billard, 1913, which is now recognized as the simplest mode of colony growth met with in McCrady's hydroid (e.g., Schuchert 1997).

Additionally, Vannucci's $(1949,1950)$ material reportedly comprised both simple and ramified stems, although their mode of branching was not described in detail. On the account of their geographical occurrence and the size of their female gonothecae with respect to the hydrothecae (Vannucci 1950: pl. 1 fig. 6), it is believed that she actually had specimens of M. quadridens. Migotto (1996) agrees that "Vannucci's description (1949) of M. fisheri [...] clearly conforms with the current conception of M. quadridens".

The colony illustrated by Park (2010: fig. 75a, as M. quadridens) shows a peculiar branching pattern, approaching the condition met with in the present species, and both could be conspecific. However, her description fits the classical concept of $M$. quadridens, as well as the size of the illustrated gonothecae (Park 2010: fig. 75b, d) do, but, since many colonies were available, it is conceivable that some belonged to one species, while some others to the second one.

\section{Distribution}

Hawai'i (Nutting 1905), ? Korea (Park 2010), Australia (Watson 2011), New Caledonia (Ansín Agís et al. 2009; present study), Chesterfield Islands and Philippines (Ansín Agís et al. 2009).

Genus Polyplumaria G.O. Sars, 1874

Polyplumaria cornuta (Bale, 1884)

Fig. 19

Plumularia cornuta Bale, 1884: 132, pl. 11 figs 1-2.

Polyplumaria cornuta var. longispina Billard, 1913: 56, fig. 47.

Polyplumaria cornuta - Bale 1887: 95. — Billard 1913: 53, fig. 46, pl. 3. fig. 33, pl. 4 figs 35-36. Bedot 1921a: 15. — Briggs \& Gardner 1931: 191. — Watson 2000: 56, fig. 44. — Schuchert 2003: 213, fig. 62. - Ansín Agís et al. 2014: 831, figs 27-28.

\section{Material examined}

PACIFIC OCEAN $11 \mathrm{ca} 60 \mathrm{~cm}$ high, sterile colony; off New Caledonia, stn CP4655; $22^{\circ} 31^{\prime} \mathrm{S}, 167^{\circ} 04^{\prime} \mathrm{E}$; 79-79 m; 10 Aug. 2016; KANACONO leg.; MNHN-IK-2015-576.

\section{Distribution}

Indonesia (Billard 1913; Schuchert 2003), Australia (Bale 1884; Briggs \& Gardner 1931; Watson 2000), New Caledonia (Ansín Agís et al. 2014; present study).

Genus Thamnopteros Galea gen. nov. urn:lsid:zoobank.org:act:687DE3EB-696E-49DC-8E12-22C1D62020D2

\section{Diagnosis}

Colonies tall, branched or unbranched; stems and, when present, side branches stiff, thick and strongly fascicled, giving rise regularly or irregularly to hydrocladia-bearing branchlets from individual deeper tubes; branchlets monosiphonic, Halopteris-like, with basal prosegment, followed by a regular succession of modules (separated or not by nodes), each carrying a hydrotheca, its associated nematothecae, and a 


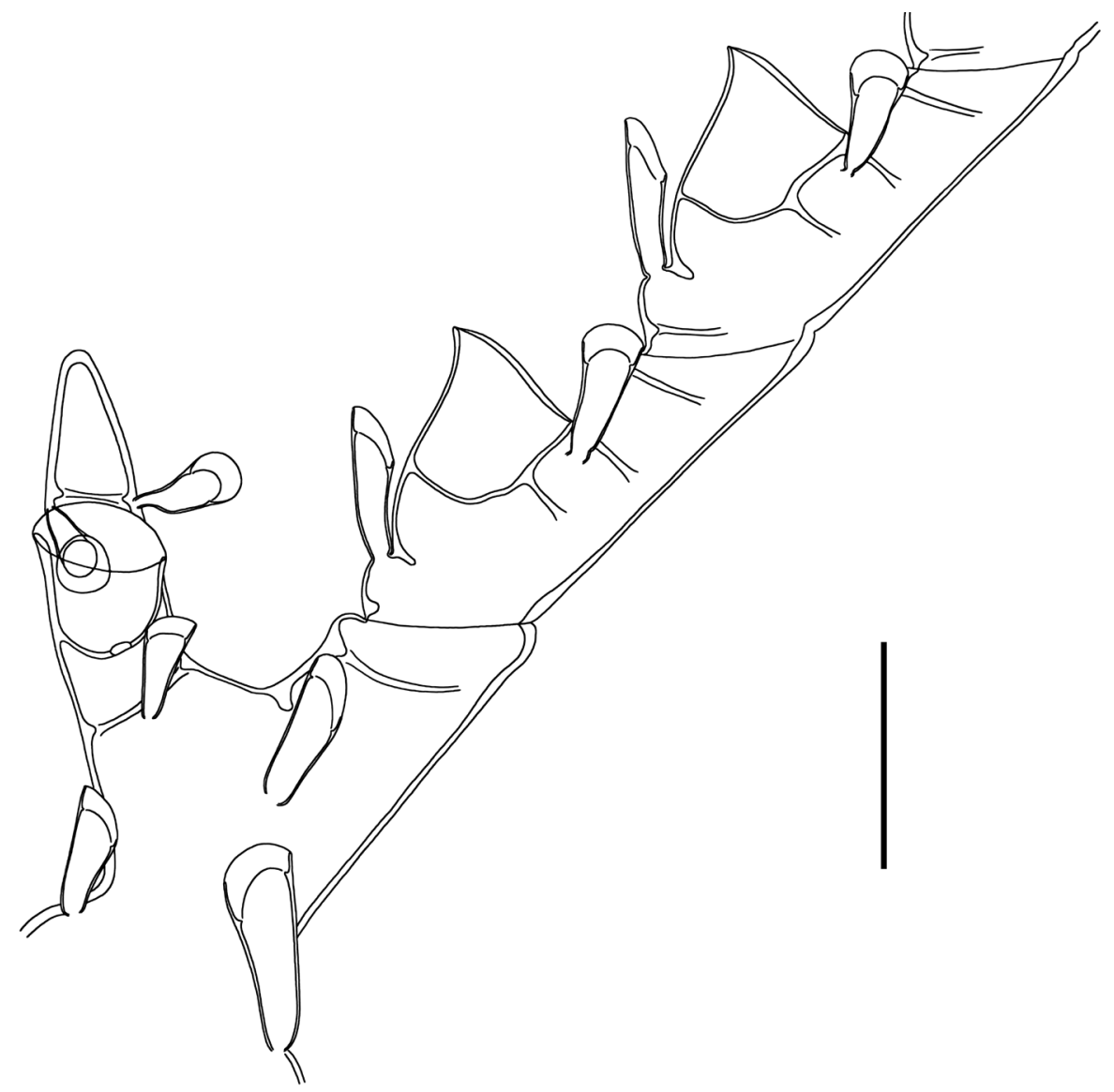

Fig. 19. Polyplumaria cornuta (Bale, 1884), cladial apophysis and proximal portion of cladium, from sample MNHN-IK-2015-576. Scale bar: $200 \mu \mathrm{m}$.

cladial apophysis laterally; cladia alternate, except for $1^{\text {st }}$ and/or $2^{\text {nd }}$ cormidium of each branchlet, where they can be opposite; cladia with short, proximal, athecate internode, followed by a succession of modules (either divided or undivided by nodes) composed of a hydrotheca and its associated nematothecae. Lateral nematothecae of varied length, occasionally exceedingly long, members of a pair usually of different lengths. Gonothecae provided with several basal, bithalamic nematothecae.

\section{Type species}

Heteroplon valdiviae Stechow, 1923, designated herein (see below).

\section{Etymology}

From Ancient Greek ' $\theta \dot{\alpha} \mu v o \varsigma$ ', meaning 'bush', and ' $\pi \tau \varepsilon \rho o ́ v$ ', meaning 'wing' or 'feather', to illustrate the appearance of the colonies of hydroids assignable to the present genus. The genus is masculine.

\section{Remarks}

The species under discussion herein (see below) shows obvious similarities with a hydroid described by Stechow (1923c) under the basionym Heteroplon valdiviae. The latter forms large, ramified, fascicled colonies, giving rise irregularly, from the deeper tubes, to monosiphonic, Halopteris-like branchlets facing in all directions around the stem and/or its branches. The axes of branchlets are provided proximally with a prosegment, and occasionally with as many as four (Millard 1962); the prosegment bears a hydrotheca, its complement of nematothecae, and a pair of opposite cladial apophyses; the 
remainder of axis comprises a succession of hydrothecate internodes, each bearing a cladial apophysis lateral to a hydrotheca (proximalmost hydrotheca occasionally has a pair of opposite cladial apophyses); the apophyses are arranged alternately along the axis. With the exception of a short, proximal, athecate internode, followed by a nematothecate internode, the remainder of cladium is composed of a succession of thecate internodes separated by oblique nodes. Each hydrotheca, on both axes and cladia, is surrounded by 5 nematothecae: a mesial (well below its basis), a pair of laterals (of varied length and borne on short, conical apophyses), and a pair of axillar (Millard 1975).

Stechow's (1923) species was sometimes assigned to Halopteris (e.g., Millard 1957, 1962) and sometimes to Corhiza (Millard 1975; Schuchert 1997). Millard (1975) argued that a genus allocation to Corhiza was more opportune, for the "appearance of the colony is very similar to C. scotiae, differing from it in the fact that the diverging tubes of the stem form sub-branches instead of hydrocladia". The diagnosis of Corhiza was modified accordingly, so as to include species with "branches [...] bearing cauline hydrothecae and pinnately arranged hydrocladia", as well (Millard 1975: 334).

However, Millard's (1975) opinion that unites into a single genus species whose fascicled stems and, if present, branches give rise to either Antennella-like hydrocladia or Halopteris-like branchlets, is not shared here. If this principle is applied to the genera Antennella and Halopteris, they must also be regarded as congeneric, although increasing evidence demonstrates that both are polyphyletic (Moura et al. 2018).

The new genus comprises presently two species, Thamnopteros valdiviae (Stechow, 1923), its type species, and T. uniserius Galea gen. et sp. nov., described below.

Thamnopteros uniserius Galea gen. et sp. nov. urn:1sid:zoobank.org:act:BFE82D80-8626-4B67-B66F-24C230D91882

Figs 16B, 20; Table 9

\section{Diagnosis}

General description as for the genus. Branches with basal prosegment, followed by a regular succession of modules comprising hydro- and nematothecae, each hydrotheca accompanied by a lateral, cladial apophysis; apophyses alternate; hydrothecae truncated cones, with 5 associated nematothecae and $0-1$ nematothecae above; cladia with short, proximal, quadrangular segment, followed by an succession of modules, each bearing a tubular hydrotheca and its complement of 5 nematothecae; no nematothecae between successive cladial hydrothecae. All hydrothecae ca $1 / 3^{1 / \mathrm{d}}$ adnate, with one mesial, a pair of lateral (often of varied length), and two axillar nematothecae; all nematothecae bithalamic. Gonothecae borne on cladia; piriform, with 3 basal, elongated nematothecae, distally truncate, rim rounded, thickened.

\section{Etymology}

From Latin ' 'ūnus, $-a,-u m$ ', meaning 'one', and 'sěriēes', meaning 'row', to emphasize the unilateral arrangement of branches along the main stem.

\section{Material examined}

\section{Holotype}

PACIFIC OCEAN - 1 sterile colony broken into two pieces, basal part ca $8.5 \mathrm{~cm}$ high, distal part ca $8.7 \mathrm{~cm}$ high; off New Caledonia, stn CP4754; 2322' S, 16754' E; 1009-1019 m; 25 Aug. 2016; KANACONO leg.; MNHN-IK-2015-611.

\section{Description}

Colony erect, originally ca $17.2 \mathrm{~cm}$ high, now broken into two, almost equal parts, of rigid appearance, with brown perisarc, arising from rhizoid stolon. Stem unbranched, $2.5 \mathrm{~mm}$ thick at base, strongly 
Table 9. Measurements of Thamnopteros uniserius Galea gen. et sp. nov., in $\mu \mathrm{m}$.

\begin{tabular}{lc}
\hline & MNHN-IK-2015-611 \\
\hline Axis of Halopteris-like branch & $1100-1255$ \\
- prosegment, length & $190-235$ \\
- diameter & $485-510$ \\
- distance between successive hydrothecae & \\
Hydrotheca (branch) & $100-115$ \\
- free adaxial wall, length & $155-170$ \\
- adnate adaxial wall, length & $160-190$ \\
- abaxial wall, length & $165-175$ \\
- diameter at rim & \\
- apophyses for lateral nematothecae, length & $115-405$ \\
- lateral nematothecae, length & $70-75$ \\
- lateral nematothecae, diameter at rim & \\
Cladia & $145-165$ \\
- diameter & $535-555$ \\
- distance between successive hydrothecae & \\
Hydrotheca (cladium) & $85-95$ \\
- free adaxial wall, length & $205-215$ \\
- adnate adaxial wall, length & $175-215$ \\
- abaxial wall, length & $180-205$ \\
- diameter at rim & $155-435$ \\
- lateral nematothecae, length & ca 75 \\
- lateral nematothecae, diameter at rim & $100-110$ \\
- mesial nematotheca, length & $70-80$ \\
- mesial nematotheca, diameter at rim & $75-85$ \\
- axillar nematotheca, length & $40-45$ \\
- axillar nematotheca, diameter at rim & \\
Gonotheca & ca 1055 \\
- length w/o pedicel & ca 450 \\
- maximum width & ca 420 \\
- diameter at aperture & $160-225$ \\
- nematothecae, length & $70-75$ \\
- nematothecae, diameter at rim & \\
& \\
\hline & \\
& \\
& \\
& \\
&
\end{tabular}

fascicled, displaying superficially a number of tortuous tubes that seem to wrap an internal beam of straight counterparts, as shown by a couple of small, less organized areas on surface that reveal a possible sheath-like general structure. Tubes on stem surface provided with two longitudinal, laterally-set rows of opposite nematothecae along their length. Upper half of stem gives rise unilaterally, at regular intervals, to monosiphonic, Halopteris-like branches arising from internal beam of component tubes; before each of these tubes becomes free from the fascicled stem, the distal ends of their fused parts become apparent at the surface of the stem for a varied length, displaying on their exposed side two closely-set rows of alternate nematothecae; a short distance (no longer than $1 \mathrm{~cm}$ ) after diverging from the stem, each tube acquires suddenly a well-organized structure: a basal prosegment is followed by a regular succession of hydrothecae (with their associated nematothecae) and lateral apophyses supporting the cladia. Except for the prosegment, that is delimited at both ends by deeply-incised, very oblique nodes, the remainder of tube is unsegmented. The prosegment bears a hydrotheca devoid of cladial apophyses, its 5 associated nematothecae ( 1 mesial, far below the base, 1 pair of laterals and 1 pair of axillar), as well as up to 4 nematothecae in two rows above the hydrotheca. Remainder of tube with modules 
composed of a hydrotheca and its 5 associated nematothecae (as above), an apophysis lateral to it (except for proximalmost hydrotheca that has a pair), as well as $0-1$ nematothecae above the hydrotheca. Hydrothecae shifted alternately left and right; truncated cones in shape (broader at base than at aperture), half free from the 'internode'; abaxial wall straight, free adaxial wall slightly concave, both with quite

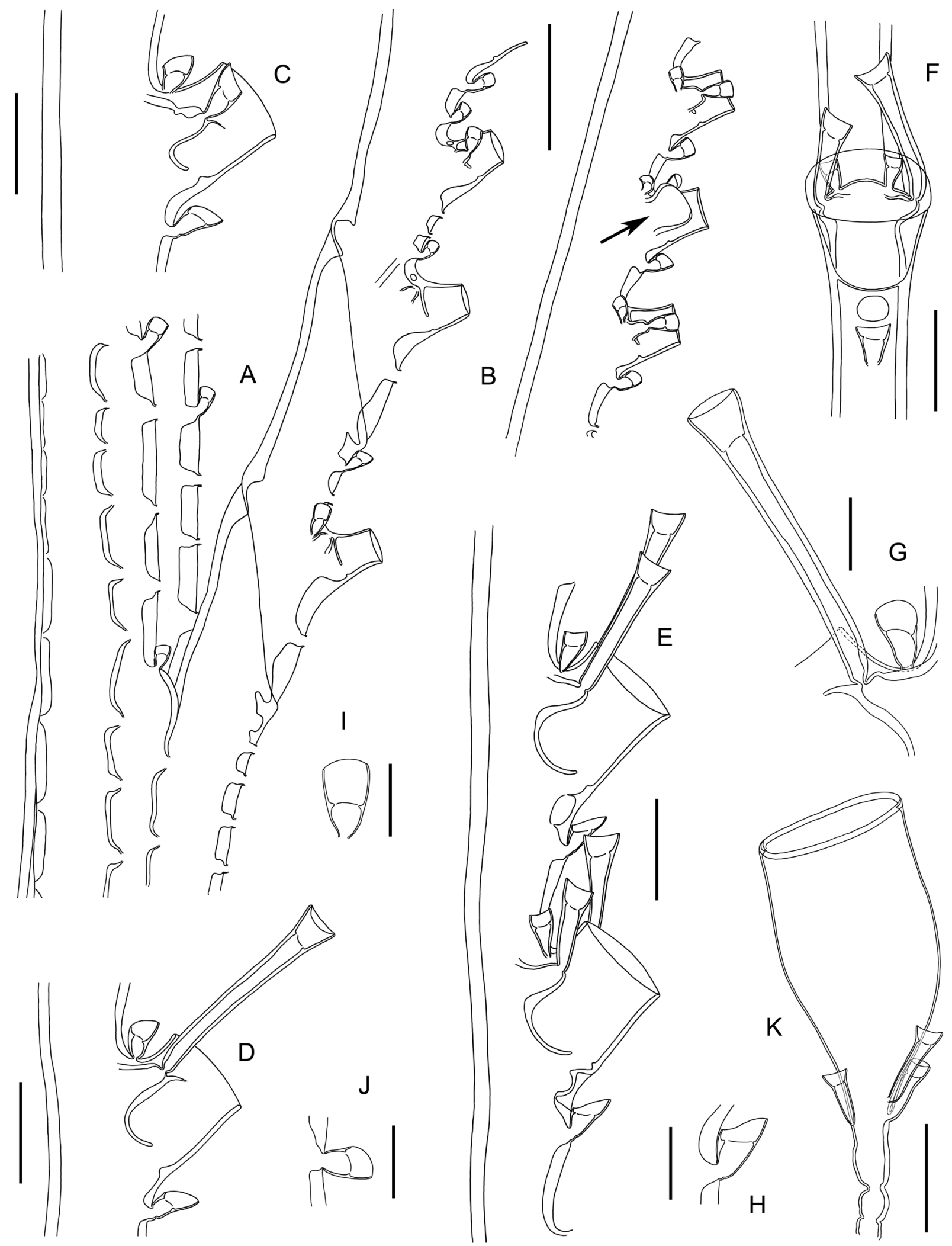


thick perisarc; mesial nematotheca movable, with wall of upper chamber lowered on adaxial side; lateral nematothecae borne on fairly-developed apophyses fused distally to the hydrothecal wall, as illustrated by a peg-like projection of perisarc, running frontally for a short distance over the hydrothecal wall; lateral nematothecae of varied length, generally short on proximalmost cormidia, and exceedingly long distally; basal chamber very tall, upper chamber shallow, with circular, entire rim; axillar nematothecae bithalamic, wall of upper chamber slightly lowered on adaxial side. Cladial apophyses short, athecate, shifted laterally so that the two rows of hydrocladia they carry form an acute angle between them. Hydrocladia up to $4 \mathrm{~mm}$ long, unsegmented, except for a short, proximal, quadrangular segment; cladia comprising up to 10 modules, each with one hydrotheca and its 5 associated nematothecae (as above); there are no additional nematothecae between 2 successive hydrothecae; the lateral nematothecae are generally exceedingly tall and often of unequal length. Gonothecae, likely female, borne on cladia, each inserted laterally between the base of a hydrotheca and its mesial nematotheca through a short apophysis; pedicel of one short, quadrangular piece; gonotheca piriform, with 2-3 proximal, quite long nematothecae, distally truncate, with distinctly thickened, circular rim, apparently without lid.

\section{Remarks}

The new species differs from Thamnopteros valdiviae (Stechow, 1923) in having: 1) all Halopterislike branchlets given off unilaterally from the stem, instead of pointing in all directions around it; 2) undivided axes and cladia; 3) cladia missing an intervening nematothecate internode between the proximalmost, quadrangular segment and the remainder of cladium; 4) hydrothecae with an even rim, not sinuated laterally; 5) bithalamic instead of scale-shaped axillar nematothecae.

\section{Distribution}

Only known from its type locality, off New Caledonia (present study).

\section{Genetic results}

The newly sequenced specimens were used to build updated phylogenetic hypotheses for the families Aglaopheniidae, Plumulariidae, and Halopterididae, based on the 16S rRNA region (Figs 21-23). Overall, all families showed a pervasive polyphyly of genera, as previously demonstrated by other studies using the same DNA region (e.g., Galea et al. 2018; Moura et al. 2018), but non-monophyly was also commonly observed using multi-locus approaches (Maronna et al. 2016). Therefore, a thorough integrative morpho-molecular revision is needed to better define the generic and specific boundaries in these plumularioid families.

In the Aglaopheniidae tree (Fig. 21), the newly produced sequences represent the first genetic data for the analysed species, except for Gymnangium expansum (Jäderholm, 1903), which clusters with a conspecific sequence. Sequences of the recently-described Cladocarpus pennatus Galea, 2020 cluster in a monophyletic group, divergent from all other Cladocarpus sequences, and the same happens for

Fig. 20 (opposite page). Thamnopteros uniserius Galea gen. et sp. nov., portion of fascicled stem giving rise laterally to a Halopteris-like branch, of which only the proximalmost part, showing the prosegment, is depicted (A); more distal portion of another branch, note slight change in the hydrothecal shape (the arrow indicates a cladial apophysis) (B); two cauline hydrothecae seen laterally, to show variation in the length of the lateral nematothecae (C-D); cladial hydrothecae seen laterally (E) and frontally (F), note differences in the size of the lateral nematothecae belonging to each pair; detail of the hydrothecal axil $(\mathrm{G})$; nematothecae: mesial $(\mathrm{H})$, of the component tubes of the fascicled stem (I), and from above the cauline hydrothecae $(\mathrm{J})$; gonotheca $(\mathrm{K})$; all from sample MNHN-IK-2015-611. Scale bars: A-B = $500 \mu \mathrm{m} ; \mathrm{C}-\mathrm{F}=200 \mu \mathrm{m} ; \mathrm{G}-\mathrm{J}=100 \mu \mathrm{m} ; \mathrm{K}=300 \mu \mathrm{m}$. 


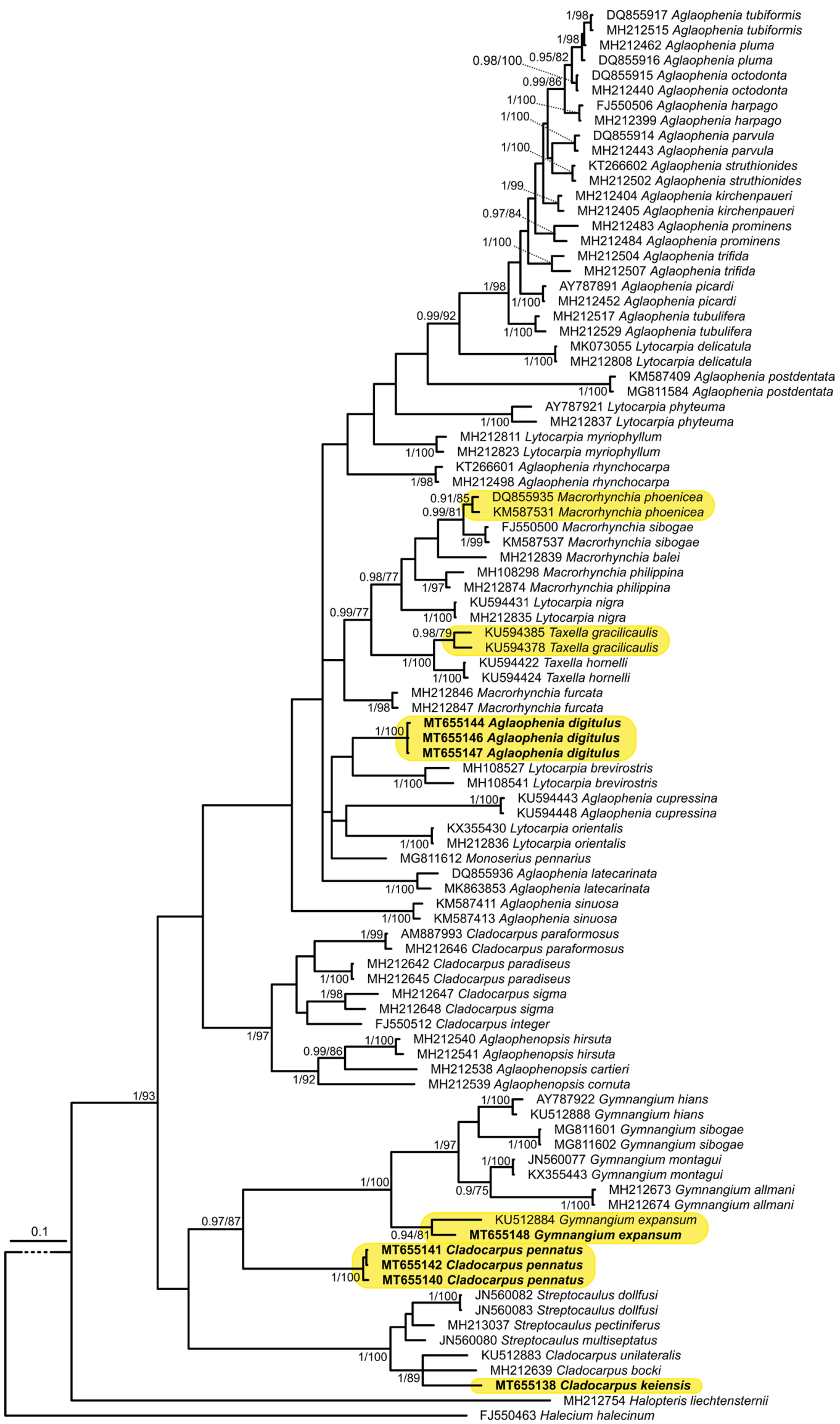




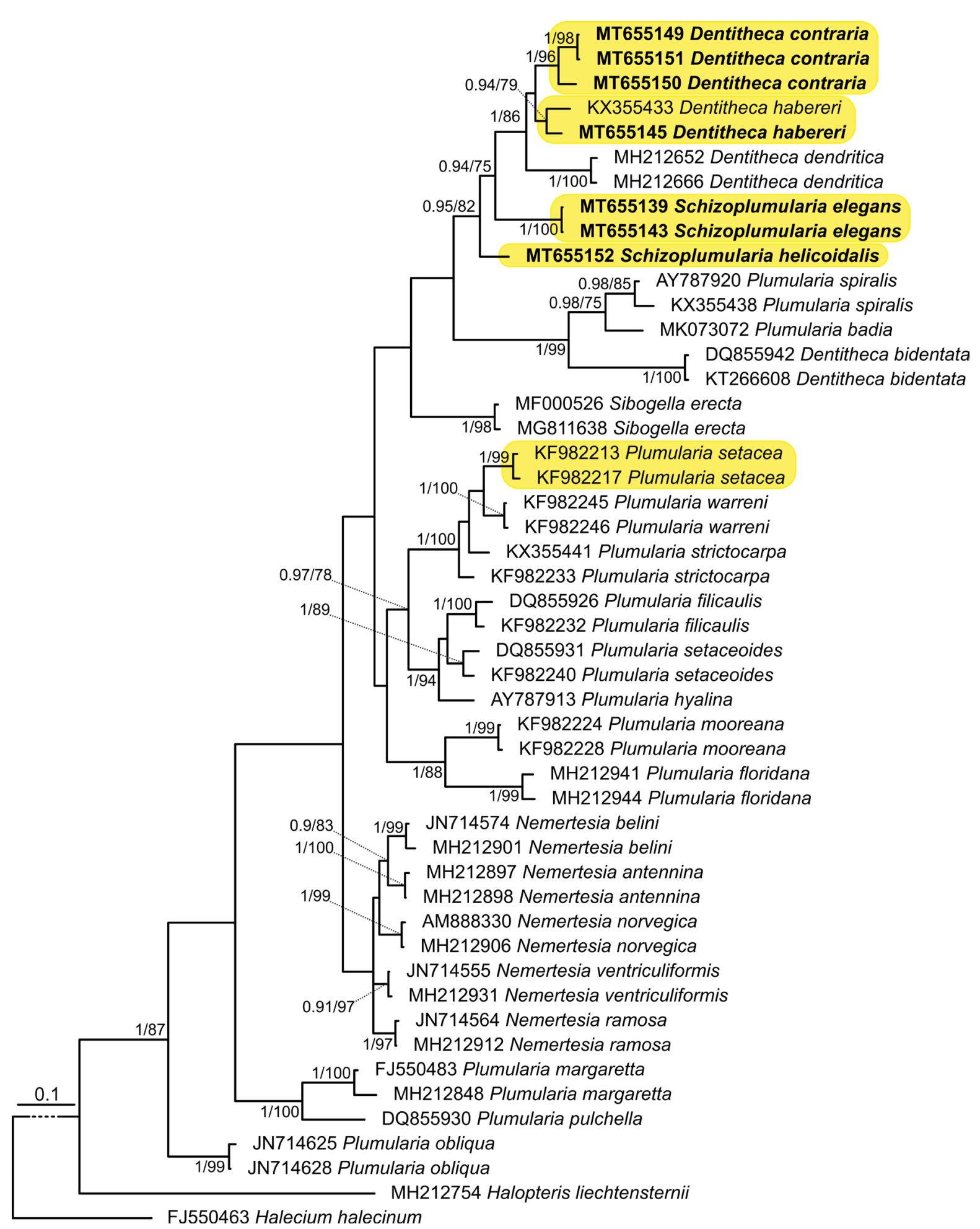

Fig. 22. Phylogenetic hypothesis for the Plumulariidae McCrady, 1859. Species discussed in this study are highlighted in yellow. Newly produced sequences are in bold. Numbers at nodes represent BPP and $\mathrm{BS}$, respectively, and are shown only when both $\mathrm{BPP} \geq 0.9$ and $\mathrm{BS} \geq 75$.

Fig. 21 (opposite page). Phylogenetic hypothesis for the Aglaopheniidae Marktanner-Turneretscher, 1890. Species discussed in this study are highlighted in yellow. Newly produced sequences are in bold. Numbers at nodes represent Bayesian posterior probabilities (BPP) and maximum likelihood bootstrap supports (BS), respectively, and are shown only when both $\mathrm{BPP} \geq 0.9$ and $\mathrm{BS} \geq 75$. 
Aglaophenia digitulus Vervoort \& Watson, 2003, highlighting the peculiar nature of these species and their possible belonging to other genera. Finally, Cladocarpus keiensis Schuchert, 2003 clusters with C. unilateralis Schuchert, 2005 and C. bocki Jäderholm, 1919, and all together form a fully-supported monophyletic group with 3 species of Streptocaulus, suggesting that the scope of these genera is in need of a revision.

Regarding the Plumulariidae (Fig. 22), the newly-produced sequence of Dentitheca habereri (Stechow, 1909 ) clusters with a conspecific sequence from Japan, and this species is closely-related to $D$. contraria comb. nov. (confirming the assumption based on morphological grounds alone, see above), even though with low nodal support, and with D. dendritica (Nutting, 1900). Sequences of Schizoplumularia are sister to the group composed of the species of Dentitheca mentioned above, and the two species, Schizoplumularia elegans Ansín Agís et al., 2016 and S. helicoidalis sp. nov. do not form a monophyletic group in our phylogenetic hypothesis. Sequences of Schizoplumularia spp. and D. contraria comb. nov. were also produced for the first time with this work.

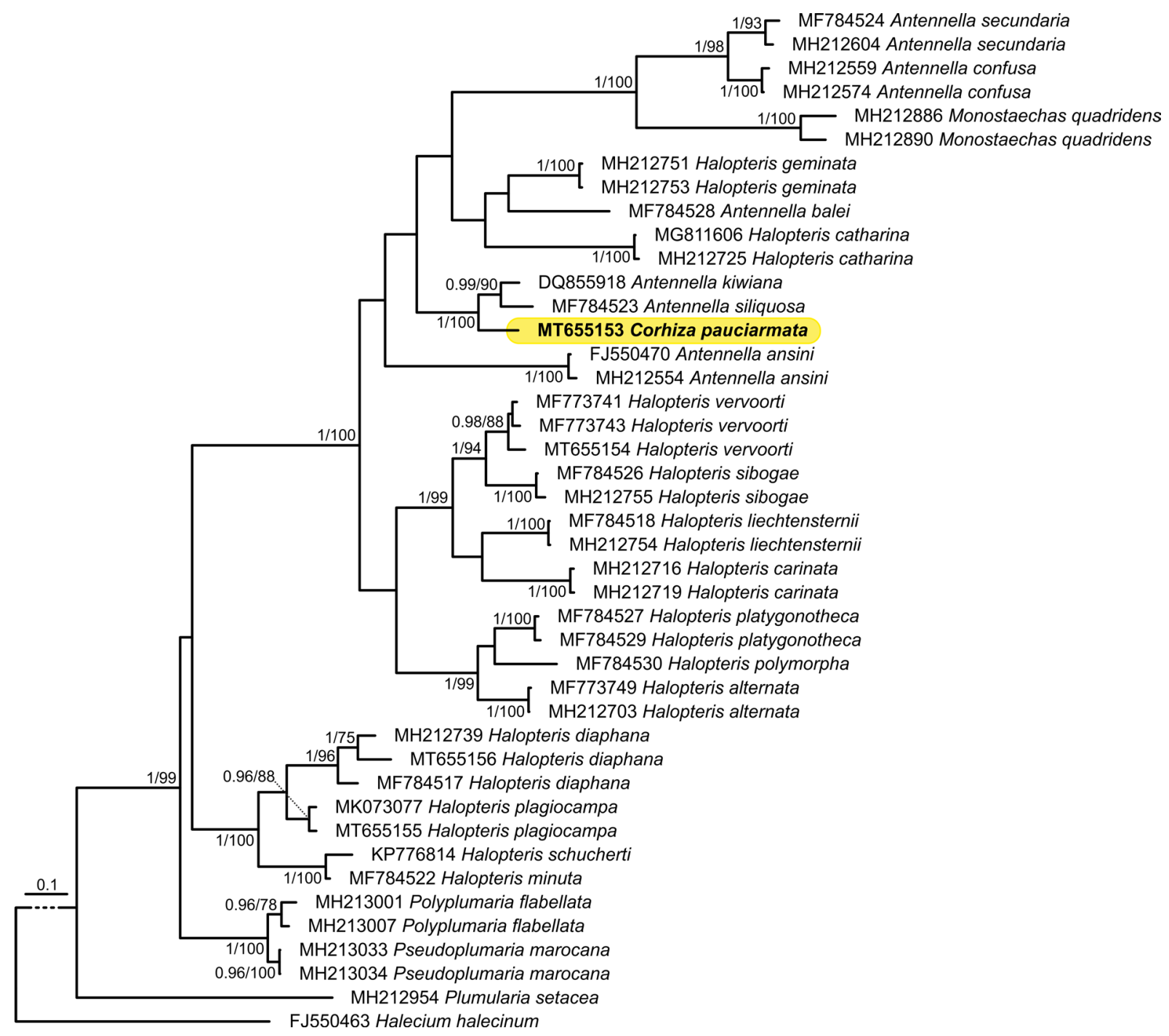

Fig. 23. Phylogenetic hypothesis for the Halopterididae Millard, 1962. The species discussed in this study is highlighted in yellow, and the newly-produced sequence is in bold. Numbers at nodes represent $\mathrm{BPP}$ and BS, respectively, and are shown only when both $\mathrm{BPP} \geq 0.9$ and $\mathrm{BS} \geq 75$. 
Finally, the sequence of Corhiza pauciarmanta Ansín Agis et al., 2009, in the Halopterididae tree (Fig. 23), forms a fully supported group with Antennella kiwiana Schuchert, 1997 and A. siliquosa (Hincks, 1877), and represents the first genetic data obtained for both genus and species.

\section{Discussion}

The present study, dealing with the plumularioid hydroids gathered by KANACONO and KANADEEP expeditions, supplements earlier reports on the hydroid fauna from off New Caledonia (Ansín Agís et al. 2009, 2014, 2016), and adds a number of new records. Among these, two new genera and four new species are described, viz, Actinopluma mirifica Galea gen. et sp. nov., Schizoplumularia helicoidalis sp. nov., Corhiza patula Galea sp. nov. and Thamnopteros uniserius Galea gen. et sp. nov. Additionally, so far unrecorded fertile specimens of Plumularia contraria Ansín Agís et al., 2014 and complete colonies assignable to Antennella megatheca Ansín Agís et al., 2009, were found, allowing their generic transfer to Dentitheca Stechow, 1919 and Corhiza Millard, 1962, respectively. Monostaechas fisheri Nutting, 1905 , a species of so far questionable validity, is rediscovered and redescribed, and its distinguishing characters from M. quadridens (McCrady, 1859), a species to the synonymy of which it has often been assigned, are underlined, to support their specific separation.

\section{Acknowledgements}

Specimens were obtained during expeditions organized by the MNHN and Pro-Natura International as part of the Our Planet Reviewed program, and by the MNHN and the Institut de Recherche pour le Développement as part of the Tropical Deep-Sea Benthos Program. The collectors are grateful to the crew of R/V Alis and to the cruise leaders Nicolas Puillandre (KANACONO), as well as Sarah Samadi and Stephane Houdez (KANADEEP). All expeditions operated under the regulations in force and satisfy the conditions set by the Nagoya Protocol for the access to genetic resources. Dr Dale R. Calder (Royal Ontario Museum, BC, Canada) is thanked sincerely for sharing his view on several taxonomical and nomenclatural matters. Dr Cristina G. Di Camillo (Università Politecnica delle Marche, Ancona, Italy) kindly provided a sample and data used in this study.

\section{References}

Allman G.J. 1877. Report on the Hydroida collected during the exploration of the Gulf Stream by L.F. de Pourtalès, Assistant United States Coast Survey. Memoirs of the Museum of Comparative Zoölogy at Harvard College 5 (2): 1-66. https://doi.org/10.5962/bhl.title.10420

Allman G.J. 1883. Report on the Hydroida dredged by H.M.S. Challenger during the years 1873-76. Part I. - Plumularidae. Report on the Scientific Results of the Voyage of H.M.S. Challenger during the years 1873-76, Zoology 7 (20): 1-55. https://doi.org/10.5962/bhl.title.11299

Ansín Agís J., Vervoort W. \& Ramil F. 2009. Hydroids of the family Halopterididae (Cnidaria, Hydrozoa) collected in the western Pacific by various French expeditions. Zoosystema 31 (1): 33-61. https://doi.org/10.5252/z2009n1a3

Ansín Agís J., Vervoort W. \& Ramil F. 2014. Hydroids of the families Kirchenpaueriidae Stechow, 1921 and Plumulariidae McCrady, 1859 (Cnidaria, Hydrozoa) collected in the western Pacific Ocean by various French expeditions. Zoosystema 36 (4): 789-840. https://doi.org/10.5252/z2014n4a6

Ansín Agís J., Ramil F. \& Calder D.R. 2016. One new genus and three new species of plumulariid hydroids (Cnidaria, Hydrozoa, Plumulariidae) from the western Pacific Ocean, with a re-examination of Plumularia insignis Allman, 1883 and related taxa. Zootaxa 4169 (1): 57-86.

https://doi.org/10.11646/zootaxa.4169.1.3 
Bale W.M. 1884. Catalogue of the Australian Hydroid Zoophytes. Australian Museum, Sydney. https://doi.org/10.1080/00222938509459871

Bale W.M. 1887. The genera of the Plumulariidae, with observations on various Australian hydroids. Transactions and Proceedings of the Royal Society of Victoria 23: 73-110.

Bale W.M. 1914. Report on the Hydroida collected in the Great Australian Bight and other localities. Fisheries. Zoological (and Biological) Results of the Fishing Experiments carried out by F.I.S. "Endeavour", 1909-1910 2 (1): 1-62.

Bedot M. 1917. Le genre Antennella. Revue suisse de Zoologie 25 (5): 111-129.

Bedot M. 1921a. Notes systématiques sur les Plumularides. 2e partie. Revue suisse de Zoologie 29 (1): $1-40$.

Bedot M. 1921b. Hydroïdes provenant des campagnes des Yachts Hirondelle et Princesse-Alice (18871912). Résultats des Campagnes scientifiques accomplies sur son Yacht par Albert Ir Prince souverain de Monaco 60: 1-74.

Billard A. 1911. Note préliminaire sur les espèces nouvelles de Plumulariidae de l'Expédition du Siboga. Archives de Zoologie Expérimentale et Générale (5) 8: 62-71.

Billard A. 1913. Les hydroïdes de 1'Expédition du Siboga. I. Plumulariidae. Siboga-Expeditie 7a: 1-115.

Briggs E.A. \& Gardner V.E. 1931. Hydroida. Scientific Reports of the Great Barrier Reef Expedition 1928-29 4 (6): 181-196.

Calder D.R. 1983. Hydroida from the estuaries of South Carolina, USA: families Sertulariidae and Plumulariidae. Proceedings of the Biological Society of Washington 96 (1): 7-28.

Cunningham C.W. \& Buss L.W. 1993. Molecular evidence for multiple episodes of paedomorphosis in the family Hydractiniidae. Biochemical Systematics and Ecology 21: 57-69.

https://doi.org/10.1016/0305-1978(93)90009-G

Darriba D., Taboada G.L., Doallo R. \& Posada D. 2012. jModelTest 2: more models, new heuristics and parallel computing. Nature Methods 9: 772. https://doi.org/10.1038/nmeth.2109

Di Camillo C.G., Bavestrello G., Valisano L. \& Puce S. 2008. Spatial and temporal distribution in a tropical hydroid assemblage. Journal of the Marine Biological Association of the United Kingdom 88 (8): 1589-1599. https://doi.org/10.1017/S0025315408002981

Di Camillo C.G., Puce S. \& Bavestrello G. 2009. Macrorhynchia species (Cnidaria: Hydrozoa) from the Bunaken Marine Park (North Sulawesi, Indonesia) with a description of two new species. Italian Journal of Zoology 76 (2): 208-228. https://doi.org/10.1080/11250000802182018

Di Camillo C.G., Bo M., Puce S. \& Bavestrello G. 2010. Association between Dentitheca habereri (Cnidaria: Hydrozoa) and two zoanthids. Italian Journal of Zoology 77 (1): 81-91.

https://doi.org/10.1080/11250000902740962

Galea H.R. 2007. Hydroids and hydromedusae (Cnidaria: Hydrozoa) from the fjords region of southern Chile. Zootaxa 1597: 1-116.

Galea H.R. 2008. On a collection of shallow-water hydroids (Cnidaria: Hydrozoa) from Guadeloupe and Les Saintes, French Lesser Antilles. Zootaxa 1878: 1-54. https://doi.org/10.11646/zootaxa.1878.1.1

Galea H.R. 2010. Additional shallow-water thecate hydroids (Cnidaria: Hydrozoa) from Guadeloupe and Les Saintes, French Lesser Antilles. Zootaxa 2570: 1-40. https://doi.org/10.11646/zootaxa.2570.1.1 
Galea H.R. 2020. Aglaopheniid hydroids (Cnidaria: Hydrozoa: Aglaopheniidae) from off New Caledonia collected during KANACONO and KANADEEP expeditions of the French Tropical Deep-Sea Benthos Program. European Journal of Taxonomy 615: 1-47. https://doi.org/10.5852/ejt.2020.615

Galea H.R. \& Schuchert P. 2019. Some thecate hydroids (Cnidaria: Hydrozoa) from off New Caledonia collected during KANACONO and KANADEEP expeditions of the French Tropical Deep-Sea Benthos Program. European Journal of Taxonomy 562: 1-70. https://doi.org/10.5852/ejt.2019.562

Galea H.R., Ferry R. \& Bertot J.M. 2012. Medusoids in the life cycle of Dentitheca dendritica (Nutting, 1900 ) and Nemalecium gracile sp. nov. (Cnidaria: Hydrozoa). Zootaxa 3527: 43-54.

https://doi.org/10.11646/zootaxa.3527.1.3

Galea H.R., Di Camillo C.G., Maggioni D., Montano S. \& Schuchert P. 2018. A reassessment of Halopteris polymorpha (Billard, 1913) (Cnidaria: Hydrozoa), with descriptions of three new species. Revue suisse de Zoologie 125 : 21-59. https://doi.org/10.5281/zenodo.1196007

Hirohito, Emperor of Japan. 1969. Some hydroids from the Amakusa Islands. Publications of the Biological Laboratory, Imperial Household, Tokyo 9: 1-32.

Hirohito, Emperor of Japan. 1974. Some hydrozoans of the Bonin Islands. Publications of the Biological Laboratory, Imperial Household, Tokyo 11: 1-55.

Hirohito, Emperor of Japan. 1983. Hydroids from Izu Ôshima and Niijima. Publications of the Biological Laboratory, Imperial Household, Tokyo 6: 1-83.

Hirohito, Emperor of Japan. 1995. The hydroids of Sagami Bay. II. Thecata. Publications of the Biological Laboratory, Imperial Household, Tokyo 1-244.

Inaba M. 1892. Hydroidea obtained in Shima. Dobutsugaku Zasshi (Zoological Magazine, Tokyo) 4 (47): 345-351.

Jäderholm E. 1903. Aussereuropäische Hydroiden im schwedischen Reichsmuseum. Arkiv för Zoologi 1: $259-312$.

Katoh K. \& Standley D.M. 2013. MAFFT multiple sequence alignment software version 7: improvements in performance and usability. Molecular Biology and Evolution 30: 772-780.

https://doi.org/10.1093/molbev/mst010

Kirkendale L. \& Calder D.R. 2003. Hydroids (Cnidaria: Hydrozoa) from Guam and the Commonwealth of the Northern Marinas Islands (CNMI). Micronesica 35/36: 159-188.

Leloup E. 1937. Hydroidea, Siphonophora, Ceriantharia. I. - Hydropolypes. In: Résultats scientifiques des croisières du navire-école belge «Mercator». Mémoires du Muséum d'Histoire naturelle de Belgique (2) 9: 91-121.

Maggioni D., Schiavo A., Ostrovsky A.N., Seveso D., Galli P., Arrigoni R., Berumen M.L., Benzoni F. \& Montano S. 2020. Cryptic species and host specificity in the bryozoan-associated hydrozoan Zanclea divergens (Hydrozoa, Zancleidae). Molecular Phylogenetics and Evolution 151: 106893. https://doi.org/10.1016/j.ympev.2020.106893

Maronna M.M., Miranda T.P., Peña Cantero Á.L., Barbeitos M.S. \& Marques A.C. 2016. Towards a phylogenetic classification of Leptothecata (Cnidaria, Hydrozoa). Scientific Reports 6: 1-23. https://doi.org/10.1038/srep18075

Migotto A.E. 1996. Benthic shallow-water hydroids (Cnidaria, Hydrozoa) of the coast of São Sebastião, Brazil, including a checklist of Brazilian hydroids. Zoologische Verhandelingen, Leiden 306: 1-125. Available from https://www.repository.naturalis.n1/document/148871 [accessed 12 Aug. 2020]. 
Migotto A.E. \& Marques A.C. 1999. Redescription of Dentitheca bidentata (Cnidaria: Hydrozoa, Plumulariidae), with notes on its life cycle. Journal of Natural History 33: 949-960.

https://doi.org/10.1080/002229399300029

Millard N.A.H. 1957. The Hydrozoa of False Bay, South Africa. Annals of the South African Museum 43 (4) (6): 173-243.

Millard N.A.H. 1962. The Hydrozoa of the south and west coasts of South Africa. Part I. The Plumulariidae. Annals of the South African Museum 46 (11): 261-319.

Millard N.A.H. 1975. Monograph on the Hydroida of southern Africa. Annals of the South African Museum 68: 1-513.

Millard N.A.H. 1980. The South African Museum's Meiring Naude cruises. Part 11. Hydroida. Annals of the South African Museum 82 (4): 129-153.

Miller M.A., Pfeiffer W. \& Schwartz T. 2010. Creating the CIPRES Science Gateway for inference of large phylogenetic trees. Proceedings of the Gateway Computing Environments Workshop. https://doi.org/10.1109/GCE.2010.5676129

Moura C., Lessios H., Cortés J., Nizinski M.S., Reed J., Santos R.S. \& Collins A.G. 2018. Hundreds of genetic barcodes of the species-rich hydroid superfamily Plumularioidea (Cnidaria, Medusozoa) provide a guide toward more reliable taxonomy. Scientific Reports 8: 17986.

https://doi.org/10.1038/s41598-018-35528-8

Nutting C.C. 1900. American hydroids. Part I. The Plumularidae. Special Bulletin of the United States National Museum 4 (1): 1-285. https://doi.org/10.5962/bhl.title.1327

Nutting C.C. 1905. Hydroids of the Hawaiian Islands collected by the Steamer Albatross in 1902. Bulletin of the United States Fish Commission 23 (3): 931-959.

Nutting C.C. 1927. Report on the Hydroida collected by the United States Fisheries steamer "Albatross" in the Philippine region, 1907-1910. In: Contributions to the biology of the Philippine archipelago and adjacent regions. Bulletin of the United States National Museum 100 (6) (3): 195-242.

Park J.H. 2010. Invertebrate fauna of Korea. Cnidaria: Hydrozoa: Thecatae. Thecates. Flora and Fauna of Korea 4 (1): 1-183.

Peña Cantero A.L., Svoboda A. \& Vervoort W. 1997. Species of Oswaldella Stechow, 1919 (Cnidaria, Hydrozoa) from recent Antarctic expeditions with R.V. Polarstern, with the description of eight new species. Zoological Journal of the Linnean Society 119 (3): 339-388.

https://doi.org/10.1111/j.1096-3642.1997.tb00140.x

Rees W.J. \& Vervoort W. 1987. Hydroids from the John Murray expedition to the Indian Ocean, with revisory notes on Hydrodendron, Abietinella, Cryptolaria and Zygophylax (Cnidaria: Hydrozoa). Zoologische Verhandelingen, Leiden 237: 1-209.

Available from https://www.repository.naturalis.nl/document/148867 [accessed 12 Aug. 2020].

Rho B.J. 1969. Studies on the marine hydroids in Korea (2). Journal of Korean Research Institute for Better Living, Ewha Womans University 2: 161-172.

Ritchie J. 1913. On the invalidity of the hydroid genus Diplopteron Allman. Proceedings of the Royal Physical Society of Edinburgh 19: 6-7.

Ronowicz M., Boissin E., Postaire B., Bourmaud C.A-F., Gravier-Bonnet N. \& Schuchert P. 2017. Modern alongside traditional taxonomy - Integrative systematics of the genera Gymnangium Hincks, 1874 and Taxella Allman, 1874 (Hydrozoa, Aglaopheniidae). PLoS One 12 (4): 1-43.

https://doi.org/10.1371/journal.pone.0174244

Ruthensteiner B., Götz-Nodo R. \& Straube N. 2008. The type material of Hydrozoa described by Eberhard Stechow in the Zoologische Staatssammlung München. Spixiana 31 (1): 3-27. 
GALEA H.R. \& MAGGIONI D., Plumularioid hydroids from off New Caledonia

Ryland J.S. \& Gibbons M.J. 1991. Intertidal and shallow water hydroids from Fiji. II. Plumulariidae and Aglaopheniidae. Memoirs of the Queensland Museum 30 (3): 525-560.

Schuchert P. 1997. Review of the family Halopterididae. Zoologische Verhandelingen, Leiden 309: 1-162. Available from https://www.repository.naturalis.nl/document/149017 [accessed 12 Aug. 2020].

Schuchert P. 2003. Hydroids (Cnidaria, Hydrozoa) of the Danish expedition to the Kei Islands. Steenstrupia 27 (2): 137-256.

Schuchert P. 2013. The status of Plumularia lagenifera Allman, 1885 (Cnidaria, Hydrozoa) and related species. Zootaxa 3613 (2): 101-124. https://doi.org/10.11646/zootaxa.3613.2.1

Schuchert P. 2014. High genetic diversity in the hydroid Plumularia setacea: A multitude of cryptic species or extensive population subdivision? Molecular Phylogenetics and Evolution 76: 1-9. https://doi.org/10.1016/j.ympev.2014.02.020

Schuchert P. 2015. On some hydroids (Cnidaria, Hydrozoa) from the Okinawa Islands, Japan. Revue suisse de Zoologie 122 (2): 325-370. https://doi.org/10.5281/zenodo.30004

Stechow E. 1909. Hydroidpolypen der japanischen Ostküste. I. Teil: Athecata und Plumularidae. Abhandlungen der Königlich Bayerischen Akademie der Wissenschaften, Supplementband zu den Abhandlungen der Mathematisch-naturwissenschaftlichen Klasse 1 (6): 1-111.

Stechow E. 1913. Hydroidpolypen der japanischen Ostküste. II. Teil: Campanularidae, Halecidae, Lafoeidae, Campanulinidae und Sertularidae, nebst Ergänzungen zu den Athecata und Plumularidae. In: Doflein F. (ed.) Beiträge zur Naturgeschichte Ostasiens. Abhandlungen der Königlich Bayerischen Akademie der Wissenschaften, Supplementband zu den Abhandlungen der Mathematischnaturwissenschaftlichen Klasse 3 (2): 1-162. https://doi.org/10.5962/bhl.title.11621

Stechow E. 1920. Neue Ergebnisse auf dem Gebiete der Hydroidenforschung. Sitzungsberichte der Gesellschaft für Morphologie und Physiologie in München 31: 9-45.

Stechow E. 1923a. Die Hydroidenfauna der Japanischen Region. Journal of the College of Science of the Imperial University of Tokyo 44 (8): 1-23.

Stechow E. 1923b. Zur Kenntnis des Hydroidenfauna des Mittelmeeres, Amerikas und anderer Gebiete. II. Teil. Zoologische Jahrbücher 47 (1): 29-270.

Stechow E. 1923c. Neue Hydroiden der Deutschen Tiefsee-Expedition, nebst Bemerkungen über einige andre Formen. Zoologischer Anzeiger 56 (1-2): 1-20.

Stechow E. 1925. Hydroiden von West- und Südwestaustralien nach den Sammlungen von Prof. Dr. Michaelsen und Prof. Dr. Hartmeyer. Zoologische Jahrbücher, Abteilung für Systematik, Geographie und Biologie der Tiere 50 (2): 191-270.

Tseng L.C., Wu C.H., Twan W.H., Tang Z.C. \& Hwang J.S. 2014. Hydroids (Cnidaria, Hydrozoa) from marine environments in Taiwan. Zoological Studies 53: 29. https://doi.org/10.1186/s40555-014-0029-z

Van Gemerden-Hoogeveen G.C.H. 1965. Hydroids of the Caribbean: Sertulariidae, Plumulariidae and Aglaopheniidae. Studies on the Fauna of Curaçao and other Caribbean Islands 84: 1-87.

Vannucci M. 1949. Hydrozoa do Brasil. Boletin de Faculdade de Filosofia, Ciências e Letras da Universidade do São Paulo, Zoologia 14: 219-266.

https://doi.org/10.11606/issn.2526-4877.bsffclzoologia.1949.129110

Vannucci M. 1950. Resultados cientificos do cruzeiro "Baependi" e do "Vega" à Isla da Trindade. Boletim do Instituto Paulista de Oceanogrografia 1 (1): 81-96.

https://doi.org/10.1590/S0100-42391950000100007 
Vannucci M. 1951. Distribuição dos Hydrozoa até agora conhecidos nas costas do Brasil. Boletim do Instituto Paulista de Oceanogrografia 2 (1): 105-124. https://doi.org/10.1590/S0100-42391951000100004

Van Praët M. 1979. Les types de polypes d'Hydraires conservés au Muséum national d'Histoire naturelle de Paris. Bulletin du Muséum national d'histoire naturelle de Paris (4) 1, section A (4): 871-940.

Vervoort W. 1966. Bathyal and abyssal hydroids. Scientific Results of the Danish Deep-Sea Expedition 1950-1952. Galathea Report 8: 97-174.

Vervoort W. 1967. The Hydroida and Chondrophora of the Israel South Red Sea Expedition, 1962. Israel South Red Sea Expedition 1962 25: 18-54.

Vervoort W. 1968. Report on a collection of Hydroida from the Caribbean region, including an annotated checklist of Caribbean hydroids. Zoologische Verhandelingen, Leiden 92: 1-124. Available from https://www.repository.naturalis.nl/document/148995 [accessed 12 Aug. 2020].

Vervoort W. \& Watson J.E. 2003. The marine fauna of New Zealand: Leptothecata (Cnidaria: Hydrozoa) (thecate hydroids). NIWA Biodiversity Memoir 119: 1-538.

Available from https://archive.org/details/niwabiodiversitymemoir01192003 [accessed 12 Aug. 2020].

Von Schenck A. 1965. Die Kormentektonik der Plumulariiden (Coelenterata, Hydrozoa). Revue suisse de Zoologie 72 (44): 855-1021. https://doi.org/10.5962/bhl.part.75672

Watson J.E. 1997. The hydroid fauna of the Houtman Abrolhos Islands, Western Australia. In: Wells F.E. (ed.) The Marine Flora and Fauna of the Houtman Abrolhos Islands, Western Australia: 503-546. Western Australian Museum, Perth.

Watson J.E. 2000. Hydroids (Hydrozoa: Leptothecata) from the Beagle Gulf and Darwin Harbour, northern Australia. The Beagle, Records of the Museum and Art Galleries of the Northern Territory 16:1-82. Available from https://www.biodiversitylibrary.org/page/55260920\#page/5/mode/1up [accessed 11 Aug. 2020].

Watson J.E. 2011. New species, new records and redescriptions of thecate hydroids (Cnidaria: Hydrozoa: Leptothecata) from Southern Australia. Zootaxa 3122 (1): 1-36. https://doi.org/10.11646/zootaxa.3122.1.1

Yamada M. 1959. Hydroid fauna of Japanese and its adjacent waters. Publications of the Akkesi Marine Biological Station 9: 1-101.

Zietara M.S., Arndt A., Geets A., Hellemans B. \& Volckaert F.A. 2000. The nuclear rDNA region of Gyrodactylus arcuatus and G. branchicus (Monogenea: Gyrodactylidae). Journal of Parasitology 86: 1368-1373. https://doi.org/10.1645/0022-3395(2000)086[1368:TNRROG]2.0.CO;2

Manuscript received: 25 April 2020

Manuscript accepted: 14 July 2020

Published on: 26 August 2020

Topic editor: Rudy C.A.M. Jocqué

Desk editor: Kristiaan Hoedemakers

Printed versions of all papers are also deposited in the libraries of the institutes that are members of the EJT consortium: Muséum national d'histoire naturelle, Paris, France; Meise Botanic Garden, Belgium; Royal Museum for Central Africa, Tervuren, Belgium; Royal Belgian Institute of Natural Sciences, Brussels, Belgium; Natural History Museum of Denmark, Copenhagen, Denmark; Naturalis Biodiversity Center, Leiden, the Netherlands; Museo Nacional de Ciencias Naturales-CSIC, Madrid, Spain; Real Jardín Botánico de Madrid CSIC, Spain; Zoological Research Museum Alexander Koenig, Bonn, Germany; National Museum, Prague, Czech Republic. 